Florida International University FIU Digital Commons

$1-22-1996$

\title{
The effects of the leadership styles of Taiwanese junior college presidents on teacher job satisfaction
}

Ching-San Chiang

Florida International University

DOI: $10.25148 /$ etd.FI14060195

Follow this and additional works at: https://digitalcommons.fiu.edu/etd

Part of the Curriculum and Instruction Commons

\section{Recommended Citation}

Chiang, Ching-San, "The effects of the leadership styles of Taiwanese junior college presidents on teacher job satisfaction" (1996). FIU Electronic Theses and Dissertations. 2163.

https://digitalcommons.fiu.edu/etd/2163 


\section{FLORIDA INTERNATIONAL UNIVERSITY}

Miami, Florida

\section{THE EFFECTS OF THE LEADERSHIP STYLES OF TAIWANESE JUNIOR COLLEGE PRESIDENTS ON TEACHER JOB SATISFACTION}

A dissertation submitted in partial satisfaction of the

requirements for the degree of

DOCTOR OF EDUCATION

in

CURRICULUM AND INSTRUCTION

by

Ching-San Chiang

1996 
To: Dean I. Ira Goldenberg

College of Education

This dissertation, The Effects of the Leadership Styles of the Taiwanese Junior College

Presidents on Teacher Job Satisfaction, written by Ching-San Chiang, having been approved in respect to style and intellectual content, is referred to your judgement.

\author{
Judith J. Slater
}

Paul A. Rendulic

Stephen M Fain, Major Professor

Date of Defense: January 22, 1996

The dissertation of Ching-San Chiang is approved.

Dean I. Ira Goldenberg

College of Education

Dean Richard L. Campbell

Division of Graduate Studies

Florida International University, 1996 
(c) COPYRIGHT 1996 by Ching-San Chiang

All rights reserved 
This dissertation is dedicated to my parents and to my immediate and extended family. 


\section{ACKNOWLEDGMENTS}

I would like to extend my appreciation and gratitude to the many individuals who contributed to this dissertation effort. First, I would like to express my sincere thanks to Dr. Stephen M. Fain, committee chairman, and a great teacher, for the mentoring role he has played in so many areas of my professional life. I would also like to express my appreciation to Dr. Judith J. Slater and Dr. Paul A. Rendulic for the time and effort they expended as committee members and for the many ways they have supported me throughout my doctoral program.

A special expression of gratitude goes out to $\mathrm{Dr}$. Zi-Li Kang for giving me great guidance and encouragement. I would also like to express my appreciation to Liang-Te Hung, President of Chien-Kuo Junior College of Technology and Commerce. Many thanks are due to Professor Hung-Yao Pai and Dr. Chi-Chang Liu for their support of data collection.

Greatest thanks to my father, father-in-law, mother-in-law, my sisters, and brothers for their continued support, encouragement, and contributions. Most of all, I would like to thank my mother, for her inspiration and for guiding me in what to do, and how to do. Last, I thank my wife, Pei-Ling, and my daughters Kathy, Kelly, and Stephanie. Their ongoing support, cooperation, and sacrifice enhanced my doctoral studies. Thank you all. 


\author{
ABSTRACT OF THE DISSERTATION \\ THE EFFECTS OF LEADERSHIP STYLES OF \\ TAIWANESE JUNIOR COLLEGE PRESIDENTS \\ ON TEACHER JOB SATISFACTION \\ by

\section{Ching-San Chiang} \\ Florida International University, 1995 \\ Professor Stephen M. Fain, Major Professor
}

The purpose of this dissertation was to investigate the relationship between the leadership styles of Taiwanese junior college presidents and teacher job satisfaction. The study examined the difference in teachers' perceptions of presidents' leadership style and teachers' job satisfaction, the degree of agreement between teachers' perceptions and presidents' self-perceptions, the difference in leadership style and presidents' age, tenure, school status and size; the difference in job satisfaction and teachers' gender, age, job tenure, education, academic rank, school status, and school size.

Data were obtained from 20 presidents and 282 teachers. The Presidents' Leadership Orientations questionnaire collected data from presidents. The Presidents' Leadership Orientations and Teacher Job Satisfaction questionnaires collected data from teachers. Data were analyzed by t-tests, ANOVA, Chi Square, and Scheffe's test for comparing contrasts. Descriptive analyses yielded means, standard deviations, frequencies, and percentages. All results were tested at the 0.05 level of significance. 
Findings: General job satisfaction was related to number, but not to type, of leadership frame. Teachers' and presidents' perceptions of leadership style used were congruent. Leadership style did not differ with presidents' age, job tenure, school size, or school status. Teacher satisfaction with teaching, school environment, administration/supervision, job remuneration, and promotion differed with school size. Satisfaction with teaching and promotion differed with gender. Satisfaction with teaching, administration/supervision, job remuneration, and promotion differed with academic rank. Satisfaction with school environment differed with supervision/administration and age. Satisfaction with supervision/administration differed with tenure. There was no difference between educational level and any of the satisfaction measures. 


\section{TABLE OF CONTENTS}

CHAPe

CHAPTER I: INTRODUCTION $\ldots \ldots \ldots \ldots \ldots \ldots \ldots \ldots \ldots \ldots \ldots$

Statement of the Problem . . . . . . . . . . . . . . . . . . . . 7

Purpose of the Study $\ldots \ldots \ldots \ldots \ldots \ldots \ldots \ldots \ldots \ldots \ldots \ldots$

The Research Questions $\ldots \ldots \ldots \ldots \ldots \ldots \ldots \ldots \ldots$

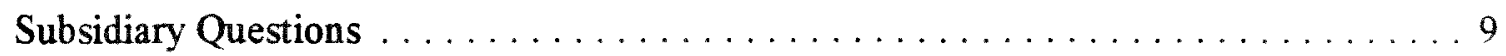

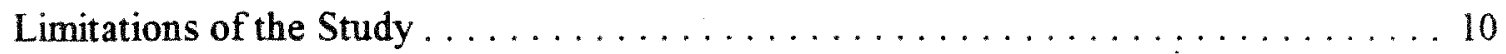

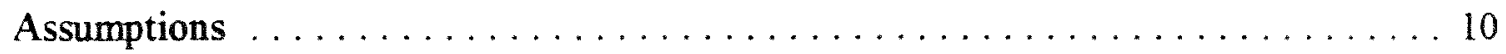

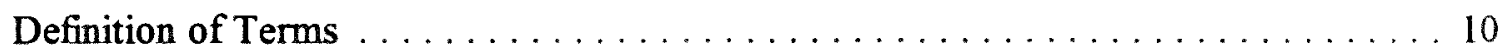

CHAPTER II: REVIEW OF THE LITERATURE $\ldots \ldots \ldots \ldots \ldots \ldots \ldots \ldots$

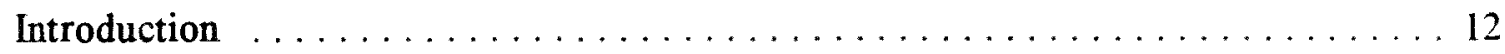

The Theory and Related Study of University Presidents' Leadership Style . . . . . . 12

The Definition of Leadership $\ldots \ldots \ldots \ldots \ldots \ldots \ldots \ldots \ldots \ldots \ldots$

The Development of Leadership Theory . . . . . . . . . . . . 13

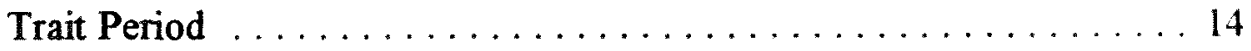

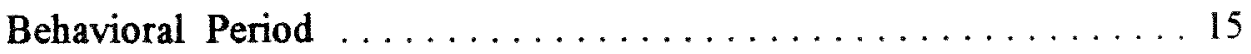

Contingency Period $\ldots \ldots \ldots \ldots \ldots \ldots \ldots \ldots \ldots \ldots \ldots \ldots$

Modem Leadership Theory $\ldots \ldots \ldots \ldots \ldots \ldots \ldots \ldots \ldots$

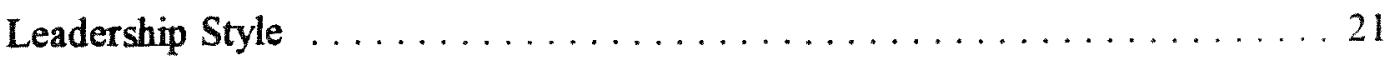

One-Dimensional Leadership Theory $\ldots \ldots \ldots \ldots \ldots \ldots \ldots \ldots \ldots \ldots$

Two-Dimensional Leadership Theory ............... 23

Multiple Frames Leadership Theory $\ldots \ldots \ldots \ldots \ldots \ldots \ldots \ldots$ 
The Theory and Related Literature on Job Satisfaction

The Definition of Job Satisfaction . . . . . . . . . . . . . . . . . 29

The Development of Job Satisfaction Studies . . . . . . . . . . . 32

The Related Theories of Teacher Job Satisfaction ............. 37

Maslow's Hierarchy of Needs Theory . . . . . . . . . . 37

Herzberg's Two-Factor (Motivation-Hygiene) Theory) . . . . . . . , 39

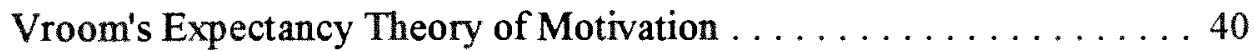

Related Instruments and Their Results $\ldots \ldots \ldots \ldots \ldots \ldots \ldots \ldots \ldots \ldots \ldots \ldots$

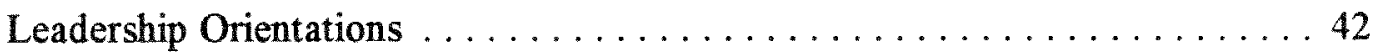

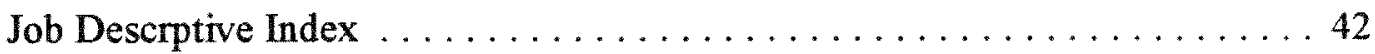

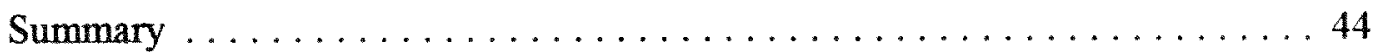

CHAPTER III: RESEARCH METHODOLOGY $\ldots \ldots \ldots \ldots \ldots \ldots \ldots \ldots$

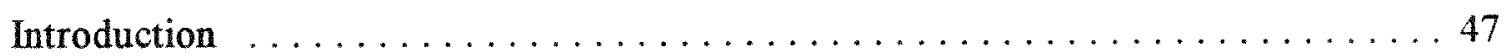

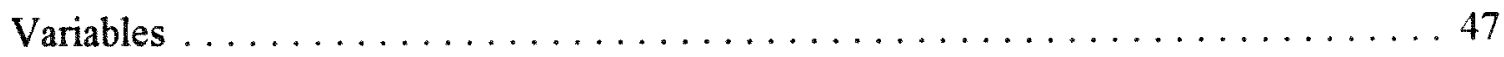

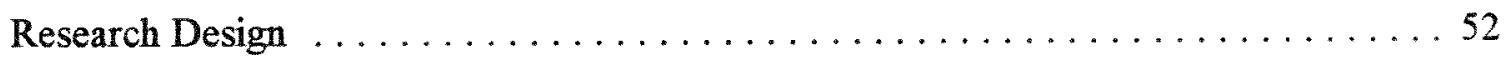

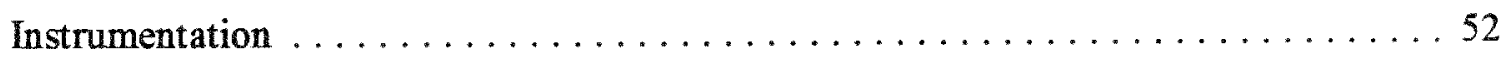

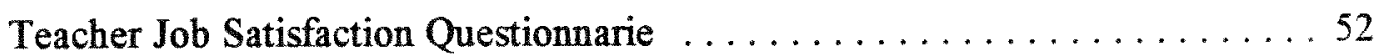

Leadership Orientations Questionnaire $\ldots \ldots \ldots \ldots \ldots \ldots \ldots \ldots$

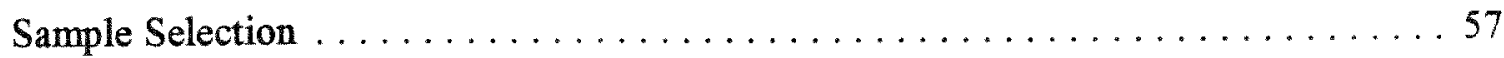

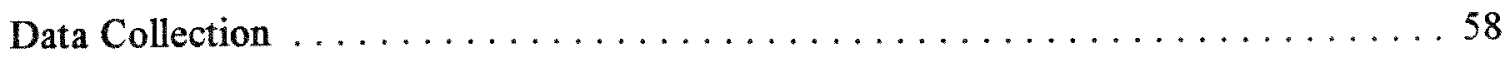

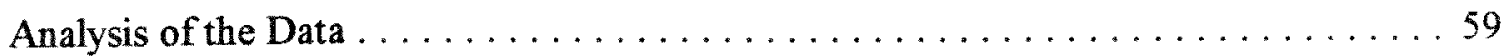




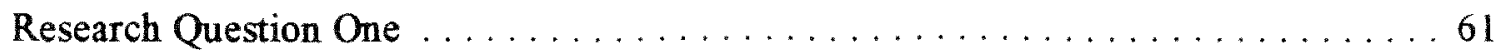

Research Question Two . . . . . . . . . . . . . . . . . . . . 66

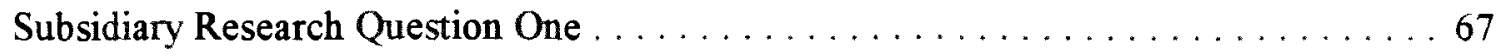

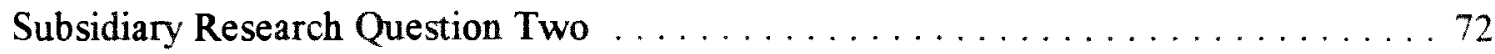

CHAPTER V: SUMMARY, CONCLUSIONS, AND RECOMMENDATIONS $\ldots 87$

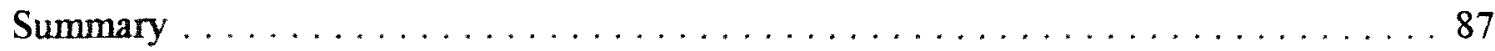

Purpose of the Study $\ldots \ldots \ldots \ldots \ldots \ldots \ldots \ldots \ldots \ldots \ldots$

Review of Pertinent Literature $\ldots \ldots \ldots \ldots \ldots \ldots \ldots \ldots \ldots$. . . . . . 87

Design and Methodology $\ldots \ldots \ldots \ldots \ldots \ldots \ldots \ldots \ldots, \ldots, \ldots$

Research Questions $\ldots \ldots \ldots \ldots \ldots \ldots \ldots \ldots \ldots \ldots \ldots$

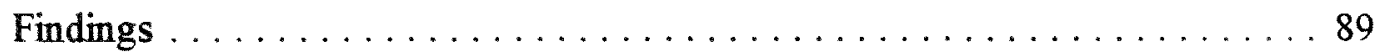

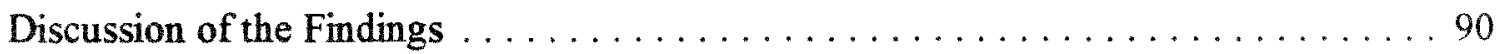

General Job Satisfaction and Leadership Style $\ldots \ldots \ldots \ldots \ldots \ldots \ldots$

Congruence of Perceptions . . . . . . . . . . . . . . . . 92

Leadership Style and Presidents' Demographics . . . . . . . . . . 93

Job Satisfaction and Teacher Demographics . . . . . . . . . . . 93

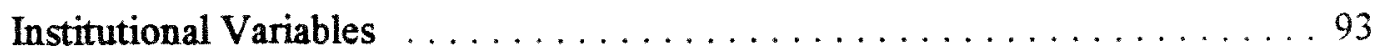

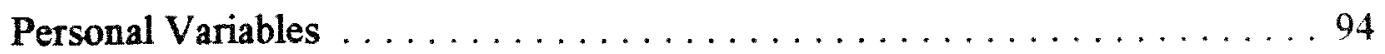

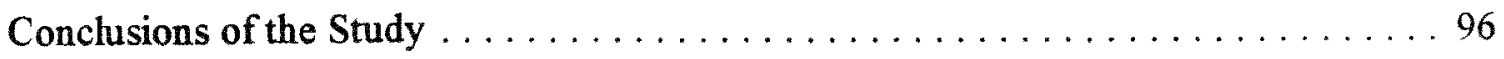

Implications for Research and Practice $\ldots \ldots \ldots \ldots \ldots \ldots \ldots \ldots \ldots \ldots$

Recommendations for Future Research $\ldots \ldots \ldots \ldots \ldots \ldots \ldots \ldots$ 


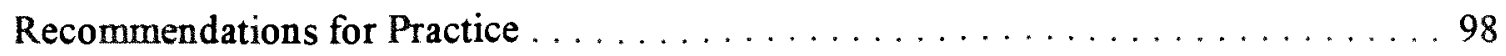

REFERENCES .................................. 101

\section{APPENDICES}

A. Letter of Permission from Vanderbilt University $\ldots \ldots \ldots \ldots \ldots \ldots \ldots$

B. Leadership Orientations (Self) $\ldots \ldots \ldots \ldots \ldots \ldots \ldots \ldots \ldots \ldots \ldots \ldots \ldots \ldots$

C. Leadership Orientations (Other) $\ldots \ldots \ldots \ldots \ldots \ldots \ldots \ldots \ldots \ldots \ldots \ldots$

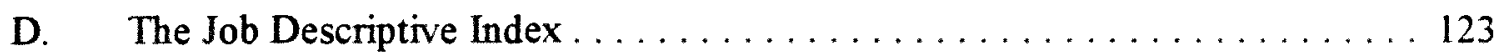

E. President's Leadership Orientations (Presidents'Questionnaire) $\ldots \ldots \ldots 127$

F. President's Leadership Orientations and Teacher Job Satisfaction (Teachers' Questionnaire) ........................ 134

G Letter of Verification . . . . . . . . . . . . . . . . . . . . 144

H. President's Leadership Orientations (Presidents'Questionnaire)

(Chinese Versions) . . . . . . . . . . . . . . . . . . . 146

I. President's Leadership Orientations and Teacher Job Satisfaction (Teachers' Questionnaire) (Chinese Versions) . . . . . . . . . . 151

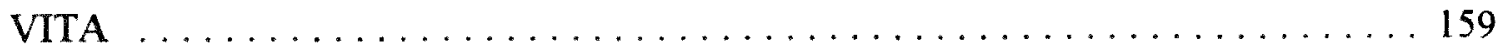




\section{List of Figures}

Figure

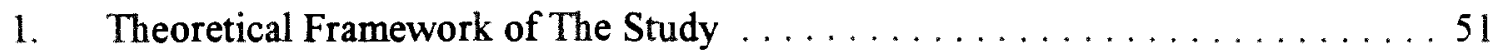

List of Tables

Table

4-1. Demographic Data of Respondents (Teachers) . . . . . . . . . . . . 62

4-2. Demographic Data of Respondents (Presidents) $\ldots \ldots \ldots \ldots \ldots \ldots \ldots$

4-3. How Many Frames Do Presidents Use? (Teachers' Perception) . . . . . . . . 64

4-4. Which Frames Do Presidents Use? (Teachers' Perception) . . . . . . . . . . 64

4-5. Mean, Standard Deviation, and Frequencies of General Job Satisfaction on Which Frames . . . . . . . . . . . . . . . . . 65

4-6. Mean, Standard Deviation, and Frequencies of General Job Satisfaction on How Many Frames $\ldots \ldots \ldots \ldots \ldots \ldots \ldots \ldots$

4-7. Multiple Comparison of General Job Satisfaction on How Many Frames $\ldots \ldots \ldots \ldots \ldots \ldots \ldots \ldots \ldots \ldots \ldots \ldots \ldots \ldots \ldots \ldots \ldots$

4-8. Which Frames Do Presidents Use $\ldots \ldots \ldots \ldots \ldots \ldots \ldots \ldots \ldots \ldots \ldots$

4-9. How Many Frames Do Presidents Use $\ldots \ldots \ldots \ldots \ldots \ldots \ldots \ldots \ldots \ldots$

4-10. T-tests for Which Frames on Presidents' Age, Tenure, and School Status 68

4-10A ANOVA for Which Frame on School Size $\ldots \ldots \ldots \ldots \ldots . \ldots \ldots$

4-11. Presidents' Age on Which Frames (Presidents' Perception) $\ldots \ldots \ldots \ldots, 69$

4-12. Presidents' Tenure on Which Frames (Presidents' Perception) . . . . . . . . . 69 
4-13. Which Frames Do Presidents Use on School Status?

(Presidents' Perception) 70

4-14. Which Frames Do Presidents Use on School Size?

(Presidents' Perception)

4-15. The Mean of How Many Frames the President Uses $\ldots \ldots \ldots \ldots \ldots$. . . . 72

4-16. T-tests for Subscales of Job Satisfaction on School Status . . . . . . . 73

4-17. ANOVA for Subscales of Job Satisfaction on School Size . . . . . . . . . . 74

4-18. Multiple Comparison of Environment on School Size. . . . . . . . . . 75

4-19. Multiple Comparison of Administration Supervision on School Size . . . . . 75

4-20. Multiple Comparison of Job Remuneration on School Size . . . . . . . 75

4-21. Multiple Comparison of Promotion on School Size ............. 75

4-22. T-tests for Subscales of Job Satisfaction on Gender $\ldots \ldots \ldots \ldots \ldots \ldots$

4-23. ANOVA for Subscales of Job Satisfaction on Age . . . . . . . . . . . . 77

4-24. Multiple Comparison of Administration Supervision on Age . . . . . . . 77

4-25. ANOVA for Subscales of Job Satisfaction on Tenure $\ldots \ldots \ldots \ldots \ldots 78$

4-26. Multiple Comparison of Administration Supervision on Tenure . . . . . . 79

4-27. ANOVA for Subscales of Job Satisfaction on Educational Level . . . . . . . 79

4-28. ANOVA for Subscales of Job Satisfaction on Academic Rank . . . . . . . 80

4-29. Multiple Comparison of Teaching on Academic Rank .......... 81

4-30. Multiple Comparison of Administration Supervision on Academic Rank . . . 81

4-31. Multiple Comparison of Promotion on Academic Rank ........... 82

4-32. T-tests for Subscales of Job Satisfaction on Acting Administration Job . . . . 83 
4-33. Summary of Results with T-Test for Subscales of Job Satisfaction on Sex, Administrative Task, and School Status . . . . . . . . 84

4-34. Summary of Results with ANOVA for Subscales of Job Satisfaction on Age, Tenure, Educational Level, Academic, and School Size . . . . . 85 


\section{CHAPTER ONE}

\section{INTRODUCTION}

Taiwan is a mountainous island of 13,885 square miles. Although Taiwan is not rich in natural resources, according to The Central Bank of China, it has US\$100 billion in foreign exchange (World Journal, 1995). Moreover, Taiwan is reputed to be an economic miracle, attracting the attention and interest of people all over the world. What are the major contributors to Taiwan's economic development?

Yung (1985) stated that under an unfavorable natural environment, the development of Taiwan's economy depends mainly on the mobilization and full utilization of its human resources. Smith (1991) stated that this noteworthy economic achievement comes indirectly from successful vocational-technical education and training.

The Taiwanese junior college is a major scholastic institution in the vocational-technical educational system. One of its chief aims is to provide students with practical skills. Junior colleges are the main source of mid-level technical labor supply (Lin, 1992 ). The Taiwan government has made great efforts to develop high technology and improve product quality. Currently, Taiwan government's goal is to be the business center in Asia and the Pacific area (Lin, 1992). This ambitious stance means that Taiwan needs a contingent of middle level technicians. Consequently, Taiwan has charged the junior colleges with more responsibility and demands high levels of performance. 
The development of a nation is influenced by the learning effectiveness of its students, the future leaders of the nation. Teachers are the conduit of intellectual acquisition; their performance influences the learning effectiveness of students ( $\mathrm{Wu}$, 1992). Teachers are in a unique position to help meet the labor needs of the nation as well as the needs of individual students (Chu, 1993). In order to improve the educational performance of students, a school must first raise the educational standards and instructional abilities of its teachers $(\mathrm{Wu}, 1992, \mathrm{p} .181)$. Therefore, teacher effectiveness must be considered the foundation of school effectiveness.

Sonpon (1984) suggested that teacher satisfaction depends on positive relationships among students, fellow teachers, and school administrators. Cooperation, communication, recognition, and participation help nurture and sustain such relationships. The concept of job satisfaction is particularly intriguing because it is an end in itself; that is, job satisfaction is a positive outcome that is highly valued (Jorde, 1984).

The Hawthorne studies (Mayo, 1933) indicated that employees' psychological and personal attributes influence working behavior. These include their feelings about themselves, their capabilities, their interactions with other employees, their communications skills. Social and mental processes, the most crucial of the affective factors, determine employees' job satisfaction and productivity. Perceptions of the extent to which attention is paid to employees, the extent to which supervisors and managers care about their personal well-being, the extent to which they are allowed to socialize with fellow workers affect job satisfaction and productivity. Also, when supervisors 
demonstrate concern through informal means, employees tend to feel their input into the organization is important (Terry, 1960). Ouchi's (1981) Theory Z suggests that bumanized working conditions not only increase productivity and profits, but also increase employee self-esteem. Humanizing factors include informal interactions, recognition of employees' contribution to the organization, pleasant work surrounding, safe work environment, compassionate and understanding supervisors and managers. Ouchi advocates that these factors become ingrained into the culture of the organization so that they become institutionalized, rather than localized to one or a few units.

There is a close relationship between teachers' job satisfaction and teacher performance, relations with students, psychological well-being, and morale (Collmer, 1989; Katz, 1982) Collmer (1989) found that teachers who were satisfied with their jobs performed better, were less likely to be absent, and appeared to care more for their students. Teacher job satisfaction closely relates to teacher anxiety, absenteeism, and job persistence (Katz, 1982). Redefer (1959) suggested that teachers with high job satisfaction not only have better social relationships with colleagues or supervisors but also rarely tire of work or rarely have feelings of depression. Teachers with high job satisfaction show more positive attitudes towards doing research, improving teaching skills, joining educational associations or activities, and pursuing teaching as a lifelong career. Smith (Collmer, 1989) pointed out that job dissatisfaction produces low morale, higher absenteeism, and inept or uncaring teachers. 
Academic leaders and administrators influence teacher attitudes. Specifically, what college presidents do or say can have an impact on teacher self perception (Gordon, Stockard, \& Williford, 1992). Presidents must set the tone for colleges in ways that allow teachers to perceive the presidents' actions and activities as worthwhile and stimulating (Fox, 1986).

The term "leadership" connotes patterns of interpersonal behavior that help a group achieve its objectives (Owens, 1991). Leaders look for potential motives in followers, seek to satisfy higher needs of followers, and function toward the goal of their organization. According to Washington and Watson (1975), the president's vital responsibility is to manage and promote teachers' job satisfaction level for the purpose of attaining the school's educational goals. The functions of management and control and constituency satisfaction are paramount concerns for the educational leader. Researchers have identified a variety of personal characteristics which are associated with leadership effectiveness (McKee, 1991).

Hersey and Blanchard (1988) argued that effective leaders possess the ability to diagnose, adapt, and communicate the core interests of their organization. Yukl (1989) proposed that effective leaders are able "to establish cooperative relationships with followers, characterized by high levels of mutual trust and loyalty" (p. 275). He also maintained that effective leaders recognize relationships among the variety of problems, issues, and opportunities that they encounter. Sashkin (1987) discussed the ability of effective leaders to vitalize or revitalize an organization and create a place where people 
want to contribute their best. Owens (1991) discussed effective leaders' tendency to combine the authority of their position with the power conferred by the group and to identify easily with the followers' needs and expectations.

In recent years, a new line of research on leadership frame preferences has provided additional insight into how frame preferences influence leadership effectiveness. The concept of frames has many synonyms in the social science literature; for example, frames may be referred to as maps, images, schemata, frames of reference, perspectives, orientations, lenses, metaphors, and mindscapes (Bolman \& Deal, 1990, 1991). Bolman and Deal (1991) used the word "frames" to capture the essence of the various vintage points. The authors conceive of frames as "both windows on the world and lenses that bring the world into focus. Frames filter out some things while allowing others to pass through easily. Frames help us to order experience and decide what action to take" (Bolman \& Deal, 1991, p. 11).

Bolman and Deal $(1984,1991)$ developed four frames for understanding organizations and leadership: structural, human resource, political, and symbolic frames. Structural frame describes behavior of leaders who incorporate aspects of the organization's environment and capabilities into the alignment of organization structure and strategy. Human resource frame describes leaders who demonstrate caring, supportive, empowering attributes. Political frame describes the style of leaders who are clear about their agenda and sensitive to the political reality of the internal and external environments of the organization. Symbolic frame describes the style of leaders who use 
symbols and stories to communicate a vision to the stakeholders of the organization (Bolman \& Deal, 1991). Bensimon $(1988,1989)$ studied college presidents using the four frames. They found that multiframe presidents were viewed as more effective than single-frame presidents.

Bensimon (1988), Bolman (1989), and Wimpelberg (1987) found that individuals who relied primarily on the structural frame were particularly likely to be viewed as ineffective leaders. Several lines of recent research support the view that effective leaders rely on multiple frames (Bolman \& Deal, 1991). An interesting issue relates to the correlation between frame and job satisfaction. In other words, is multiframe leadership style of college/university presidents more closely linked to high teacher job satisfaction while single-frame leadership style is more closely linked to low teacher job satisfaction?

There are many studies on educational leadership behavior in Taiwan. Most researchers have grounded their work in such theoretical frameworks as authoritarian, democratic, and laissez-faire styles, as developed by Lewin, Lippit, and White (1971). Additionally, the Leader Behavior Description Questionnaire (LBDQ) (Silver, 1983), developed at Ohio State University, has been widely adopted in leadership study and research in Taiwan. The popularity of the LBDQ and the framework of Lewin and his colleagues is attributed to their efficacy which has been assessed through many empirical investigations (Bass, 1981; Silver, 1983). On the other hand, this researcher was unable to uncover evidence of application of Bolman and Deal's four frame leadership orientation 
theory to the study of Taiwanese leaders. This orientation could provide further insight into leadership in the Taiwanese culture.

As indicated by Kuo (1995), in the past five years, the Taiwanese educational system has experienced a radical change. University laws were revised to allow for shared power in central government and for campus democratization. Some presidents of the National University were "elected", rather than "appointed". Gradually, parents and members of the society at large made more complicated demands on educational institutions. Teachers were under tremendous pressure. They had never before protested societal demands. But now they protested because parents and communities at large demanded more of teachers and of the schools. Campus humanization, democratization, diversification, science, and internationalization became the norm (Kuo, 1995). These new trends may have influenced presidents' leadership behavior, teachers' job satisfaction, and the relationships between presidents' leadership behavior and teachers' job satisfaction. It is therefore beneficial to investigate the relationships within the frame of reference, as defined by Bolman and Deal (1991).

\section{Statement of the Problem}

Given the radical changes in various aspects of Taiwan's economic and social circumstances, there is an urgent need for changes in colleges and their leaders ( Lin, 1992). As the major scholastic institution for meeting Taiwan's vocational and technical education requirements, junior colleges and their presidents are particularly challenged to 
motivate teachers to perform their tasks with enthusiasm, bearing in mind the impact of their work on Taiwan's economic and social development. Leaders, including junior college presidents who are successful in this endeavor are likely to be versatile, artistic, and resourceful. Several lines of recent research support the view that these qualities require a diversity of outlooks or frames (Bolman \& Deal, 1991; 1994).

Bensimon $(1988,1989)$ found that multiframe college presidents were considered more effective than single-frame presidents. Owens (1991) proposed that the concept of leadership effectiveness has much to do with the motivation of followers, implying that effective leadership is marked by followers' compliance with leader's wishes and desires. This study focused on whether multiframe presidents support teachers with higher job satisfaction than do single-frame presidents. Stated another way: Is job satisfaction of teachers under the leadership of multiframe presidents higher than job satisfaction of teachers under the leadership of single-frame presidents? These are the issues the study aims to address.

\section{Purpose of the Study}

The purpose of this study was to gain a better understanding of the relationship between the leadership style of the Taiwanese junior college presidents and teacher job satisfaction. Bolman and Deal's (1991) multiple frames model were used to investigate the relationship. The following questions guided the research. 
1. What is relationship between teachers' perception of their presidents' leadership style frame and teachers' general job satisfaction? This study operationalized teachers' perception of leadership frames as the number and type of frames used by their presidents. Thus two subquestions here are how many frames each president used and which frame or combination of frames were used.

2. What is the degree of agreement between teachers' perception of presidents' frame and presidents' self perception?

\section{Subsidiary Questions}

1. Does the leadership style of junior college presidents differ significantly with school status, size, and president's age, and job tenure?

2. Do teachers' perceptions of job satisfaction vary significantly with teachers' gender, age, job tenure, educational background, academic position, administrative task, school status, and school size?

\section{Limitations of the Study}

The study has the following limitations: 1) Data are collected for only the 1995-96 academic year. 2) This study is limited to the population of approximately 14,607 full time Taiwanese junior college teachers. Any generalization of the results of this study beyond this population must be done with caution. 3) The study is confined to the presidents' 
self-perception of leadership behavior, teachers' self-perception of job satisfaction, and teachers' perception of presidents' leadership behavior. 4) It is assumed that the subjects of this study would complete all survey items accurately and according to their perceptions of the facts surrounding those items. However, some responses may be based on respondents' preference, rather than on facts.

\section{Assumptions}

The researcher assumes that: 1) Teachers and presidents will answer the survey questions objectively and truthfully. 2) The integrity of the instruments, including reliability and validity, are maintained in the Chinese translation.

\section{Definition of Terms}

Job satisfaction: describes the feelings workers have about their jobs or job experiences in relation to previous experiences, current expectations, or available alternatives (Balzer et al., 1990).

Junior colleges: classified as national, provincial/city, and private junior colleges in Taiwan R.O.C., provide education in applied or practical sciences and technology. The length of education can be two, three, or five years. Two and three-year junior colleges admit senior vocational or high school graduates; five-year junior colleges admit junior high school graduates. Night or evening programs require at least one more year of study than do equivalent day programs (Ministry of Education, 1994). 
Presidents' leadership style: This refers to style as defined in the "Four Frames

Research" by Bolman and Deal (1991). The four frames are structural frame, human resource frame, political frame, and symbolic frame. The research issue revolves around the number of frames a president uses as perceived by presidents themselves and by teachers. The frames translate into four leadership styles: one-frame style, two-frame style, three-frame style, and four-frame style. 


\section{CHAPTER TWO \\ REVIEW OF THE LITERATURE}

Introduction

This study centers around efforts to understand the relationship between leadership style and job satisfaction. The literature review has three components. Part one defines the concept of leadership, examines the evolution of leadership theories, and discusses leadership styles. Part two reviews selected theories of motivation and job satisfaction. Part three discusses the survey instruments and their use.

The Theory and Related Study of University Presidents' Leadership Style The Definition of Leadership

Leadership is one of the most fascinating topics in organizational behavior (Owens, 1991), and, at the same time, a notoriously slippery concept that has produced literally hundreds of definitions in the literature. Owens (1991) proposed that those definitions have two common facets: (1) Leadership is a function of groups, not individuals. Individuals are assigned leadership status, but leadership occurs onty in the interacting processes of two or more persons. In the interacting process, one person is able to induce others to think and behave in desired ways. (2) Leadership involves the intentional exercise of influence on the behavior of others. The essence of leadership is in the distinctive relationships between leaders and followers. 
Burns (1978) described leadership by looking at examples of two types of leaders or leadership styles: transactional and transformational. The "transactional" leader understands the give and take of leadership. Transactional leadership occurs when one person takes the initiative in making contact with others for the purpose of making valued exchanges. This type of leader attracts followers because of the ability to do something of benefit for the follower. In return, the follower performs those actions which are beneficial to the leader. A kind of contract ensues. The leader's and followers' purposes are related, at least to the extent that the purposes stand within the bargaining process and can be advanced by maintaining that process. But beyond this, the relationship between leader's and followers' purpose is weak. The bargainers have no enduring purpose that holds them together. Skillful leaders use these transactions to benefit the organization, as well as to enhance their leadership position.

"Transformational" leadership occurs when one or more persons engage with others in such a way that leaders and followers raise one another to higher levels of motivation and morality. Power bases are linked not as counterweights but as mutual support for common purpose. These two types of leadership are crucial to an overall understanding of leadership in any social setting (Jacobs, 1993).

\section{The Development of Leadership Theory}

All discussion of leadership before this century was nonempirical; discussion ensued when Lao-tzu and Confucius contributed their thoughts on the subject more than 
2,000 years ago (Bolman \& Deal, 1994). Modern day discussion is reflected in the "Great Man Theory of Leadership" and the "Zeitgeist Theory" (Lo, 1989). Hypothesizing that great leaders are born, not made, "Great Man" theorists attempted to identify specific characteristics inherent in leaders (Greenlee, 1992). The "Zeitgeist" theorists proposed that leader emergence depended on natural succession of circumstances and events or happened by chance, rather than through individual-specific characteristics; that is, circumstance, chance, and events signal the development of leaders (Huang, 1989, p.370). The foundation of both theories is in historical and philosophical research; the theories are not grounded in scientific or empirical research. More recent stages of scientific and empirical leadership research could be divided into three periods: (a) the Trait Period (1910 to World War II), (b) the Behavioral Period (World War II to the 1960s), (c) the Contingency Period (1960s to the present) (Chemers, 1984). Each period will be discussed in turn.

\section{Trait Period}

Proponents of trait theory considered leader traits or characteristics the key to leadership effectiveness. They theorized that possession of ideal traits results in successful leadership (Huang, 1989). Trait theory focuses on individual personality, physical, or behavioral traits of leaders in attempts to identify those characteristics or patterns that are unique to leaders as contrasted with nonleaders (Alfonso,et al, 1981). This approach implies that leadership traits could be inherent and transferable from one situation to 
another (Huang, 1989). The results of this approach have not been successful (Huang, 1989). Stogdill (1974), a principal investigator of the trait approach, concluded that there are no specific traits which guarantee leadership success. He did, however, find five sets of characteristics consistently associated with leadership success: capacity (manifested through intelligence and judgment), achievement (manifested as scholarship and knowledge), responsibility (manifested as dependability and persistence), participation (manifested through activity and cooperation), and status (manifested as socioeconomic position and popularity).

Researchers have been unable to isolate a definitive list of leadership traits. As early as 1938, Stogdill deliberated on the issue. He argued that leadership status is not obtained by possessing specific traits, but by the pattern of personal attributes, activities, and goals of a group of persons. He concluded that participating in group activities and showing the ability of achieving the goals of the group have more to do with gaining leadership status than some combination of traits (Stogdill, 1938). It was partly in response to the seeming inconclusiveness of "trait" research that researchers began to study what leaders did (i.e., their behaviors) rather than on who they were and what traits they possessed.

\section{Behavioral Period}

The behavioral theory was initiated by the research at Iowa State University in the $1930^{\prime}$ s, and continued by scholars at the University of Michigan and Ohio State University 
(Wu, 1991). The research focus of behavioral theory is a set of leader behaviors which affects the group. Owens (1991) pointed out that leaders help groups accomplish their tasks and develop appropriate internal arrangements for productive interaction.

Behavioral theories focus on a combination of personal and situational variables or on the interaction between the expectations and perceptions of leaders and followers within differing organizational conditions (Keith \& Girling, 1991).

The behavioral approach counters the hypothesis that some men are born leaders, and that neither training, experience, nor conditions can materially affect leadership skills (Fiedler, 1967). Along with other behaviorists, Fiedler argued that leaders can be trained. He suggested that the most effective way to train leaders is by managerial rotation that provides them with a base of experience on which to draw. This theoretical approach supports the notion that almost every manager in an organization can perform effectively in a leadership role.(Keith \& Girling, 1991).

Behavioral research gives rise to several important implications. Some examples are: leadership is multidimensional, effective leadership behavior varies according to the situation, leadership skills can be taught. However, like trait research, behavioral theories have failed to provide specific guidelines that can be used to identify leaders. Some studies have been criticized for being too simplistic, for being inapplicable to a wide variety of situations, and for relying on questionnaires to measure leadership effectiveness (Baird, Post, \& Mahon, 1990). 
The implications of research on trait and behavioral theories of leadership led to the conclusion that there is no one best approach to understanding leadership. Successful leadership may be determined by certain leadership traits or behaviors, by the fit among traits, behavior, and followers' needs and characteristics; by situational factors and characteristics (Baird, Post, \& Mahon, 1990).

\section{Contingency Period}

Contingency theory defines good leadership as the ability to match the right leadership style to the situation (Keith \& Girling, 1991). Hersey and Blanchard (1977) described leadership as the function of three variables: leader (1), followers (f), and situation (s) [i. e. $\mathrm{L}=(\mathrm{l}, \mathrm{f}, \mathrm{s})$ ]. Therefore, leadership effectiveness is influenced by a leader's characteristics, situational factors, leader behavior or style, situational features, and the interaction of the individual and the situation. Contingency theory is the synthesis of trait and behavioral approaches to leadership; it is a research orientation that combines both trait and behavioral factors (Lui, 1986). The three major situational theories include Contingency Theory by Fiedler (1967), Path-Goal Theory by House (House \& Mitchell, 1974), and the Three-Dimension Theory by Reddin (Owens, 1991).

Fiedler's (1967) Contingency Theory deals with the interaction of position power, task structure, and leader-member relations. A prime criticism of Fiedler's model is that there is no conceptual basis for explaining leader effectiveness (Sashkin, 1988). Sashkin 
observed that situational approaches seem to work weakly for clear reasons or modestly well for very unclear reasons. Therefore, success is unpredictable.

The Path-Goal Theory (House \& Mitchell, 1974) suggests that it is necessary for a leader to influence the followers' perception of work goals, self-development goals, and paths to goal attainment. The foundation for the model was the expectancy motivation model.

Reddin's (1970) 3-D Theory of leadership assumes that leadership cannot be defined in such terms as the leader's behavior or activity, but can be understood only in terms of leadership effectiveness: that is, the extent to which managers achieve the goals for which their positions are responsible. Like the other two dimensions of leadership, the effectiveness dimension of leadership is not "either-or"; rather, it is a continuous scale. Reddin is credited with contributing the effectiveness dimension to the conceptualization of leadership (Owens, 1991).

\section{Modern Leadership Theory}

In 1981 and 1982, organizational studies dramatically shifted, following the publication of two books. The first of these, William Ouchi's Theory $Z$, appeared in 1981 . Published when American corporate managers were groping for solutions to their difficulties in meeting Japanese competition, Theory $Z$ compared and contrasted the management styles used in the two nations. Ouchi, a Japanese-American, found that Japanese management practices were quite different from American practices, and that 
some Japanese practices could be profitably adopted by American corporations. Taking his cue from McGregor's (1960) Theory X - Theory Y, Ouchi named his approach Theory $Z$, to suggest a new alternative (Owens, 1991).

Theory $Z$ points out the differences between Japanese and American management practices, especially those behavioral aspects characterized by McGregor's Theories X and $Y$. The whole focus of theory $Z$ is on organizational culture. The theory proposes that the entire organization has a distinctive culture and managers and employees can determine how the organization's culture is shaped.

Ouchi (1981) argued that Japanese managerial practices were responsible for Japan's successful economic turn. American managers and researchers became quite interested in such practices as quality circles, participative management, innovativeness, creativity, total quality management, flexible work teams, and decentralization that characterize the Japanese management system. These behavioral aspects of management indicated that workers should be treated as individuals with their own rights and interests. They are valuable organizational resources that must be managed with care for the benefit of the organization and for the individual (Baird, Post, \& Mahon, 1990; Trice \& Beyer, 1993).

Owens (1991) proposed that such research emphasized the need for three additional forms of leadership in the educational organization, if the educational organization wants to move from competence to excellence: educational, symbolic, and cultural leadership. Educational leadership focuses on determining and addressing 
scholastic, curricular, and teaching problems. Symbolic leadership describes the attributes and behaviors of leaders who communicate purpose, values, and significance to subordinates; and tries to instill a common vision in all members of the organization. Cultural leadership focuses on developing and maintaining a strong organizational culture, where powerful norms unite members and influence the way they perceive one another, their work, and their organization (Owens, 1991).

Bolman and Deal (1991) stated that incomplete maps in either research or practice limit the ability to understand and manage organizations. They proposed that four frames of organizational theory - structural, human resource, political, and symbolic - illuminate a different slice of life in organizations. They integrated the frames into a multidimensional theory and developed a more comprehensive approach to management.

Earlier writers organized administrative competence into three skill areastechnical, human, and conceptual (Ubben \& Hughes, 1992). Sergiovanni (1969) expanded the third area, conceptual skills, into a series of behavioral forces described as educational, symbolic, and cultural. The authors cited here portray the attempts of current leadership researchers to extract and examine concepts and explanations from symbolic, culture, philosophical, and political inquiries and analyses that augment the understanding of leadership effectiveness. 


\section{Leadership Style}

Generally, leaders' behaviors are depicted by their leadership styles; thus, leadership style is the manifestation of the specific behaviors the leader emphasizes. Leadership behavior stimulates organization or group members to attain desired goals (Huang, 1989). To articulate or explain leadership behavior, researchers usually categorize leadership behavior as specific styles or dimensions of styles that reflect configurations of behaviors which distinguish successful and unsuccessful styles for given situations. The following section discusses leadership style research and implications.

\section{One-Dimensional Leadership Theory}

In accordance with McGregor's (1960) Theory X and Theory Y, Gibb (1969) classified leadership styles as defensive and self-adequate. Defensive leaders do not have much confidence in followers. They assume subordinates are naturally lazy, want no responsibility, and, therefore, should be pressured to act and forced to perform their duties. The defensive leader controls communication through continuous advising and strict management.

Students were asked to rate the overall suitability of their education. Thirty-one percent of the current students noted that their engineering technology program were prepared or well prepared for the jobs, while $40.0 \%$ noted they were somewhat prepared, and $26.4 \%$ noted that their engineering technology program were poorly prepared or does not apply. Self-adequate leaders, on the other hand, have a high degree of confidence in 
followers or subordinates and believe subordinates can exhibit self-control, are competent, want responsibility, are loyal, hard working, and have positive attitudes towards their jobs. Self-adequate leadership favors participatory decision-making, open communication, and loose control and management.

One of the most widely applied classifications of leadership styles was developed by Lewin, Lippitt, and White (1939) of the University of Iowa. Taking the political system as the preferred context for assessing the locus of decision-making, the degree of authorization, and the situation of evaluation, the authors categorized leadership style as authoritative, democratic, and laissez faire. To explain, authoritarian leaders determine all policies, techniques, and activities, maintaining autonomy by remaining aloof from followers or subordinates. Group members are greatly dependent on the authoritative leader. They frequently demonstrate aggressive reactions to the leader, are indolent in the leader's absence, require much of the leader's attention, and have little freedom to make suggestions (White \& Lippitt, 1960).

Democratic leaders provide assistance and guidance. Under this style, policies are determined by group discussion, with the leader taking an active role. Group members are free to express their ideas and make suggestions and to engage in work-related conversation. They also maintain their usual levels of productivity in the absence of the leader (White \& Lippitt, 1960).

Laissez-faire leaders do not take an active role in managing or directing their groups. Rather, they leave members free to make individual or group decisions. Group 
members get the leader's initial reaction by asking for and seeking information and structure. This style sometimes gradually leads to apathy, and eventually to chaos and disorganization (Lippitt \& White, 1960).

Research shows that of the three leadership styles, democratic style is the most preferred (Hanson, 1979). Lipham (1968), however, criticized the definition of such classifications as not sufficiently discriminatory to isolate specific, universally acceptable attributes of each style. The classifications can not specify which style is preferred or which style fits given situations and followers. No single classification characterizes all leaders; situational approaches tend to assume that behavior changes usually flows from the top down, when in fact, followers can trigger behavior changes. Also, the interaction of certain environmental, individual, and task-related factors can help determine which style is appropriate and can also influence employee satisfaction and performance (Baird, Post, \& Mahon, 1990; Chiu, Wen-Chung, 1983).

\section{Two-Dimensional Leadership Theory}

Owens (1991) pointed out that although a wide range of possible leader behaviors exists, for the purpose of simplifying discussions on leader behavior, choices could be polarized, as in Theory $\mathrm{X}$ and $\mathrm{Y}$, and in terms of task-oriented and people-oriented styles. Leadership style evidenced by a specific leader is a combination of task-oriented behavior and people-oriented behavior. Some leaders are concerned about productivity and getting the work done; others are concerned about human relationships. 
Most leaders are somewhere between, and show concern for work and concern for relationships, with the best leaders showing a balance in task and people - oriented behaviors (Owens, 1991).

\section{The Study of Leadership of Ohio State University}

In 1945, the Bureau of Business Research of Ohio State University developed a two-dimensional leadership theory. Leadership styles were categorized as "Initiating Structure" and "Consideration". Halpin (1966, p.86) described initiating structure and consideration dimensions as follows: "Initiating structure leaders focus on goal achievement. They define the relationship between their responsibilities and those of their subordinates. They define the structure within which organizational activities take place, set up channels of communication, and initiate work processes."

Consideration leaders are motivated by the need to help subordinates and satisfy their desires. They focus on establishing and maintaining good interpersonal relationships. They also strive to develop trust in and respect for subordinates, and to understand their problems and demands.

Although these two dimensions are independent when analyzed, they could be combined in practice. Based on the high or low intensity of each dimension, four styles could be portrayed by the leader, as follows. High Initiating Structure and Low Consideration: Leaders emphasize goal achievement and put little or no emphasis on the desires of subordinates or on human elements of work. High Initiating Structure and High 
Consideration: Leaders emphasize goal achievement as well as subordinates' needs and desires. Low Initiating Structure and High Consideration: Leaders emphasize the desires of subordinates, but extend little attention to goal achievement. Low Initiating Structure and Low Consideration: Leaders emphasize neither goal achievement nor subordinates' needs and desires (Halpin, 1966).

In summary, the two dimensions, initiating structure and consideration can be combined, and a person's leadership style can be described as varying along high and low initiating structure and consideration. One leader may demonstrate a strong tendency to structure work to get the job done but also spend time and energy managing interpersonal relations. A second manager, concerned about relationships with subordinates, is chiefly interested in maintaining good relations between subordinates and himself. However, he shows little interest in structuring communications or job assignments. A third manager, rather than spending more time either managing the task or the subordinates, balances time between managing relationships and managing work flows and communications. None of the managers in Halpin's study demonstrated a more or less effective leadership style. Each may be effective, depending on the nature of the situation.

\section{The Leadership Study of University of Michigan}

University of Michigan began to study leader behaviors at about the same time as

Ohio State University. The focus of the University of the Michigan study was to determine whether "Production-oriented" and "Employee-oriented" styles were a single 
dimension of leadership. The researchers found two distinct leadership styles, which they defined as follows: Production-oriented: Leaders emphasize goal achievement and techniques and strongly favor planning and production processes. Employee-oriented: Leaders authorize group members to make decisions; they create a better working environment to support the demands of group members. Moreover, leaders pay more attention to the professional growth and development of group members.

In summary, there are four contingency theories of leadership frequently mentioned in the educational literature include Fiedler's Contingency Theory of Leadership, Vroom and Yetton's Normative Contingency Theory, Reddin's 3-Dimensional Theory of Leadership, and Hersey and Blanchard's Situational Theory of Leadership (Owens, 1991). Each of these theories initially incorporated the two dimensions of task and relations, or work and people. Silver (1983) pointed out that research evidence seems to support Halpin's (1966) assertion that both initiating structure and consideration are important behaviors for educational leaders.

\section{Multiple Frames Leadership Theory}

Bolman and Deal $(1984,1991)$ developed four perspectives, or frames, for understanding organizations and leadership: structural frame, human resource frame, political frame, and symbolic frame. Structural leaders incorporate aspects of the organization's environment and capabilities into a powerful alignment of organization structure and organization strategy. Human resource leaders lead through caring, support, 
accessibility, and empowerment. Political leaders are clear about their agenda and sensitive to political reality; they build the alliances needed to move their organization forward. Symbolic leaders use symbols and stories to communicate a vision that builds faith and loyalty among an organization's employees and other stakeholders.

Bolman and Deal grounded the development of the four frames in the assumption that collectively, the frames capture significant possibilities for leadership. However, taken separately, each frame provides partial understanding of leader behavior. Yet individual leaders consistently and persistently engage in those behaviors, adhering to their dominant or preferred frame. Other leader behaviors or frames may be perceived as superficial, unrealistic, or inappropriate when they may be useful or productive in certain situations. For example, a symbolic frame may be useful for instilling organizational or corporate values regarding cooperation and collaboration, while a human resource frame may be useful for building cooperative work teams where caring, support, accountability, empowerment are manifestations of such organization-wide values (Bolman \& Deal, 1991).

Leaders need to understand their own frame and its limits. Ideally, they will also learn to combine multiple frames into a more comprehensive and powerful style. Bolman and Deal (1991) also see frames as tools for action, with every tool possessing particular strengths and limitations. An inappropriate tool can inhibit job completion, while the right tool can facilitate job completion. One or two tools may suffice for very simple jobs, but more complex jobs require more tools. 
The truly effective manager and leader will need multiple tools, the skill to use each tool, and the wisdom to match frames to situations (Bolman and Deal, 1991).

Leaders must use their artistry to articulate and communicate their vision so that followers are also able to see things differently (Martinez, 1989). At the same time, leaders, like artists, must also bring their followers to understand the relationship between what they, the leaders, want, and what followers understand.

Bensimon (1988, 1989) studied college presidents using the four frames. Bensimon found that professors and staff viewed multiframe presidents as more effective than single-frame presidents (Bolman \& Deal, 1991). According to Bolman and Deal (1991, pp.14-16), leaders may use one or more frames as follows:

One frame: A leader may use only one of the four frames - structural, human resource, political, or symbolic.

Two frames: A leader may use any two of the four frames - structural and human resource, structural and political, structural and symbolic, human resource and symbolic, or political and symbolic.

Three frames: A leader may use any three of the four frames in one of these combinations - structural, human resource, and political; structural, human resources, and symbolic; structural, political, and symbolic; or human resource, political, and symbolic.

Four frames: Leader may use all four frames to ensure a rich variety of behaviors that guide their actions and decisions. Using all four frames equips leaders or managers with several options that can be drawn upon to address issues or circumstances that may 
arise. As leaders have many functions and responsibilities to various constituencies within the organization as well as outside, cross utilization of frames provides a powerful source of potential responses.

In the structural frame, for example, the president may match a strategy for improving teacher satisfaction to the structure of the college by setting policies and staff in place to assure a forum for teachers' concerns. In the human resource frame, professional development programs and practices that foster empowerment, participative decision making, and team building could be developed. In the political frame, interdepartmental, inter-unit, and cross level teams (lecturers, assistant, associate, full professors) could be set up to address the concerns of all categories of faculty. In the symbolic mode, an organizational culture with appropriate value system and vision statement could be developed to institutionalize practices that foster and guarantee faculty satisfaction (Bolman \& Deal, 1991, 1994).

Job Satisfaction: Theory and Related Literature

\section{The Definition of Job Satisfaction}

After Hoppock (1935) published Job Satisfaction, management scholars began to pay much attention to employees' mental state. The new research on workplace strain stressed that to increase production efficiency or job accomplishment, employers must not only improve the physical environmental, but they must also concern themselves with employees' work attitude and behavior. 
Following the Hawthorne studies, more and more employers agreed that ensuring employees' satisfaction in their job can encourage changes in work behavior, elevate productivity, and improve product quality (Baird, Post, \& Mahon, 1990). To understand the concept of "Job Satisfaction", the word "Satisfaction" should be clearly defined.

Hsu (1991) pointed out that according to the related literature, job satisfaction involves employees' feelings about or affective reaction to their job. Such affective or psychological reactions can be classified as subjective reaction, discrepant reaction, and competitive reaction.

Subjective reaction reflects each individual's personal, unique point of view or reaction. Employees must be satisfied with the psychological as well as environmental factors relevant to job performance (Hoppock, 1935). Vroom (1964) argued that job satisfaction and work attitude often interact to indicate employees' current feelings about their work and reflect their personal affective orientation. Employees with positive attitudes toward their jobs will be satisfied with their work; employees with negative job attitudes will not be satisfied with their work (Vroom, 1964).

Campbell (1970) also agreed that job satisfaction reflects employees' positive or negative attitude or feelings toward their jobs or towards some specific facet of their jobs. Hence, job satisfaction actually is the manifestation of one's psychological state. Price (Ho, 1981) perceived job satisfaction as employees' feelings or affective reaction to the role played in the work group. Positive reaction, he believed, is an indication of job satisfaction. 
Hackman and Oldham (1980) conceived of satisfaction as general satisfaction and context satisfaction. General satisfaction is experienced when the employee feels entirely satisfied and happy with the job; whereas, context satisfaction occurs where the employee feels satisfied with specific job features, such as, job security, pay, co-workers relationships, supervision, and the opportunities for growth and personal development.

The discrepant affective reaction perspective finds support in discrepancy theory or equity theory. Porter (1961) claimed that job satisfaction is one's reaction to the difference between what one's result should be and what result one actually attains. If one's perception about what should be attained is greater than what is actually attained, one will feel less satisfied. Locke (1977, in Wexley \& Yukl, 1978) advocated that job satisfaction and dissatisfaction depend on the discrepancy between what was attained and what was expected. If there is no difference, one experiences job satisfaction.

Smith, Kendall, and Hulin (1969) considered job satisfaction the function of five types of feelings the employee has towards a job or facet of the job; that is, feelings towards the job itself, supervisor's behavior, salary, promotion, and interrelationships. When feelings about the actual rewards are equal to or not much different from expected reward, higher job satisfaction results. On the contrary, if the difference is much more than what was expected, lower job satisfaction results (McCormick \& Tiffin, 1974). Coffey, Athos, and Raynalds (1975) also viewed job satisfaction as the difference between one's expected and obtained reward. 
Competitive affective reaction goes beyond discrepant affective reaction as

follows. In addition to being determined by the difference between one's expected and actual reward, job satisfaction is also influenced by comparison to others. According to Adams (1979), "Everyone often consciously or non-consciously compares the rate of his input and what he earned with the rate of others' input and the output. If both rates are the same, then it is fair; otherwise, it is unfair" (McCormick \& Tiffin, 1974, p. 399). Hulin and Blood (1960) mentioned a related concept. They argued that the more one's job fits the standard requirement of an organization, the higher the job satisfaction. On the contrary, the less fit between job and standard requirement, the lower the job satisfaction.

\section{The Development of Job Satisfaction Studies}

Initially, the study of job satisfaction by industrial psychologists focused on the job and employees. Muneserberg's (1913) Psychology and Industrial Efficiency was the first analysis of job satisfaction. The emphasis was on personnel selection, settlement techniques, and improving working conditions. "Scientific management", advocated by F. W. Taylor, is the representative perspective on production efficiency. Taylor proposed that there was no difference between man and machine in the production process. Rather, man and machine are simply components of production tools. Frederick Taylor, Frank Gilbreth, Lillian Gilbreth, and other proponents of scientific management promoted the elevation of administrative efficiency and production ability as the primary goal of management (Baird, Post, \& Mahon, 1990). These supporters of scientific management 
proposed that: (1) In the industrial production process, money, material, men, and machines (the four M's) are the major elements for obtaining economic benefits. (2) Men and machine are the same. They have to be organized, managed, and controlled. (3) Money or economic rewards are the major motivators; thus, economic rewards must be manipulated and controlled so as to induce workers to work hard. (4) Punishment, penalty, and control must be used to manage workers' passivity and laziness. (5) Emotions must not be portrayed (Landy \& Trumbo, 1976, p. 77).

Scientific management highlighted work efficiency and ignored workers' mental proclivities. Managers promoted the production function as their only goal. To motivate workers to embrace work efficiency, managers over-stressed material gains and stimulated employees with economic rewards, thereby enhancing the willingness to work hard for monetary compensation. As a result of this trend, "industrial psychology" was referred to as "economic psychology" (Landy \& Trumbo, 1976). Material upgrades and salary raises became noticeable in organizations; it appeared that these trends related to job satisfaction. However, job satisfaction still remained a problem; employee satisfaction did not appear commensurate with the efforts exerted by management.

Thirty years later, industrial development got more and more progressive, production skills became more complicated, employees became more vahuable to the organization, so that the traditional scientific management perspective revealed shortcomings and lost its influence. Thus, the study of the employees' attitude and the relationship of attitudes and behavior became the research focus (Porter \& Lawler, 1968). 
Mayo and Roethlisberger of the Hawthome studies, indicated that employees' affective facets influence work behavior. Among the influential factors, social and mental processes are the most crucial determinants of job satisfaction and productivity (Lin, 1976). The Hawthorne studies, conducted between 1927 and 1932, showed that employers could improve work efficiency by improving the physical environment and by attending to the relationship between employees' work attitudes and work behavior. Good social relationship enhances work efficiency by motivating group members towards a strong desire to work and by letting group members know the value and significance of their individual and collective efforts. As a result of the Hawthorne studies, scholars and managers began to pay more attention to encouraging and satisfying organization members, thereby initiating studies of job satisfaction (Hoy \& Miskel, 1982).

Hoppock (1935) first conceptualized and systematically researched "job satisfaction." In Job Satisfaction (1935), Hoppock analyzed a survey of job satisfaction with data from 309 employees. He found that people working at different job levels experienced different levels of job satisfaction. He found that the higher the job position, the higher the level of job satisfaction (Landy et al., 1976; Hoy et al, 1978). Hoppock's study emphasized that external factors, such as job position, affect job satisfaction.

Coch and French (1948) pointed out the importance of personal attitudes and feelings towards one's job (Porter et al., 1968). Herzberg's (1959) "Two Factor Theory," uprooted conventional thinking about job satisfaction and influenced subsequent job satisfaction studies (Kassem \& John, 1973). Herzberg found that some special features, 
for example, accomplishment, can be called "satisfiers", because they relate closely to job satisfaction, while other features, for example, salary can be called "dissatisfiers", because they closely relate to job dissatisfaction. Such factors - satisfiers and dissatisfiers - form the foundation of the two-factor theory.

Vroom (1964) introduced the expectancy theory of job satisfaction, proposing that job satisfaction relates to personal expectation. Job satisfaction is a strategy for approaching a goal or personal satisfaction. Expectancy theory holds that motivation derives from what people expect to happen as a result of their efforts; feelings of satisfaction or dissatisfaction depend on the value the individual places on the outcome received, and performance influences future behavior by altering the effort-to-performance and performance-to-outcome expectations (Baird, Post, \& Mahon, 1990).

Adams (1965) elaborated on Vroom's theory, and proposed that job satisfaction is a function of perceived fairness and equity. Equity theory states that motivation derives from the equity people perceive to exist between their circumstances and comparable situations. If workers feel under-rewarded or over-rewarded for their performance, they will be dissatisfied and will be motivated to restore equity. Perceived inequity results when workers feel that the rewards they receive for their efforts are unequal to the rewards of other persons who exert similar efforts. Workers compare input (e.g., education, intelligence, training, seniority, effort, experience) and outcome (e.g., pay, promotions, raises, praise, esteem of co-workers, feelings of accomplishment). Employees 
who feel their ratio of inputs to outcomes is less (or more) than that of others will be dissatisfied and will try to restore equity (Baird, Post, \& Mahon, 1990).

Although it began in the area of business and industry, job satisfaction theory is widely applied. In addition to applications in business and industry, job satisfaction theories have been applied to education, starting with Hoppock's (1935) survey of 500 teachers. He found that teachers with high job satisfaction not only had better social relationships with their superiors and colleagues; they also had much less personal and psychological problems.

More recent research on teacher job satisfaction indicates that, generally, college teachers are satisfied with their work but dissatisfied with working conditions (Konicek, 1992). Additionally, internal and external factors relate significantly to satisfaction and dissatisfaction (Neal, 1990). Recent findings also show that dissatisfaction tends to be school and system centered, and relates more to school structure or administration. Satisfaction, on the other hand, tends to be more human and affective in nature (Dinham, 1994).

More specifically, studies have found that teachers' greatest sources of satisfaction are student achievement, changing student behavior and attitudes, recognition from others, self growth, mastery of subject content and teaching skills, and good relations with students, parents, and other teachers. Sources of dissatisfaction include relationships with superiors, large class sizes, lack of resources, lack of respect from students and from society (Dinham, 1994). Zelazek (1994) found that teachers are generally dissatisfied 
with the level of support from parents and the community, with salaries or fringe benefits of teaching, and with opportunities for advancement. Sorcinelli and Billings (1992) found that work stress increased and job satisfaction decreased over time. Sorcinelli and Billings also found that budgetary constraints and the lack of resources were dissatisfiers, because they were seen as detrimental to career advancement. An important implication of these recent findings is that intrinsic and extrinsic job characteristics relate significantly to satisfaction, and therefore, leaders should increase their awareness of these job characteristics and of faculty needs. They should promote a climate where faculty can exert more control over the design and operation of their work environment.

\section{The Related Theory of Teacher Job Satisfaction}

Most research on job satisfaction is based on theories of motivation (Virtue, 1992). The following three related models will be discussed: Maslow's need-hierarchy theory, Herzberg's two-factor theory, and Vroom's expectancy theory. These models are of particular relevance to guiding professional practice that seeks to build teacher motivation and commitment (Chu, 1993).

\section{Maslow's Hierarchy of Needs Theory}

Maslow, in 1962, conceptualized a hierarchy of needs arranged in the following order of priority (Good \& Brophy, 1990). 
1. Physiological needs (sleep, thirst)

2. Safety needs (freedom from danger, anxiety, or psychological threat)

3. Love needs (acceptance from parents, teachers, peers)

4. Esteem needs (mastery experiences, confidence in one's ability)

5. Needs for self-actualization (creative self-expression, attempt to satisfy one's curiosity).

When the lowest order needs are satisfied, higher-order needs appears; then the individual attempts to satisfy that higher order need, which has greater potency (Owens, 1991).

Abdel-Halim (1980) used Maslow's model and postulated that job satisfaction is based upon meeting the various levels of needs. Satisfied needs do not motivate, but unsatisfied needs do. Stated in another manner, once basic extrinsic needs are satisfied, intrinsic needs assume greater importance (Strauss et al., 1976).

Many organizations fail to recognize this, and follow, instead, McGregor's Theory $\mathrm{X}$, assuming workers dislike work and wish to avoid responsibility. Often, work is structured in such a fashion that individuals are condemned to isolation, dependence, and the minimal use of their abilities (Strauss et al, 1976).

Theory $\mathrm{Y}$ organizations operate on the assumption that people like to work, want to achieve, are proud of their talents and want to see those talents utilized. To adhere to this theory, management should create conditions where workers have an opportunity to express their ideas and make the most of their talents (Brodinsky et al, 1983). On the 
other hand, Ouchi's (1982) Theory $Z$ recognizes a participative management style which is closely related to morale, motivation, and effectiveness - three factors critical to needs satisfaction.

\section{Herzberg's Two-Factor (Motivation-Hygiene) Theory}

The motivation-hygiene theory, developed by Herzberg (1966) and discussed by Miner and Miner (1973), identifies two classes of job factors. One class includes extrinsic job factors that cause dissatisfaction with a job, for example, salary, fringe benefits, type of supervision, working conditions, climate of work group, and attitudes and policies of the administration. The other class includes intrinsic job factors, which are related to job satisfaction, for example, achievement, recognition, the challenge of the work itself, responsibility, advancement and promotion, and personal or professional growth.

The motivation-hygiene theory is as applicable to teachers as it is to professionals in business and industry, because the theory deals with both job content (motivators) and job context (hygiene or maintenance) (DuBrin, 1984). Herzberg (1966) argued that factors of job satisfaction relate to what teachers do, while factors of dissatisfaction relate to the situation in which teachers work. Sergiovanni (1969) stated that the factors which contributed to teacher work satisfaction were achievement, recognition, and responsibility; teacher dissatisfaction was related to school policy and administration, interpersonal relations, nature of supervision, and personal life. Greenberg (1980) suggested that the 
level of extrinsic or intrinsic motivation present in the work is what primarily contributes to teachers' job satisfaction.

Savage (1967), using interviews to obtain data from Georgia teachers, and Wickstrom (1971), discussing a study of teachers, found that Herzberg's theory was generally supported. Sergiovanni (1969), after replicating Herzberg's work among teachers in the late 1960 s, reported that the theory appears to be supported. He made the point that advancement, frequently an important motivator in studies conducted in private sector corporations, was missing in the study of teachers (Owens, 1991).

College presidents need to be concerned with both extrinsic and intrinsic rewards. Herzberg's Two-Factor Theory (1966) can provide them with a cognitive map for ensuring that administrative, organizational, and teaching practices provide for both extrinsic and intrinsic rewards.

\section{Vroom's Expectancy Theory of Motivation}

Although there are various models of expectancy theory, the best known and most widely used is that developed by Vroom, whose work focused especially on the motivation of employees in organizations (Owens, 1991). The expectancy theory is based on the concept that the worker may rationally expect that desirable rewards are likely to be the predictable outcome of certain behavior. There are two basic assumptions in this theory. First, individuals make decisions about their own behavior in organizations, using their abilities to think, reason, and anticipate future events. Motivation is a conscious 
process. Individuals subjectively assess expected outcomes, personal gains or consequences of their behavior, and then decide how to behave. The second assumption is that the interaction of individuals and the environment determines behavior. Personal values and attitudes interact with environmental factors such as role expectations and organizational climate to mold behavior.

Vroom's model of expectancy theory depends on three concepts: valence, instrumentality, and expectancy (Burk, 1991). Owens (1991) explains each as follows: Valence refers to the degree of preference one has for a potential outcome. Valence can be either positive (desired) or negative (not desired). In short, valence defines what an individual wants from a job. For the concept of valence, outcome represents the consequence of one's behavior; first-level outcome is the direct, or immediate, consequence of one's behavior; second-level outcome refers to the personal impact that the first-level outcome has on the individual. Expectancy is the belief that a behavior will result in predictable, first-level outcome. Instrumentality refers to the strength of the correlation between the first-level outcome (e.g., improved test scores) and the second-level outcome (e.g., being granted tenure).

The basic notions of this theory are: (1) one experiences motivations in varying intensities, depending upon the complex interplay of valence-expectancy-instrumentality, (2) one usually will choose to behave in response to the motivational forces that are strongest, and (3) one is motivated by expected events and likely outcomes of altemative ways of dealing with them (Owens, 1991). 
Miskel, DeFrain, and Wilcox (1980) concluded that the anticipation of successful performance by teachers was a necessary requirement for job satisfaction. In order to be motivated, teachers need to believe that they will be successful in doing what is necessary to obtain desired rewards. Therefore, administrators should provide conditions that enhance teachers' anticipation of desirable and significant rewards (Chu, 1993).

\section{Related Instruments and Their Results}

\section{Leadership Orientations}

Bensimon $(1988,1989)$ used the Leadership Orientations Questionnaire to study college presidents and found that multiframe presidents were viewed as more effective than single-frame presidents. Bensimon also found that presidents who relied solely on the structural frame were particularly likely to be seen as ineffective leaders. He also found that presidents thought they relied on more frames than their colleagues saw them use.

Bolman (1989) used the Leadership Orientations Questionnaire to study a group of European managers from a multinational corporation and found that these managers rated themsetves higher on the human resource and symbolic frames than did their colleagues, but lower on the structural and political frames.

\section{Job Descriptive Index (JDI)}

Collmer (1989) used the Job Descriptive Index to survey 200 teachers in thirty-four school districts. The study focused on the extent to which teacher-perceived 
attitudes of principals directly influenced how the teacher rated job satisfaction. Collmer's research suggested that the satisfaction, motivation, and human relations aspects of teaching must be considered by school administrators. Principals are urged to develop meaningful two-way communication with their teachers. Research (Collmer, 1989) also indicated that job dissatisfaction produced low morale, absenteeism, and inept or uncaring teachers, and that effective schools had strong leaders and teachers who were caring and dedicated.

Ozumba (1987) used The Job Descriptive Index to survey 400 secondary school teachers in an effort to determine the relationship between administrative leadership style and teacher job satisfaction. The author found: 1) significant differences in the teachers' perception of their principals' leadership styles: autocratic, democratic, laissez-faire, etc; 2) a significant relationship between perceived leadership style and several aspects of job satisfaction including work, supervision, and co-workers; 3 ) no relationship between satisfaction with pay and perceived leadership style.

Wilcox (1992) used the Revised Job Descriptive Index to survey 1,091 high school teachers for a study of the relationship among teachers' perception of the high school principals' leadership styles, job satisfaction, and teacher morale. The findings indicated that leadership styles usually predict degree of job satisfaction and teacher morale. Furthermore, team or participatory leadership style accounted for a significant amount of unique variance in predicting job satisfaction. 
The Job Descriptive Index, or JDI, covers five principal facets: work, pay, promotions, supervision, and coworkers (Smith, Kendall, \& Hulin, 1969, 1985). This instrument has proved reliable and valid, and is very widely used (Cranny, Smith, \& Stone, 1992).

\section{Summary}

Research supports the precept that, in general, a leader's effectiveness is based upon leadership style and an appropriate match of that style to the situation in which the leader functions. College presidents as leaders "must create something new out of something old: out of an old vision, they must develop and communicate a new vision and get others not only to see this vision but also to commit themselves to it" (Tichy \& Ulrich, 1984, p. 59). Effective presidents create conditions to help teachers realize their values, and provide professional autonomy, daily recognition, and encourage involvement in decision making (Chu, 1993, p. 78).

Brodinsky (1984) conchuded that strengthening job satisfaction in the school environment resulted in improved productivity. Teachers satisfied with their job tend to be more committed to the job, more creative, prouder of the job, less frequently absent, and more caring for students (Miller \& Spark, 1984; Smith, 1984). Presidents' motivation of teachers should be grounded in shared values, empowerment, and cooperation (Chu, 1993). When presidents and teachers support each other, a positive emotional climate is created that pervades the atmosphere of the entire school (Collmer, 1989). 
The trend toward more comprehensive, multiframe approaches is rapidly gathering momentum (Bolman \& Deal, 1991). Bolman and Deal's $(1984,1991)$ four frames (structure, human resource, political, and symbolic) help researchers and practitioners understand organizations and leadership. How well the frames work depends on both the situation and the skills of the person who applies the frames approach. Each of the frames can be applied well or poorly, depending on the skills and artistry of the individual. Most leaders or managers feel more comfortable and confident with some of the frames than with others, but many are also surprised to learn that they can discover new possibilities and expand their own leadership effectiveness by practicing and applying frames outside their usual range of behavior.

This study attempts to enhance the understanding of leadership effectiveness by investigating the relationship between leadership style and job satisfaction. Leadership research indicates that personal attributes, behavioral attributes, and situational factors affect leadership and leadership affects employee satisfaction (Stogdill, 1985). Research has identified several environmental, individual, and task-related factors that influence employee satisfaction and performance. Bolman and Deal (1991) proposed a four-frame leadership theory that collectively takes into account most personal, behavioral, and situational factors. The four frame model is used to investigate presidents of Taiwan junior colleges. This model collectively provides useful insights into facets of leadership which cannot be appreciably discerned by looking at only isolated components of the 
model. The four frame model will be used to determine the extent to which presidents' behavior influences aspects of the job itself, supervision, pay, co-workers, and promotion. 


\title{
CHAPTER THREE
}

\section{RESEARCH METHODOLOGY}

\author{
Introduction
}

The purpose of this dissertation is to investigate the relationship between the leadership styles of Taiwanese junior college presidents and teacher job satisfaction. In this chapter, the major variables examined are identified and defined; the procedures, instrumentation, sample selection, data collection, and analytical techniques are described.

\section{Variables}

The dependent variable under consideration is teacher job satisfaction. The independent variable is presidents' leadership style. Teacher job satisfaction is operationalized as the feelings workers have about their jobs or job experiences. Presidents' leadership style is operationalized as structural, human resource, political, symbolic, or any combination of the four-frame perspective of Bolman and Deal (1991).

\section{Research Design}

The research question, and review of the related literature indicate certain institutional and personal factors that affect presidents' leadership style and teacher job satisfaction. Institutional factors which affect president's leadership style include school status and size. Personal factors include: president's age and job tenure. Institutional factors which affect job satisfaction are school status and size. Personal factors include: 
teacher's sex, age, length of service, educational background, position or academic rank, and administrative task.

\section{Leadership Style}

There are four organizational frames in which a college president's leadership style can be classified: structural, human resource, political, and symbolic (Bolman \& Deal, 1991). This study determined the dominant frame of junior college presidents in Taiwan. The responses to questionnaire items provided information about presidents' and teachers' perceptions of presidents' leadership style. Participants were asked to indicate the extent to which certain statements are true (See 'President's Leadership Orientations Questionnaire", Appendix C and part one of 'President's Leadership Orientations and Teachers Job Satisfaction Questionnaire", Appendix D). The items represent behaviors pertinent to each of the four frames. The use of one dominant frame or multiple frames will be determined by the ratings of the participants. The responses of teachers of each college will be averaged. The assessment of each president's frame will be based on the mean of the responses of the teachers in each college.

\section{Determining Frames}

The items in the questionnaires for teachers and presidents were ordered in fours so that each of the four frames (structural, human resource, political, symbolic) was represented in turn. For example, 32 items in the teachers' questionnaire represented each 
frames as follows: (1) structural frame: items $50,54,58,62,66,70,74,78 ;(2)$ human resource frame: $51,55,59,63,67,71,75,79 ; 3)$ political frame: $52,56,60,64,68,72$, 76,$80 ;(4)$ symbolic frame: $53,57,61,65,69,73,77,81$.

The mean was calculated for each frame: M1 (structural), M2 (human resource), M3 (political), M4 (symbolic). Responses from teachers and presidents were calculated, and means obtained for each respondent. For example, for each frame, "teacher A" received M1-a, M2-a, M3-a, M4-a. If a teacher's mean was larger than the calculated frame mean, that teacher's president uses that frame. Thus, if M1-a $>$ Ml, teacher A's president uses the structural frame. If a teacher's mean was smaller than or equal to a calculated frame mean, that teacher's president does not use the frame. Thus, if M2-a $\leq$ M2, teacher A did not perceive his or her president as using the human resource frame. As stated earlier, the same procedure was used to determine how presidents view their own use of the four frames.

$\underline{\text { Job satisfaction }}$

Teacher job satisfaction was measured by the Job Descriptive Index developed by Smith, Kendall, and Hulin (1969). The scale considers overall job satisfaction and important facets of job satisfaction. The modified version of the index used in this study is called Junior College Teachers Job Satisfaction Questionnaire. The five dimensions of job satisfaction covered are the teaching job itself, school environment, administration /supervision, job remuneration, and promotion. The degree of teacher job satisfaction was 
determined by the ratings of job satisfaction on the Junior College Teacher Job Satisfaction Questionnaire.

Figure 1, the Theoretical Framework of the Study, summarizes the relationships among the institutional and personal factors, president's leadership style, and teacher job satisfaction. The research questions (p. 8) posed the relationships among the variables. Arrow Q1 represents the relationship between job satisfaction and teachers' perception of presidents' leadership frames (Does degree of job satisfaction relate to teachers' perception of leadership frame?). Q2 portrays the degree of agreement or congruence between presidents' self-perception of leadership frames used and teachers' perception of presidents' frame ( To what degree do teachers' perception of presidents' leadership frame agree with presidents' self-perception of leadership frame used?). QS1 represents the first subsidiary question. It portrays the relationship between leadership frames and personal and institutional factors which may influence leadership frames ( Does the leadership frame of presidents differ significantly with such presidents' demographics as school status, school size, presidents' age and presidents' job tenure?). QS2 represents the second subsidiary research question. It portrays the relationship between teacher job satisfaction and certain institutional and personal factors that may influence teachers' perception of job satisfaction (Do teachers' perceptions of job satisfaction vary with such teacher demographics as gender, age job tenure, educational background, academic position, school status, and school size?). 


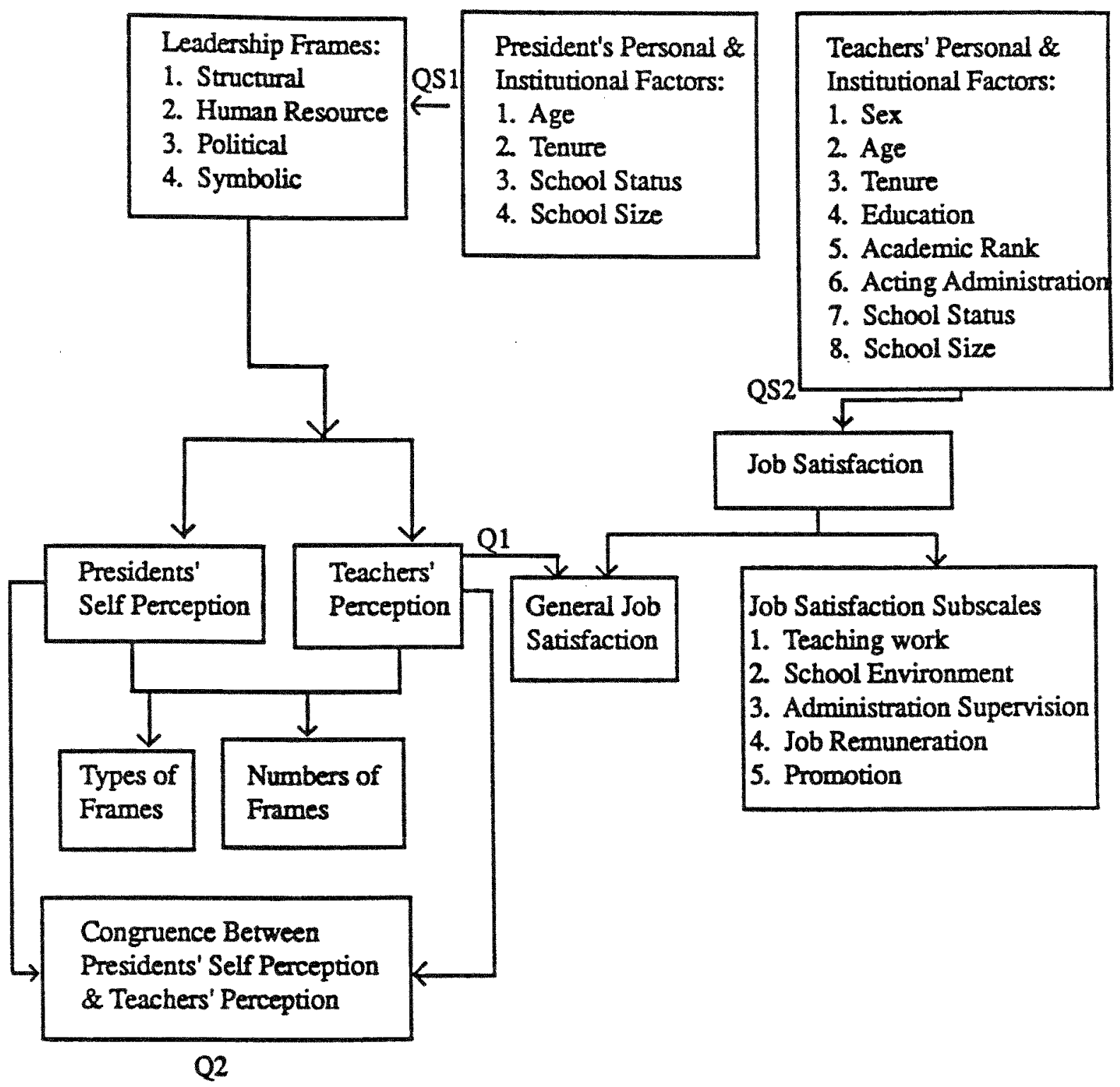

Figure 1. Theoretical Framework of the Study 


\section{Teacher Job Satisfaction Questionnaire}

The 41-item survey instrument is based on Smith, Kendall, and Hulin's (1969) 72item Job Description Index (JDI). The data collected through administration of questionnaire served to determine teachers' perception about their job (teaching) in general and about five specific aspects of teaching: teaching itself, environment, administrative/supervision, promotion, and job remuneration.

\section{Developing the Teacher Job Satisfaction Questionnaire}

The Job Description Index (JDI) is applicable to all job situations. This investigation focused on teaching; therefore, original terminology was altered to reflect the teaching situation. For example, the designations of four of the five JDI subscales - work, coworkers, supervision, pay, and promotion - were changed respectively as follows: teaching itself, environment ( inchudes other critical components of the workplace, students, for instance), administrative/supervision (reflects situations where teachers may have some administrative function that may not be supervisory in nature), job remuneration (reflects benefits or compensation in addition to salaries or pay). "Promotion" was not changed.

All 72 items of the original were not used; neither were the exact wording of the selected items used. Other items and wordings more appropriate for teachers were obtained from the literature or suggested by educators. Fifty-two items were generated 
and submitted for review to scholars, experts, educational administrators, and experienced teachers. The purposes of the review were: to modify the contents and language of the questionnaire, and to determine whether the items were consistent with the concept of job satisfaction, the purpose of the study and the research questions. Several items were deleted or revised. The final questionnaire consisted of 41 items, with five categories of Likert-type responses, from 1 ("very dissatisfied") to 5 ("very satisfied"). The JDI has three response categories (Yes, No, ? (? suggests uncertainty)). The Modified JDI developed for this study has a five-point Likert scale which gives respondents more flexibility in indicating their perceptions.

The items on the final questionnaire were ordered in five's, so that one item for each subscale was represented in tum, as follows: (1) teaching itself: items 9, 14, 19, 24, $29,34,39,44 ;(2)$ environment: $10,15,20,25,30,35,40,45 ;(3)$ administrative/supervision: $11,16,21,26,31,36,41,46 ;(4)$ job remuneration: 12,17 , $22,27,32,37,42,47 ;(5)$ promotion: $13,18,23,28,33,38,43,48$. The overall mean was calculated for each subscale. The mean of responses of each respondent was also calculated. Rather than use JDI's items for job satisfaction in general (respondents' perception of their overall job satisfaction), this investigation used the composite mean for the five subscales. 


\section{Pilot testing}

The Teacher Job Satisfaction Questionnaire was pilot tested at Chien-Kuo Junior College of Technology and Commerce. The "pilot" subjects were sent a statement about the purpose of the survey and were asked for reaction to, and suggestions regarding, readability, understanding, ease of completion, and clarity of each item. The data collected were used to estimate the reliability of the instrument.

\section{Reliability and Validity}

Following the collection of the data, the reliability of the instrument was assessed, using Gay's (1994) criterion of .70 as the acceptable reliability coefficient. The degree of reliability was determined by Cronbach's alpha. Based on the statistical analysis of data from 40 teachers, the procedure resulted in the following alpha coefficients: teaching itself, .83 ; school environment, 68 ; administrative supervision, .92 ; job remuneration, .73 ;

promotion,. 86 . Total or overall job satisfaction is .95 . Because the reliability coefficient of all but one dimension as well as the combined dimensions exceed the .70 criterion, the questionnaire is considered reliable.

The construct validity of the teacher job satisfaction questionnaire was determined by experts (i.e., college level educators) in the U.S. and Taiwan. These persons included deans of industrial education programs and chairpersons of departments of psychology. They were asked to examine the contents of the questionnaire to ensure that the contents, research purpose, and items matched. The educators were asked whether each item of the 
measure represented the construct "job satisfaction" and whether the language was clear. If the response was negative, the educator was asked to suggest items and language that improved the item. These experts or educators approved items that represented the construct "job satisfaction" and the five aspects considered; likewise, they suggested items for replacement, deletion, or revision for those items that did not sufficiently represent the constructs. Items that received negative responses were replaced by the suggested items and resubmitted to the experts for revaluation. The Teacher Job Description Index was considered construct valid when it received an affirmative from all educators.

\section{Leadership Orientations Questionnaire}

The Leadership Orientation Questionnaire was developed by Bolman and Deal (1991) to measure the four organizational frames along the eight (parenthesized) dimensions: 1) human resource frame (supportive, participative), 2) structural frame (analytic, organized), 3) political frame (powerful, adroit), 4) symbolic frame (inspirational, charismatic). The dimensions are defined as follows (Bolman \& Deal, 1991).

1. Human Resource Dimensions

(a) Supportive - concemed about the feelings of others; supportive and responsive.

(b) Participative - fosters participation and involvement; listens and is open to new ideas. 
2. Structural Dimensions

(a) Analytic - thinks clearly and logically; approaches problems with facts and attends to detail.

(b) Organized - develops clear goals and policies; hold people accountable for results.

3. Political Dimensions

(a) Powerful - persuasive, high level of ability to mobilize people and resources; effective at building alliances and support.

(b) Adroit - politically sensitive and skillful; a skillful negotiator in face of conflict and opposition.

4. Symbolic Dimensions

(a) Inspirational - inspires others to loyalty and enthusiasm; communicates a strong sense of vision.

(b) Charismatic - imaginative, emphasizes culture and values; is highly charismatic.

The Leadership Orientation Questionnaire has two parallel forms. Presidents rate themselves on one form; subordinates (e.g., teachers) rate presidents on the other. The forms employ two different approaches to measuring leadership frames. The first section uses a 5-point rating scale, organized around the eight dimensions of leadership. The second section of the instrument contains a series of forced-choice items. Each item gives 
four options, allowing respondents to rank responses from 4 (most like this individual) to 1 (least like this individual).

\section{Reliability and Validity}

The items for each scale were selected from a larger pool generated by Bolman and Deal and their colleagues. The instrument was pilot tested on populations of both students and managers to assess the internal reliability of each scale. The instrument is now in its third iteration, and internal reliability is very high; Cronbach's alpha for each frame measure ranges from .91 to .93 (Bolman \& Deal, 1991).

According to Kerlinger (1973), a construct can be validated by using factor analysis to verify the initial conception of the construct. Bolman and Deal (1991) used factor analysis to determine the extent to which the items in their instrument measured each the four frames. They reported that their analyses consistently produced factors associated with the frames and that the four largest factors corresponded to the four frames. Their results indicated that the measures are content as well as construct valid.

\section{Sample Selection}

The target population for this study included presidents and full-time teachers of all Taiwanese public and private five, three, and two-year junior colleges.

According to Taiwan's Department of Technological and Ministry of Vocational Education, there were 71 junior colleges ( 12 public, 59 private) during the 
1994 academic year. The process of random sampling was used to select 24 junior colleges ( 4 public, 20 private) in the first stage of sample selection. All 24 presidents were included in the study. In the second stage, $10 \%$ of the full time teachers from each of the 24 colleges were selected through the process of convenient sampling. The president of each college was asked to identify and select the teachers. Subsequently, the total sample size was 24 presidents and 403 teachers.

\section{Data Collection}

Two instruments were used to gather data for this study. The Leadership Orientations Questionnaire allowed presidents to rate themselves and also allowed teachers to rate the presidents. The Teacher Job Satisfaction Questionnaire allowed teachers to indicate their perceived level of satisfaction with their jobs. The teachers' instrument was titled "President's Leadership Orientations and Teachers Job Satisfaction Questionnaire", since it contained both the leadership and job satisfaction sections.

Both questionnaires were mailed to the presidents of the 24 junior colleges on September 25, 1995. Each president was requested to complete one Presidents' Leadership Orientations Questionnaire and to distribute the Teachers' Questionnaire to the faculty members, who were conveniently selected by the president. The presidents were also requested to collect and mail the completed questionnaires to two professors who assisted the researcher in facilitating this study in Taiwan. The college presidents provided them with information regarding the faculty members selected for the study. The 
professors made follow-up telephone calls to presidents and teachers who did not return their questionnaires within two weeks. By October 20, 1995, the researcher had received $20(83.3 \%)$ presidents' questionnaires and $296(73.4 \%)$ teachers' questionnaires. All 20 $(83.3 \%)$ of the presidents' questionnaires were usable; two hundred eighty-two (282) or $70.0 \%$ of the teachers' questionnaires were usable. Discarded questionnaires consisted of those that were incomplete and those which did not meet the criteria for participation. To facilitate statistical analyses, the usable questionnaires were coded and a computer file established through the use of the SPSS software package.

\section{Analysis of the Data}

Of the returned questionnaires, only the fully completed ones were used for analyses. The data were analyzed by t-test, ANOVA, Chi-Square, and Scheffe's test for making pairwise comparisons. All variables were subjected to a descriptive analysis that yielded frequencies, percentages, means, standard deviations, and alpha coefficients. In keeping with the convention of empirical research, the results of this study were tested at the 0.05 level of significance.

The t-test for two group comparisons was used to determine significant differences in: 1) leadership behavior and presidents' age, tenure, and school status, and 2) teachers' gender, administrative task, school status, and job satisfaction.

Analysis of variance (ANOVA) was used to: 1 ) determine differences in leadership style by school size, 2) determine differences in teacher job satisfaction with age, tenure, 
education, academic rank, and school size, and 3) determine differences in leadership style, overall job satisfaction, and specific dimensions of job satisfaction. In all of these tests, Scheffe's method was used to perform all possible pairwise comparisons between the means, to find out which means differ significantly. Chi-Square analysis determined the degree of agreement between teachers' perception of presidents' frame and presidents' self perception. All tests were conducted at the 0.05 level of significance. 


\section{CHAPTER FOUR}

\section{RESULTS OF THE STUDY}

The purpose of this dissertation was to investigate the relationship between the leadership styles of Taiwanese junior college presidents and teacher job satisfaction. This chapter presents the results of the study.

Questionnaires were distributed to 24 presidents and 403 teachers. The return rate was $83.3 \%(20)$ for presidents and $70.0 \%(282)$ for teachers. These questionnaires were fully completed, and therefore usable. Data were analyzed by t-tests, ANOVA, Chisquare, and Scheffe's test for comparing contrasts.

Descriptive statistics (means, standard deviations, frequencies, and percentages) are presented in appropriate tables. All analyses were computed with the use of the SPSS program. The significance of the results was tested at the .05 level.

Teachers' demographic data include school status (public or private) and size, gender, age, length of service, educational level, academic rank, and administrative tasks. Presidents' demographics include school status and size, age, and length of service. Tables 4-1 and 4-2 provide percentages and frequencies for teachers and presidents, respectively. The results of the study are discussed in Chapter Five (pages 80 through 92).

Addressing the Research Questions

The following procedures were used to answer each of the research questions.

Research Question One: What is the relationship between teachers' perception of their 
Table 4-1

Demographic Data of Respondents

Respondents (Teacher) Frequency Percentage

1. School Status

Public

Private

51

231

2. School Size

under 3000

$3001-5000$

over 5001

3. Gender

Male

Female

4. Age

under or 29 years old

30 - 39 years old

40 - 49 years old

$50-59$ years old

60 years old or above

5. Length of Service
1 - 3 years
$4-10$ years
$11-15$ years
16 - 20 years
21 years or more

6. Educational Level

Doctor

Master

Bachelor

Junior College

Other

7. Position Rank

Professor

Associate Professor

Assistant Professor

Instructor

Assistant

8. Administrative Task

Yes

No
51

109

122

190

92

34

175

53

15

5

86

131

29

16

20

24

210

38

7

3

9

38

2

216

17

117

165
$18.1 \%$

$81.9 \%$

$18.1 \%$

$38.7 \%$

$42.2 \%$

$67.4 \%$

$32.6 \%$

$12.1 \%$ $62.0 \%$ $18.8 \%$

$5.3 \%$

$1.8 \%$

$30.5 \%$ $46.5 \%$

$10.2 \%$

$5.7 \%$

$7.1 \%$

$8.5 \%$

$74.4 \%$

$13.5 \%$

$2.5 \%$

$1.1 \%$

$3.2 \%$

$13.5 \%$

$.7 \%$

$76.6 \%$

$6.0 \%$

$41.5 \%$

$58.5 \%$ 
Table 4-2

Demographic Data of Respondents

Respondents (President) Frequency Percentage

1. School Status

Public

Private

2. School Size

under 3000

$3001-5000$

over 5001

3. Age

under 44 years old

45 yrs old or above

4. Time on the Job

under or 6 years

7 years or more
3

17

$15 \%$

$85 \%$

presidents' leadership frame and teachers' general job satisfaction? This study operationalized teachers' perception of leadership frames as the number and type of frames used by their presidents. Thus, two sub-questions here were how many frames each president used and which frame or combination of frames were used. Tables 4-3 and 4-4 show frequencies and percentages of teachers' response to each of the sub-questions, respectively.

The results from the question on the number of frames (Table 4-3) indicate that two-frame style received the highest frequency $(94 / 33.3 \%)$ and 31 respondents reported no frame, suggesting that perhaps, for those individuals, the presidents' leadership frame was unclear or imprecise. Perceived use of one, three, and four frames received equal frequencies. 
Table 4-3

How Many Frames Do Presidents Use? (Teachers' Perception)

\begin{tabular}{lccc}
\hline How Many Frames? & Frequency & Percentages & Valid $\underline{\mathrm{N}}$ \\
\hline 0 Frame & 31 & $11.0 \%$ & 282 \\
One Frame & 56 & $19.9 \%$ & 282 \\
Two Frames & 94 & $33.3 \%$ & 282 \\
Three Frames & 50 & $17.7 \%$ & 282 \\
tour Frames & 51 & $18.1 \%$ & 282 \\
\hline
\end{tabular}

Regarding the second subsidiary question (which frames do presidents use?), human resource, political, and symbolic frames received almost equal frequencies; whereas, structural was lower (Table 4-4).

Table 4-4

Which Frames Do Presidents Use? (Teachers' Perception)

\begin{tabular}{lccc}
\hline Which Frames? & Frequency & Percentages & Valid $\underline{\mathbf{N}}$ \\
\hline Structural & 131 & 46.4 & 282 \\
Human Resource & 158 & 56.0 & 282 \\
Political & 155 & 55.0 & 282 \\
Symbolic & 154 & 54.6 & 282 \\
\hline
\end{tabular}

The relationship between teacher job satisfaction and the type and number of frames was of interest to this researcher. As indicated in Table 4-5, the results show no significant relationship between teachers' perception of the type of frame (structural, human resource, political, symbolic) and general job satisfaction. 
Table 4-5

Mean, Standard Deviation of General Job Satisfaction on Frames Used

\begin{tabular}{lllll}
\hline ScaleM & M & SD & F- Value & P- Value \\
\hline Structural & 3.8715 & .4487 & .6473 & .5849 \\
Human Resource & 3.8722 & .4657 & \\
Political & 3.8083 & .5220 & \\
Symbolic & 3.8652 & .4499 & &
\end{tabular}

No significance.

The results on number of frames used, however, indicate that teachers who thought their presidents used multiple frames are more satisfied than teachers who thought their presidents used single frames. As Table 4-6 portrays, general job satisfaction increases with the number of frames used. Teachers who perceived their presidents as using none of the four frames are the least satisfied, as the mean $(M=3.1213)$ indicates; while teachers who perceived their presidents as using all four frames are the most satisfied $(M=4.1286)$.

Table 4-6

Mean, Standard Deviation of General Job Satisfaction on Number of Frames

\begin{tabular}{lllll}
\hline \multicolumn{1}{c}{ Scale } & M & SD & F value & P-Value \\
\hline 0 Frame (G1) & 3.1213 & .5411 & 50.7573 & $.0000^{* * *}$ \\
One Frame (G2) & 3.2580 & .3744 & & \\
Two Frames (G3) & 3.6595 & .3830 & \\
Three Frames (G4) & 3.9458 & .3603 & \\
Four Frames (G5) & 4.1286 & .4234 & \\
\hline$* * \mathrm{p}<.001$ & & & & \\
\hline
\end{tabular}


Table 4-7 gives the results for multiple comparisons of general job satisfaction and number of frames (from group 1, representing 0 frame, to group 5 , representing 4 frames). The results show some significant differences between groups. Group 3 (two frames) was more satisfied than groups 1 and 2; group 4 was more satisfied than groups 1,2 , and 3; group 5 was more satisfied than groups 2 and 3.

\section{Table 4-7}

Multiple Comparison of General Job Satisfaction on Number of Frames (F)

\begin{tabular}{llccccc}
\hline Mean & $\begin{array}{c}\text { How Many } \\
\text { Frames }\end{array}$ & Grp 1 & Grp 2 & Grp 3 & Grp 4 & Grp 5 \\
3.1213 & Grp 1 $=0$ & & & & & \\
3.2580 & Grp 2=1 & & & & & \\
3.6595 & Grp 3=2 & $*$ & $*$ & & & \\
3.9450 & Grp 4=3 & $*$ & $*$ & $*$ & & \\
4.1286 & Grp 5=4 & $*$ & $*$ & $*$ & & \\
$* p<.05$ & & & & & & \\
\hline
\end{tabular}

Research Question Two: What is the degree of agreement between teachers' perception of presidents' frame and the presidents' self-perception? The results of a Chi-Square test indicated that there is congruence between teacher and president perception of the type and number of leadership frame the president used. As Table 4-8 shows, there is no significant difference between presidents' and teachers' perception of which frame the president used, with Chi-Square $=.01701(\mathrm{p}>.05)$. Table 4-9 shows no significant difference between presidents' and teachers' perception of the number of frames used $($ Chi-Square $=2.46976, \mathrm{p}>.05)$. 
Table 4-8

Which Frames Do Presidents Use?

\begin{tabular}{|c|c|c|c|c|c|c|c|c|}
\hline \multirow[t]{2}{*}{$\begin{array}{l}\text { Which } \\
\text { Frames? }\end{array}$} & \multicolumn{3}{|c|}{$\begin{array}{l}\text { Teachers' Perception } \\
\qquad(\mathrm{N}=282)\end{array}$} & \multicolumn{3}{|c|}{$\begin{array}{l}\text { Presidents' Perception } \\
\qquad(\mathrm{N}=20)\end{array}$} & \multirow[t]{2}{*}{ Chi-Square } & \multirow[t]{2}{*}{ P-Value } \\
\hline & $\mathbf{M}$ & $\mathrm{N}$ & $\%$ & $M$ & $\mathrm{~N}$ & $\%$ & & \\
\hline Structural & 3.58 & 131 & $46.5 \%$ & 3.56 & 10 & $50.0 \%$ & .01701 & .99941 \\
\hline Human Resource & 3.54 & 158 & $56.0 \%$ & 3.65 & 13 & $65.0 \%$ & & \\
\hline Political & 3.47 & 155 & $54.9 \%$ & 3.39 & 11 & $55.0 \%$ & & \\
\hline Symbolic & 3.50 & 154 & $54.6 \%$ & 3.74 & 9 & $45.0 \%$ & & \\
\hline
\end{tabular}

No significance.

Table 4-9

How Many Frames Do Presidents Use?

\begin{tabular}{|c|c|c|}
\hline $\begin{array}{l}\text { How Many } \\
\text { Frames? }\end{array}$ & $\begin{array}{l}\text { Teachers' Perception } \\
(\mathrm{N}=282)\end{array}$ & $\begin{array}{l}\text { Presidents' Perception } \\
(\mathrm{N}=20)\end{array}$ \\
\hline
\end{tabular}

\begin{tabular}{lllll}
\hline $0 \quad$ Frame & $11.0 \%$ & $10.0 \%$ & 2.46976 & .65006 \\
One Frame & $19.9 \%$ & $15.0 \%$ & & \\
Two Frames & $33.3 \%$ & $35.0 \%$ & & \\
Three Frames & $17.7 \%$ & $30.0 \%$ & & \\
Four Frames & $18.1 \%$ & $10.0 \%$ & &
\end{tabular}

No significance.

Subsidiary Research Question One: Does the leadership frame of junior college presidents differ significantly when considering school status and size, and president's age and job tenure? Results of t-tests show that presidents' leadership frame does not differ with age, job tenure, or school status. Table 4-10 Shows results obtained by using the means of teacher's responses to the question of which frame (structural, human resource, 
political, symbolic). Results of a one-way ANOVA show that presidents' leadership frame does not differ with school size (Table 4-10A). In both Tables 4-10 and 4-10A, p-values are parenthesized.

Table 4-10

T-test: Type of Frames and Presidents' Age. Tenure, and School Status

\begin{tabular}{|c|c|c|c|c|c|}
\hline \multirow{2}{*}{$\mathbf{P}$. } & \multirow[t]{2}{*}{$\mathbf{N}$} & \multirow{2}{*}{$\begin{array}{c}\text { M1 (St.) P. } \\
3.1708\end{array}$} & \multirow{2}{*}{$\begin{array}{c}\text { M2 (H.R.) P. } \\
3.3885\end{array}$} & \multirow{2}{*}{$\begin{array}{c}\text { M3 (P.) P. } \\
3.0677\end{array}$} & \multirow{2}{*}{$\begin{array}{c}\text { M4 (Sy.) } \\
3.4073\end{array}$} \\
\hline & & & & & \\
\hline \multicolumn{6}{|l|}{$\overline{\text { Age }}$} \\
\hline 1. under 44 & 2 & $\begin{array}{r}3.2292 \\
(.868)\end{array}$ & $\begin{array}{l}2.9792 \\
(.187)\end{array}$ & $\begin{array}{l}2.6250 \\
\quad(.152)\end{array}$ & $\begin{array}{l}3.4167 \\
(.971)\end{array}$ \\
\hline 2. over 45 & 18 & 3.1644 & 3.4340 & 3.1169 & 3.4062 \\
\hline \multicolumn{6}{|l|}{ Time on Job } \\
\hline 1. under 6 & 5 & $\begin{array}{l}3.2823 \\
(.576)\end{array}$ & $\begin{array}{l}3.2500 \\
(.447)\end{array}$ & $\begin{array}{l}2.8458 \\
\\
(.217)\end{array}$ & $\begin{array}{r}3.2208 \\
(.202)\end{array}$ \\
\hline 2. over 7 & 15 & 3.1333 & 3.4347 & 3.1417 & 3.4694 \\
\hline \multicolumn{6}{|c|}{ School status } \\
\hline 1. public & 3 & $\begin{array}{r}3.1111 \\
(.830)\end{array}$ & $\begin{array}{r}3.3819 \\
(.979)\end{array}$ & $\begin{array}{l}2.6528 \\
(.087)\end{array}$ & $\begin{array}{r}3.3542 \\
(.796)\end{array}$ \\
\hline 2. Private & 17 & 3.1814 & 3.3897 & 3.1409 & 3.4167 \\
\hline
\end{tabular}

No significance 
Table 4-10A

ANOVA: Type of Frame and School Size

$\begin{array}{lllll}\mathrm{N} & \text { M1 (St.) } & \text { M2 (H.R.) } & \text { M3 (P.) } & \text { M4 (Sy.) } \\ & 3.1708 & 3.3885 & 3.0677 & 3.4073\end{array}$

School size

1. $<3000$

3

3.0139

3.0833

3.1250

3.3819

2. $3001-5000$

3.2743

3.2188

3.2465

3.6450

3. over $5001 \quad 11$

3.1572

3.5644

2.9545

3.2841

$\mathrm{F}=.2574$

$\mathrm{F}=2.1409$

$F=.8104$

$F=2.0703$

$\mathrm{P}=.576$

$P=.447$

$\mathrm{P}=.217$

$\mathrm{P}=.202$

No significance.

Results of presidents' self-perception presented in Tables 4-11 through 4-14 show that leadership frame does not differ with age, job tenure, school status, or school size.

1. Age (Less Than or 44 ; Over 44 years)

Table 4-11

Presidents' Age and Type of Frames (Presidents' Perception)

\begin{tabular}{lllllll}
\hline Which Frame? & Presidents' Age & N & M & SD & t-Value & P-Value
\end{tabular}

\begin{tabular}{|c|c|c|c|c|c|c|c|}
\hline \multirow{2}{*}{ Structural } & \multicolumn{2}{|c|}{ Under or 44} & 1 & \multicolumn{2}{|l|}{3.5833} & \multirow[t]{2}{*}{.07} & \multirow[t]{2}{*}{.943} \\
\hline & Over & 44 & 9 & 3.5602 & .300 & & \\
\hline Human & \multicolumn{2}{|c|}{ Under or 44} & 1 & 3.4792 & & \multirow[t]{2}{*}{-.61} & \multirow[t]{2}{*}{.552} \\
\hline Resource & Over & 44 & 12 & 3.6649 & .291 & & \\
\hline \multirow[t]{2}{*}{ Political } & \multicolumn{2}{|c|}{ Under or 44} & 1 & 3.2500 & & \multirow[t]{2}{*}{-.57} & \multirow[t]{2}{*}{.583} \\
\hline & Over & 44 & 10 & 3.4042 & .258 & & \\
\hline Symbolic & \multicolumn{2}{|c|}{ Under or 44} & $\begin{array}{l}1 \\
8\end{array}$ & $\begin{array}{l}3.5208 \\
3.7656\end{array}$ & .193 & -1.19 & .272 \\
\hline
\end{tabular}

No significance. 
2. The Time on the Job (under or 6 ; over 7 )

Table 4-12

Presidents' Job Tenure and Type of Frame (Presidents' Perception)

\begin{tabular}{|c|c|c|c|c|c|c|}
\hline Which Frame? & Presidents' Tenure & $\mathbf{N}$ & $\mathbf{M}$ & SD & $\mathrm{t}$-Value & P-Value \\
\hline \multirow[t]{2}{*}{ Structural } & Under or 6 & 3 & 3.6736 & .107 & 1.15 & .285 \\
\hline & Over 7 & 7 & 3.5149 & .328 & & \\
\hline Human & Under or 6 & 3 & 3.4931 & .024 & -1.11 & .291 \\
\hline Resource & Over 7 & 10 & 3.6971 & .310 & & \\
\hline \multirow{2}{*}{ Political } & Under or 6 & 2 & 3.1875 & .088 & -1.32 & .220 \\
\hline & Over 7 & 9 & 3.4352 & .253 & & \\
\hline \multirow[t]{2}{*}{ Symbolic } & Under or 6 & 1 & 3.6250 & -.58 & .580 & \\
\hline & Over 7 & 8 & 3.7526 & .207 & & \\
\hline
\end{tabular}

No significance.

3. School Status (public; private)

Table 4-13

Which Frames Do Presidents Use? (Presidents' Perception)

\begin{tabular}{|c|c|c|c|c|c|c|}
\hline Which Frame? & School Status & $\mathbf{N}$ & $\mathrm{SD}$ & t-Value & $\mathrm{P}-\mathrm{Va}$ & \\
\hline \multirow[t]{2}{*}{ Structural } & Public & 2 & 3.4375 & .295 & \multirow[t]{2}{*}{-.68} & \multirow[t]{2}{*}{.517} \\
\hline & Private & 8 & 3.5938 & .291 & & \\
\hline Human & Public & 2 & 3.5625 & .236 & -.46 & .653 \\
\hline Resource & Private & 11 & 3.6667 & .298 & & \\
\hline \multirow[t]{2}{*}{ Political } & Public & 0 & & & & \\
\hline & Private & 11 & 3.3902 & .249 & & \\
\hline \multirow[t]{2}{*}{ Symbolic } & Public & 1 & 3.5417 & .197 & -1.06 & .325 \\
\hline & Private & 8 & 3.7630 & & & \\
\hline
\end{tabular}

No significance. 
4. School Size (under $3000 ; 3001-5000$; over 5001 students)

Table 4-14

Which Frames Do Presidents Use? (Presidents' Perception)

\begin{tabular}{lcccccc}
\hline Which Frame? & School Size & N & M & SD & F-Value & P-Value \\
& & & & & & \\
Structural & $3001-5000$ & 6 & 3.5938 & .0583 & .9438 \\
& over 5001 & 11 & 3.1572 & & \\
under 3000 & 3 & 3.4375 & & & \\
Human & under 3000 & 3 & 3.5625 & 1.1873 & .5446 \\
Resource & $3001-5000$ & 6 & 3.6667 & & \\
& over 5001 & 11 & 3.5644 & & \\
Political & under 3000 & 3 & 3.1250 & 1.1839 & .3545 \\
& $3001-5000$ & 6 & 3.3902 & & \\
& over 5001 & 11 & 2.9545 & & \\
Symbolic & under 3000 & 3 & 3.5417 & .5440 & .6066 \\
& $3001-5000$ & 6 & 3.7630 & & \\
& over 5001 & 11 & 3.2841 & & & \\
& & & & & &
\end{tabular}

No significance.

Results presented in Table 4-15 show no relationship between leadership frame and presidents' age, job tenure, school status, or school size. 
Table 4-15

The Mean of How Many Frames the President Uses

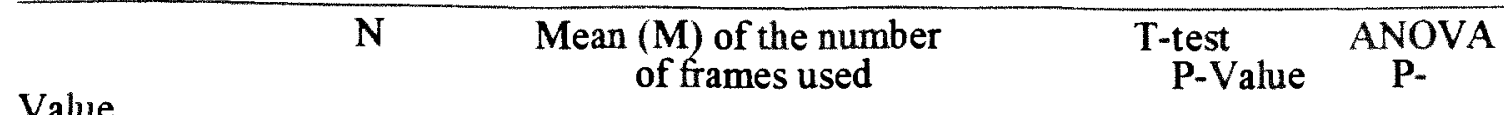

Age

1. under 44

2

2.00

2. over 45

18

2.17

.850

Time on Job

1. under 6

2. over 7

5

1.80

2.27

School status

1. public

3

1.67

2. Private

17

2.24

School size

1. $<3000$

3

.9852

2. $3001-5000$

6

2.67

3. over 5001

11

2.00

No significance.

Subsidiary Question TwQ: Do teachers' perceptions of job satisfaction vary significantly with teachers' gender, age, job tenure, educational background, academic, school status, and school size? Specific aspects of job satisfaction included teaching itself, school environment, administration/supervision, job remuneration, and promotion. The results of the t-tests showed a significant difference between school status and only two of the job satisfaction measures: job remuneration and promotion. Teachers in public schools were more satisfied with these aspects than were teachers in private schools (Table 4-16). 
1. School Status:

Table 4-16

T-test for Subscales of Job Satisfaction on School Status

\begin{tabular}{|c|c|c|c|c|c|}
\hline & \multicolumn{2}{|c|}{ Public } & \multicolumn{2}{|c|}{ Private } & \multirow{2}{*}{$\begin{array}{l}\text { t-test } \\
\text { P-Value }\end{array}$} \\
\hline & $\mathbf{M}$ & SD & $\mathbf{M}$ & SD & \\
\hline Teaching Work & 3.8431 & .7553 & 3.7246 & 5438 & .292 \\
\hline School Esvironment & 3.6005 & .6796 & 3.6266 & .4638 & .795 \\
\hline $\begin{array}{c}\text { Administration } \\
\text { Supervision }\end{array}$ & 3.9020 & .7758 & 3.6739 & .6071 & .053 \\
\hline Job Remuneration & 3.7304 & .7033 & 3.4843 & .6163 & $.013^{*}$ \\
\hline Promotion & 3.8505 & .6680 & 3.6261 & .5127 & $.027^{*}$ \\
\hline
\end{tabular}

${ }^{*} \mathrm{p}<.05 ;$ two-tailed test

School Size. Results show a relationship between school size and teaching, school environment, administration/supervision, job remuneration, and promotion (Table 4-17).

Teachers in large colleges (5000 or more students) were more satisfied with school environment, administration/supervision, job remuneration, and promotion than were teachers in schools with 3001 to 5000 students (Tables 4-18 to 4-21). 
Table 4-17

ANOVA for Subscales of Job Satisfaction on School Size

\begin{tabular}{lcc}
\hline & \multicolumn{2}{c}{ School Size } \\
& F value & P Value \\
\hline Teaching Work & 3.0580 & $.0486^{*}$ \\
School Environment & 7.2386 & $.0009^{* *}$ \\
Administration Supervision & 3.2026 & $.0422 *$ \\
Job Remuneration & 3.2899 & $.0387^{*}$ \\
Promotion & 3.8700 & $.0220^{*}$ \\
\hline$* \mathrm{p}<.05 ; * * * \mathrm{p}<.001$ & & \\
\hline
\end{tabular}

The Scheffe's test for comparing contrasts indicated that, in terms of school size and teaching, no two groups were significantly different at the .05 level of significance. However, there were significant group differences when satisfaction with school environment, administration/supervision, job remuneration, and promotion was analyzed by school size. Teachers in schools with over 5000 students were more satisfied with the school's environment, administration/supervision, job remuneration, and promotion than schools with 3001 to 5000 students (See Tables 14-18 through 14-21). 
Table 4-18

Multiple Comparison of School Environment on School Size

\begin{tabular}{llcll}
\hline Mean & School Size & Grp 2 & Grp 1 & Grp 3 \\
3.4954 & Grp 2 & & & \\
3.6005 & Grp 1 & & & \\
3.7439 & Grp 3 & $*$ & &
\end{tabular}

Note. Grp $1=$ under or $3000 ;$ Grp $2=3001-5000 ;$ Grp $3=5001$ or more.

Table 4-19

Multiple Comparison of Administration Supervision on School Size

Mean School Size Grp 2 Grp 1 Grp 3

3.5963 Grp 2

3.7495 Grp 1

3.8069 Grp 3

Note. Grp $1=$ under or $3000 ;$ Grp $2=3001-5000$; Grp $3=5001$ or more.

Table 4-20

Multiple Comparison of Job Remuneration on School Size

$\begin{array}{llccc}\text { Mean } & \text { School Size } & \text { Grp 2 } & \text { Grp 1 } & \text { Grp 3 } \\ 3.4232 & \text { Grp 2 } & & & \\ 3.5000 & \text { Grp 1 } & & & \\ 3.6352 & \text { Grp 3 } & * & & \end{array}$

Note. Grp $1=$ under or $3000 ;$ Grp $2=3001-5000 ;$ Grp 3 = 5001 or more.

Table 4-21

Multiple Comparison of Promotion on School Size

$\begin{array}{llccc}\text { Mean } & \text { School Size } & \text { Grp 2 } & \text { Grp 1 } & \text { Grp 3 } \\ 3.5642 & \text { Grp 2 } & & & \\ 3.6544 & \text { Grp 1 } & & & \\ 3.7633 & \text { Grp 3 } & * & & \end{array}$

Note. Grp $1=$ under or 3000; Grp 2=3001 -5000; Grp 3 = 5001 or more. 
3. Sex

As portrayed in Table 4-22, there was a significant difference in gender and satisfaction with school environment, administration/supervision, and job remuneration. There was no difference in gender and satisfaction with teaching itself and promotion. In all cases, the mean for male teachers were higher than the means for female teachers.

Table 4-22

T-test for Subscales of Job Satisfaction on Gender

\begin{tabular}{lccccc}
\hline & \multicolumn{2}{c}{ Males $(\mathrm{N}=190)$} & \multicolumn{2}{c}{ Females $(\mathrm{N}=92)$} & t-test \\
& $\mathrm{M}$ & $\mathrm{SD}$ & $\mathrm{M}$ & $\mathrm{SD}$ & $\mathrm{P}-$ Value \\
& & & & & \\
\hline Teaching Work & 3.7599 & .5678 & 3.7174 & .6298 & .570 \\
School Environment & 3.6678 & .4894 & 3.5272 & .5358 & $.029 *$ \\
Administration Supervision & 3.7848 & .6240 & 3.5713 & .6680 & $.009 * *$ \\
Job Remuneration & 3.5868 & .6391 & 3.4090 & .6243 & $.028^{*}$ \\
Promotion & 3.6730 & .5488 & 3.6535 & .5541 & .781 \\
\hline${ }^{*} \mathrm{p}<.05 ;{ }^{*} \mathrm{p}<.01 ;$ two-tailed test & & & & & \\
\hline
\end{tabular}

4. Age

There was no difference in age and three measures of job satisfaction: teaching itself, job remuneration, and promotion. There was a significant difference in age and environment, but no two groups differed significantly at the .05 level. Satisfaction with administration/supervision differed significantly with age. As Table 
4-24 shows, 40 to 59 year old teachers (groups 3 and 4) were more satisfied with administration or supervision than were teachers under 29 years of age; also, 50 to 59 year olds were more satisfied on this job satisfaction measure than were 30 to 39 year olds.

Table 4-23

ANOVA for Subscales of Job Satisfaction on Age

\section{Age \\ F Value P Value}

Teaching Work

$1.0682 \quad .3725$

School Environment

$2.5062 \quad .0424^{*}$

Administration Supervision

$6.9765 .0000 * * *$

Job Remuneration

2.3992

.0504

Promotion

1.9148

.1081

Table 4-24

Multiple Comparison of Administration Supervision on Age

Mean Age Grp 1 Grp 2 Grp 3 Grp 5 Grp 4

3.4412 Grp 1

3.6578 Grp 2

3.8868 Grp 3

3.8889 Grp 5

4.3407 Grp 4

Note. Grp $1=$ under or 29 years old; Grp 2=30-39; Grp 3 $=40-49$ Grp $4=50-59 ; \quad$ Grp $5=60$ years old or over. 
5. Tenure or Length of Service (including this year):

There was no difference in length of service and four of the job satisfaction measures: teaching itself, school environment, job remuneration, promotion. There was a difference in length of service and satisfaction with administration or supervision, as Table 4-25 shows.

Table 4-25

ANOVA for Subscales of Job Satisfaction on Length of Service (Tenure)

\begin{tabular}{lcc}
\hline & \multicolumn{2}{c}{ Length of Service } \\
& F Value & P Value \\
\hline Teaching Work & 1.6874 & .1530 \\
School Environment & 1.5884 & .1775 \\
Administration Supervision & 2.9005 & $.0224^{*}$ \\
Job Remuneration & .9924 & .4120 \\
Promotion & 1.9145 & .1082 \\
\hline
\end{tabular}

${ }^{*} \mathrm{p}<.05$

Scheffe test showed that teachers who had been employed for 21 or more years were more satisfied with administration and supervision than were those who had been employed three years or less (See Table 4-26). 
Table 4-26

Multiple Comparison of Administration Supervision on Tenure

\begin{tabular}{lllllll}
\hline Mean & $\begin{array}{l}\text { Length of } \\
\text { Service }\end{array}$ & Grp 1 & Grp 2 & Grp 4 & Grp 3 & Grp 5 \\
3.6021 & Grp 1 & & & & & \\
3.6904 & Grp 2 & & & & & \\
3.8194 & Grp 4 & & & & & \\
3.8429 & Grp 3 & $*$ & & & & \\
4.0944 & Grp 5 & $*$ & & & &
\end{tabular}

Note. Grp 1 =1 - 3; Grp 2=4 - 10; Grp 3=11 - 15;

Grp $4=16-20 ;$ Grp $5=21$ years or more.

6. Educational Level:

Educational level. There was no difference in the measures of job satisfaction and educational level (Table 4-27).

Table 4-27

ANOVA for Subscales of Job Satisfaction on Educational Level

\begin{tabular}{lcc}
\hline & \multicolumn{2}{c}{ Educational Level } \\
& F Value & P Value \\
\hline Teaching Work & .8853 & .4731 \\
School Environment & 2.1516 & .0747 \\
Administration Supervision & 1.1898 & .3155 \\
Job Remuneration & 1.0478 & .3829 \\
Promotion & .2648 & .9004 \\
\hline
\end{tabular}

None of these is significant 
7. Academic Rank

There was a difference in academic rank and four measures of job satisfaction: teaching, administration or supervision, job remuneration, promotion (Table 4-28). Professors were more satisfied with teaching, administration/supervision, and promotion than were assistants. Associate professors and instructors were more satisfied with promotion than were assistants (See Tables 4-29 to 4-31).

Table 4-28

ANOVA for Subscales of Job Satisfaction on Academic Rank

\begin{tabular}{lcc}
\hline & \multicolumn{2}{c}{ Academic Rank } \\
& F Value & P Value \\
\hline Teaching Work & 3.0064 & $.0188^{*}$ \\
School Environment & 1.8672 & .1164 \\
Administration Supervision & 4.4887 & $.0016^{* *}$ \\
Job Remuneration & 3.0823 & $.0166^{*}$ \\
Promotion & 5.7515 & $.0002 * * *$ \\
\hline
\end{tabular}

$$
{ }^{*} \mathrm{p}<.05 ;{ }^{* *} \mathrm{p}<.01 ;{ }^{* * *} \mathrm{p}<.001
$$


Table 4-29

Multiple Comparison of Teaching Work on Academic Rank

Mean Position Grp 5 Grp 4 Grp 2 Grp 3 Grp 1

3.3972 Grp 5

3.7396 Grp 4

3.8257 Grp 2

4.0000 Grp 3

4.1667 Grp 1

Note. Grp 1 = Professor; $\quad$ Grp 2 = Associate Professor; $\quad$ Grp 3 = Assistant Professor; Grp 4 = Instructor; Grp 5=Assistant.

Table 4-30

Multiple Comparison of Administration Supervision and Academic Rank

\begin{tabular}{lllllll}
\hline Mean Position Grp 5 & Grp 4 & Grp 3 & Grp 2 & Grp 1
\end{tabular}

3.4379 Grp 5

3.6667 Grp 4

3.9444 Grp 3

3.9737 Grp 2

4.2593 Grp 1

Note. Grp 1 = Professor; Grp 2 = Associate Professor; Grp 3 = Assistant Professor; Grp 4 = Instructor; Grp 5 = Assistant.

The Scheffe test showed that professors were more satisfied with teaching itself, administration/supervision, and promotion than were assistants (Table 4-29 and 4-30). Associate professors and instructors were more satisfied with promotion than were assistants (Table 4-31). 
Table 4-31

Multiple Comparison of Promotion on Academic Rank

Mean Position Grp 5 Grp 4 Grp 2 Grp 3 Grp 1

3.1985 Grp 5

3.6597 Grp 4

3.7928 Grp 2

3.8125 Grp 3

4.1528 Grp 1

Note. Grp 1 = Professor; Grp 2 = Associate Professor; Grp 3 = Assistant Professor; Grp 4 = Instructor; Grp 5= Assistant.

8. Administrative Task:

Administrative task differed only with administration/supervision subscale of job satisfaction. Teachers with administrative tasks were more satisfied with administration/supervision than were teachers with no administrative tasks. There was no difference in administrative task and four subscales of job satisfaction: teaching itself, school environment, job remuneration, and promotion (Table 4-32). 
Table 4-32

T-test for Subscales of Job Satisfaction on Administrative Task

\begin{tabular}{lccccc}
\hline & \multicolumn{2}{c}{ Yes } & \multicolumn{2}{c}{ No } & t-test \\
& & SD & M & SD & P-Value \\
\hline Teaching Work & 3.7618 & .6031 & 3.7348 & .5786 & .706 \\
School Environment & 3.6442 & .4879 & 3.6061 & .5232 & .535 \\
Administration Supervision & 3.8196 & .6487 & 3.6411 & .6346 & $.022^{*}$ \\
Job Remuneration & 3.5470 & .6373 & 3.5159 & .6413 & .688 \\
Promotion & 3.6859 & .5425 & 3.6530 & .5558 & .622 \\
\hline
\end{tabular}

${ }^{*} \mathrm{p}<.05 ;$ two-tailed test 
Table 4-33

Summary of Results:

T-Tests for Subscales of Job Satisfaction on Sex, Administrative Task, School Status

\begin{tabular}{|c|c|c|c|}
\hline & Sex & Administrative task & School Status \\
\hline & Female & Yes & Public Private \\
\hline $\begin{array}{l}\text { Teaching Work } \\
\text { (t-test) }\end{array}$ & $\begin{array}{c}3.75993 .7174 \\
(.570)\end{array}$ & $\begin{array}{c}3.76183 .7348 \\
(.706)\end{array}$ & $\begin{array}{c}3.84313 .7246 \\
(.292)\end{array}$ \\
\hline $\begin{array}{l}\text { School Environment } \\
\text { (t-test) }\end{array}$ & $\begin{array}{c}3.6678 \quad 3.5272 \\
(.029)^{*}\end{array}$ & $\begin{array}{c}3.64423 .6061 \\
(.535)\end{array}$ & $\begin{array}{c}3.60053 .6266 \\
(.795)\end{array}$ \\
\hline $\begin{array}{l}\text { Administrative Supervision } \\
\text { (t-test) }\end{array}$ & $\begin{array}{c}3.7848 \quad 3.5713 \\
(.009)^{* *}\end{array}$ & $\begin{array}{c}3.81963 .6411 \\
(.022)^{*}\end{array}$ & $\begin{array}{c}3.90203 .6739 \\
(.053)\end{array}$ \\
\hline Job Remuneration & $3.5868 \quad 3.4090$ & $3.5470 \quad 3.5159$ & $3.7304 \quad 3.4843$ \\
\hline (t-test) & $(.028)^{*}$ & $(.688)$ & $(.013)^{*}$ \\
\hline $\begin{array}{l}\text { Promotion } \\
\text { (t-test) }\end{array}$ & $\begin{array}{c}3.67303 .6535 \\
(.781)\end{array}$ & $\begin{array}{c}3.68593 .6530 \\
(.622)\end{array}$ & $\begin{array}{c}3.85053 .6261 \\
(.027)^{*}\end{array}$ \\
\hline
\end{tabular}

${ }^{*} \mathrm{P}<.05 ;{ }^{* *} \mathrm{P}<.01 ;{ }^{* * *} \mathrm{p}<.001$ 
Table 4-34

Summary of Results:

ANOVA for Subscales of Job Satisfaction on Age, Tenure, Educational Level, Academic, School Size

\begin{tabular}{|c|c|c|c|c|c|}
\hline & Age & Tenure & $\begin{array}{c}\text { Educational } \\
\text { Level }\end{array}$ & $\begin{array}{r}\text { Academic } \\
\text { Rank }\end{array}$ & School Size \\
\hline Teaching & $F=1.0682$ & $F=1.6874$ & $F=.8853$ & $F=3.0064$ & $F=3.0580$ \\
\hline Work & $\mathrm{P}=.3725$ & $P=1530$ & $P=4731$ & $P=0188^{*}$ & $\mathrm{P}=.0486^{*}$ \\
\hline School & $F=2.5062$ & $F=1.5884$ & $F=2.1516$ & $F=1.8672$ & $F=7.2386$ \\
\hline Environment & $\mathrm{P}=.0424^{*}$ & $\mathrm{P}=1775$ & $P=.0747$ & $P=.1164$ & $\mathrm{P}=.0009^{* * *}$ \\
\hline Administrative & $F=6.9765$ & $F=2.9005$ & $F=1.1898$ & $F=4.4887$ & $F=3.2026$ \\
\hline Supervision & $\mathrm{P}=.0000^{* * *}$ & $\mathrm{P}=.0224^{*}$ & $\mathrm{P}=.3155$ & $\mathrm{P}=.0016^{* *}$ & $\mathrm{P}=.0422^{*}$ \\
\hline Job & $F=2.3992$ & $F=.9924$ & $F=1.0478$ & $F=3.0823$ & $F=3.2899$ \\
\hline Remuneration & $\mathrm{P}=.0504$ & $\mathrm{P}=.4120$ & $\mathrm{P}=.3829$ & $\mathrm{P}=.0166^{*}$ & $\mathrm{P}=.0387^{*}$ \\
\hline Promotion & $F=1.9148$ & $F=1.9145$ & $F=.2648$ & $\mathrm{~F}=5.7515$ & $F=3.8700$ \\
\hline & $\mathrm{P}=.1081$ & $\mathrm{P}=.1082$ & $P=.9004$ & $\mathrm{P}=.0002 * * *$ & $\mathrm{P}=.0220^{*}$ \\
\hline
\end{tabular}

\section{Summary of Results}

Analysis of data for question one showed that the difference between teacher perception of the type of frame ( structural, human resource, political, symbolic) and general job satisfaction is not significant. However, teachers who thought their presidents used multiple frames were more satisfied than were teachers who thought their presidents used single frames. Regarding question two, the results of a Chi-Square test indicated that there was congruence between teacher and president perceptions of the type and number 
of leadership frames the president used. Analysis of data for question three indicated that presidents' leadership frame did not differ with presidents' age, job tenure, school size, or school status.

Results for question four showed a difference between school size and teacher satisfaction with teaching, school environment, administration/supervision, job remuneration, and promotion. Results showed: 1) no significant difference in gender and satisfaction with teaching and promotion; 2) no difference in age and satisfaction with teaching, job remuneration, and promotion; 3 ) no difference in length of service and satisfaction with teaching, school environment, job remuneration, and promotion; 4) no difference in educational level and any of the subscales of job satisfaction; 5) a difference in academic rank and teaching, administration/supervision, job remuneration, and promotion; 6) a difference in administrative task and satisfaction with administration/supervision; 7) a difference in school status and job remmeration, promotion. These findings are discussed in the next chapter. 


\section{CHAPTER FIVE}

\section{SUMMARY, CONCLUSIONS, AND RECOMMENDATIONS}

\section{Summary}

\section{Purpose of Study}

This dissertation had two purposes. The first was to investigate the relationship between the leadership styles of Taiwanese junior college presidents and teacher job satisfaction. The second was to determine the degree of agreement between teacher perception of presidents' frame and presidents' self-perception. Bolman and Deal's (1991) four frames leader orientation (structural, human resource, political, symbolic) provided the theoretical perspective for the study. Smith, Kendall, and Hulin's (1969, 1985) Job Description Index (JDI) provided the operational definition of job satisfaction as general job satisfaction and satisfaction with such specific aspects as the job itself, pay, promotion, supervision, and coworkers.

\section{Review of Pertinent Literature}

A review of the literature on the subjects of leadership style, job satisfaction, and teacher/president relationships resulted in identifying in formation pertinent to this study. This information included various leadership styles, principles of job satisfaction and dissatisfaction, and evidence that indicated a relationship between the president's leadership behavior and teachers' job satisfaction. The relationships that a teacher has with others in the school setting can either enhance or limit the opportunities to achieve 
intrinsic rewards. Presidents who closely supervise, hardly ever praise, and usually criticize the job teachers perform, greatly decrease the autonomy and authority teachers need in order to solve their own problems and foster effective relationships with others.

\section{Design and Methodology}

The target population for this study included all presidents and full-time teachers of Taiwan's junior colleges. Random sampling yielded 24 presidents; convenient sampling yielded 403 teachers. Each participating teacher completed the teachers' instrument (President's Leadership Orientations and Teachers Job Satisfaction Questionnaire); each president completed the presidents' instrument (President's Leadership Orientations). The President's Leadership Orientations Questionnaire was used to determine teachers' perception and presidents' self-perception of presidents' leadership frame. In addition, it was used to determine the congruence between teacher and president perception. The Teachers' Job Satisfaction Questionnaire was used to determine job satisfaction of teachers. Demographic data were also obtained from presidents and teachers.

\section{Research Questions}

The four research questions were: 1) What is the relationship between teachers' perception of their presidents' leadership style frame and teachers' general job satisfaction? The study operationalized teachers' perception of leadership frames as the 
number and type of frames used by presidents. 2) What is the degree of agreement between teachers' perception of presidents' frame and presidents' self-perception? 3) Does a president's leadership style vary with age, tenure, school status, and school size? 4) Do teachers' perception of job satisfaction vary with teachers' gender, age, job tenure, educational background, academic position, school status, and school size?

\section{Findings}

The findings of the study were obtained through an analysis of the obtained data reported by teachers and presidents. After the questionnaires were scored and the data tabulated, the results were used to respond to the research questions of this study. The research questions were addressed through the use of t-tests, ANOVA, Chi Square, and Scheffe's test for comparing contrasts. Descriptive analyses yielded frequencies, percentages, means, and standard deviations. All results were tested at the 0.05 level of significance.

Analysis of data for question one showed that the relationship between teacher perception of the type of frame (structural, human resource, political, symbolic) and general job satisfaction was not significant. However, teachers who thought their presidents used multiple frames were more satisfied than teachers who thought their presidents used single frames. Regarding question two, the results of a Chi-Square test indicated that there was congruence between teacher and president perceptions of the type and number of leadership frames the presidents used. Analysis of data for question 
three indicated that presidents' leadership frame did not differ with presidents' age, job tenure, school size, or school status.

Results for question four showed a difference in school size and teacher satisfaction with teaching, school environment, administration or supervision, job remuneration, and promotion. Additionally, results showed: 1) a significant difference in gender and satisfaction with teaching and promotion; 2 ) no difference in age and satisfaction with teaching job remuneration, and promotion; 3) no difference in length of service and satisfaction with teaching, school environment, job remuneration, and promotion; 4) no difference in educational level and any of the measures of job satisfaction; 5) a difference in academic rank and teaching, administration/supervision, job remuneration, and promotion; 6) a difference in administrative task and satisfaction with administration/supervision.

\section{Discussion of the Findings}

The main purpose of this study was to determine the relationship between the leadership style of junior college presidents and teacher job satisfaction. Leadership style was operationalized as Bolman and Deal's four frames: structural, human resource, political, and symbolic. Job satisfaction was operationalized in terms of Smith, Kendall, and Hulin's Job Description Index: general job satisfaction and the five sub scales of job satisfaction (the job itself, pay, promotion, supervision, coworkers). 
The relationships between leadership style and four variables were examined. Two were institutional variables (school size and school status) and two were personal variables (president's age and job tenure). The relationships between teacher perception of job satisfaction and seven variables were examined. Two were institutional variables (school size and status) and five were personal variables (teacher's gender, age, job tenure, educational background, academic rank). Additionally, the study determined the degree of agreement between teachers' perception of presidents' frame and presidents' self-perception. The study defined perception of leadership frame as the number and type of frames the presidents used.

\section{General Job Satisfaction and Leadership Style}

General job satisfaction was related to the number of frames presidents used, but not to the type of frame. Two-frame style received the highest frequency. Ninety-four teachers (one-third of the sample) indicated that their presidents used two frames. Thirty-one teachers indicated that their presidents used none of the four frames. This suggests that, perhaps, for those teachers, the presidents leadership style was unclear or imprecise. It may also suggest that Bolman and Deal's framework does not capture all possible leadership frames of the presidents of Taiwan's junior colleges. Perceived use of one, three, and four frames received relatively equal frequencies.

Teachers whose presidents use more than one frame were more satisfied than were teachers whose presidents use one frame. This finding supports Bolman and Deal's 
(1991) and Bensimon $(1988,1989)$ conclusion that multiframe college presidents are more effective than single-frame presidents. The result of the present study supports the finding of a positive relation between president leadership effectiveness and teacher job satisfaction. General job satisfaction increases with the number of frames used. Teachers whose presidents use none of the four frames were least satisfied; these presidents are younger and have shorter tenure. They are also from small public schools. Teachers whose presidents use all four frames were most satisfied.

General job satisfaction did not relate to the type of frame used by presidents. Three of the frames (human resource, political, symbolic) received almost equal frequencies. Structural frame was lower, suggesting that presidents are not applying flexible, participative, leadership styles.

\section{Congruence of Perceptions}

Research question two addressed the degree of agreement between teacher perception and president self-perception. Analysis of the data reveals congruence between teacher and president perception. The difference in president and teacher perception of the type and number of frame presidents use is not significant. Bensimon $(1988,1989)$ found that presidents reported that they used more frames than teachers reported for the same presidents. The finding of the present study suggests that Taiwanese presidents may have a realistic awareness of their own leadership styles and skills or that they are conservative or modest, and, therefore, do not inflate their attributes in self- reports. 


\section{Leadership Style and Presidents' Demographics}

Research question three sought to determine the relationship between leadership frame and two institutional and two personal variables. The analysis of the data shows that leadership frames used do not vary significantly with the institutional and personal factors of school status and size, and president's age and job tenure. However, detailed analysis shows that older, longer tenured presidents from private, mid-sized (3001-5000 students) colleges indicated that their presidents use more leadership frames.

\section{Job Satisfaction and Teacher Demographics}

Research question four addresses the differences in teacher job satisfaction and two institutional variables (school status and size) and six personal variables (gender, age, job tenure, educational background, academic rank, administrative task). Specific aspects of job satisfaction included teaching itself, school environment, administration/supervision, job remuneration, and promotion. The findings are discussed next.

\section{Institutional Variables}

School Status. There were three public and 17 private schools in this study. Analysis of the data showed a significant difference in school status and job remuneration and promotion. Teachers in public junior colleges were more satisfied with pay and promotion than were teachers in private colleges. This reflects the tendency of Taiwan's public colleges to pay more than do private schools and the tendency for public schools to 
have better, fairer promotion systems than private schools. Satisfaction with teaching, school environment, and administration or supervision does not vary with school status.

School Size. Satisfaction with all five job satisfaction subscales (teaching, school environment, administration/supervision, remuneration, promotion) varies with school size. Teachers in colleges with more than 5000 students were more satisfied with school environment, administration/supervision, job remuneration, and promotion than were teachers in colleges with 3001 to 5000 students.

\section{Personal Variables}

Gender. Gender relates to satisfaction with administration/supervision, school environment, and job remuneration. The difference in gender and satisfaction with teaching and promotion is not significant. In all cases, male professors were more satisfied than were female professors. Teaching is a major career for Taiwanese men; they give much more time, effort, and attention to teaching than do women, who must spend much of their energies on housework and childcare. Men also have more opportunities for administrative and supervisory positions and more opportunities for advancement and higher salaries.

Age. Teachers' age differs with satisfaction with administration/supervision and school environment. Age does not differ with satisfaction with teaching, job remuneration, and promotion. Teachers between the ages of 40 and 59 were more satisfied with administration and supervision than were teachers who are under 29 years of 
age. Teachers between the ages of 50 and 59 were more satisfied with supervision and administration than were teachers between the ages of 30 and 39. Teachers 60 years and older were satisfied, probably because they look forward to retirement with pleasant anticipation.

Tenure or length of service. Length of service differs with satisfaction with administration or supervision. Length of service does not differ with satisfaction with teaching, school environment, job remuneration, and promotion. Those who had taught 21 or more years were more satisfied than were those who had taught for fewer years. Those who had taught for a longer time usually had more opportunities for administrative/supervisory tasks.

Educational level. Analysis of data revealed that the educational level of teacher has no bearing on any of the five measures of job satisfaction. This finding suggests that a teacher's educational level is not a good predictor of job satisfaction.

Academic rank. Academic rank differs with teaching itself, job remuneration, administration/supervision, and promotion. Professors were more satisfied with teaching itself, administration/supervision, and promotion than were assistants. Associate professors and instructors are more satisfied with promotion than were assistants. There is not a significant difference in rank and school environment. This finding suggests that professors with higher academic rank have more opportunities to participate in decision making, are more respected by students and their parents, are rewarded more, and have more opportunities for advancement. 
Administrative task. The administrative task differed with satisfaction with administration or supervision. Teachers with administrative tasks were more satisfied with administration or supervision than were teachers with no administrative tasks. There was no difference in satisfaction with administrative task and teaching, school environment, job remuneration, and promotion.

\section{Conclusions of the Study}

The findings of this study suggest the following conclusions. 1) The number of frames used by the president is a significant predictor of general job satisfaction. Teachers who perceived their presidents as using none of the four frames are the least satisfied. Teachers who perceived their presidents as using all four frames are the most satisfied. 2) Taiwanese presidents may be realistically aware of their abilities or they may be conservative; therefore, their self-reports are congruent with assessments made by professors of their colleges. 3) Presidents' age, job tenure, school size, and school status are not significant predictors of leadership frames used. 4) School size is a significant predictor of satisfaction with teaching, school environment, administration or supervision, reward system, and promotion. 5) Gender is a significant predictor of satisfaction with teaching and promotion. 6) Academic rank is a good predictor of satisfaction with teaching, administration or supervision, rewards, and promotion. 7) Administrative job is a good predictor of satisfaction with administration/supervision. 8) Age is a significant predictor of satisfaction with school environment and administration/supervision. 9) 
Tenure is a significant predictor of satisfaction with administration/supervision. 10) Level of education is not a significant predictor of satisfaction with teaching, reward system, promotion, supervision or administration, and school environment.

Implications for Research and Practice

Implications for Research

Additional research should take this study one step further by linking teacher job satisfaction to teacher performance and student academic performance. Also, variables that are significant should be subjected to additional studies with other populations. For example, top, middle, and lower college administrators and supervisors could be studied just as presidents were studied here. Students and staff members could be included, in addition to teachers. Outside interest groups and supporters of the colleges could also be studied; for example, college board members and alumi. Variables that are not significant predictors of satisfaction should be analyzed further to determine why they are not significant. Interviews with some of the respondents may be able to enlighten this type of investigation.

\section{Implications for Practice}

College presidents and all administrators should be aware of the importance of teacher job satisfaction and the variables that predict job satisfaction. College leaders should make deliberate efforts to learn about leadership effectiveness and the impact of 
leadership style on job satisfaction. Going an additional step, college leaders should try to understand the impact of teacher job satisfaction on teacher performance and student academic performance. College presidents should take Bolman and Deal's advice that the four leadership frames should be used as tools for effective leadership, and that practice and experience with the frames or tools are important to attaining leadership skills.

\section{Recommendations for Future Research}

Researchers should conduct similar studies to try to determine how many frames and which frames are important to other junior college leaders, administrators, and school board members. Researchers should also conduct similar studies using different research instruments that might include personal interviews with the teachers, presidents, and other categories of staff.

\section{Recommendations for Practice}

The following recommendations were made as a result of this study. The satisfaction, motivation, and human relations aspects of teaching need to be considered by all school administrators. Presidents are urged to develop meaningful two-way communication with their teachers. Effective ways of communication include reinforcing words with action, using multiple communication channels, using verbal and nonverbal feedback, appealing to human motivation, using nonsexist language, and avoiding information overload. 
Presidents should develop programs to monitor teacher satisfaction and dissatisfaction, and to train teachers and administrators in interpersonal relations. These programs should be a high priority item in staff development activities. Presidents should become more familiar with motivational theory. All presidents should be encouraged to attend human relations workshops or seminars to enhance their motivation and leadership techniques.

Good educational leadership can be developed through systematic training. Continuous development of leadership skills is part of any president's and top college administrator's agenda for professional growth and development. The skills will be maintained only if presidents and other college administrators update and widen their knowledge through continuous learning.

Universities should develop their curricula to transmit the common core of the new leadership knowledge and skills to students who are majoring in school administration, and train them to be both good followers and leaders. This researcher believes a good follower may not be a good leader but a good leader should be a good follower. An effective school administrator recognizes the responsibilities of the role he/she is playing in different situations.

The results of this study suggest that the symbolic frame is rarely used by Taiwan's junior college presidents. Taiwan's presidents should understand the usefulness of a variety of styles, and, more importantly, the usefulness of models of leadership that include a transformational, cultural, or symbolic leadership style. 
Taiwanese presidents are challenged to understand their abilities and competencies, to enhance them through the use of more than one frame, and to encourage teachers and other administrators to work together in teams that provide leadership in all four modes structural, human resource, political, and symbolic. The challenges brought about by rapid economic growth and development implies a new order of leadership for Taiwan's junior colleges which are responsible preparing for a sizable portion of the workforce.

Integrated leadership seems to be the key to productivity; therefore, presidents could enhance their capabilities by attending appropriate leadership seminars, workshops, and conferences; by exchanging ideas with colleagues in Taiwan and in other countries; by taking advantage of management consultants and experts; by experimenting with models of leadership that incorporate various frames. 


\section{REFERENCES}

Adams, J. S. (1979). Inequity in soil exchange. In R. M. Steers \& L. M. Porter (Eds.), Motivation and Work Behavior (2nd ed.). New York: McGraw-Hill.

Baird, L. S., Post, J. E., \& Mahon, J. F. Management functions and responsibilities. Grand Rapids, MI: Harper \& Row.

Balzer, W. K, Smith, P. C., Krivitz, D. E., Lovell, S. E., Paul, K. B., Reilly, B. A., \& Reilly, C. E. (1990). Users' manual for the job descriptive index. Bowling Green State University, Bowling Green, $\mathrm{OH}$.

Bass, B. M. (1981). Stogdill's Handbook of Leadership: A survey of theory and research. (Revised \& expanded ed. ). New York: Free Press.

Bensimon, E.M. (1989). The meaning of good presidential leadership: A frame analysis. Review of Higher Education. 107-123.

Bensimon, E.M. (1988). Viewing the presidency: Perceptual congruence between presidents and leaders on their campuses. Paper presented at the meeting of the American Educational Research Association, New Orleans.

Bolman, L. (1989). Leadership orientations. Unpublished manuscript, Harvard University.

Bolman, L. G. \& Deal T. E. (1991). Reframing organizations. San Francisco: Jossey-Bass.

Bolman, L. G. \& Deal T. E. (1994). Looking for leadership: Another search party's report. Educational Administration Quarterly, 30 (1), 77-96.

Bolman, L. G. \& Deal, T. E. (1991). Leadership and management effectiveness: A multi-frame, multi-sector analysis. Human Resource Management, 30 (4), 517-518.

Brodinsky, B. (1984). Teacher morale: What builds it, what kills it. Instructor, 93 (8), $36-38+$. 
Brodinsky, B. \& Neil, S. B. (1983). Building morale, motivating staff: Problems and solutions. (AASA Critical Issues Report) (ERIC Document Reproduction Service No. ED 227549). Sacramento, CA: Educational News Service.

Burns, J. (1978). Leadership. New York: Harper \& Row.

Campbell, J. P. (1970). Managerial behavior performance and effectiveness. New York: McGraw-Hill.

Chemers, M. W. (1984). The social, organizational, and cultural context of effective leadership. In Kellerman, B.(Ed.). Leadership: Multidisciplinary perspectives. Englewood Cliffs, NJ: Prentice-Hall.

Chu, I. Y. (1993). The relationship of teachers' job satisfaction and their perceptions of principals, leadership styles in private vocational high schools in a selected metropolitan area of Taiwan. Unpublished doctoral dissertation, University of Northern Iowa.

Coffey, R. E. (1975). Behavior in organizations.(2nd ed.). NJ: Prentice-Hall.

Collmer, J. (1989). A correlational study of principals' leadership styles and teachers' job satisfaction. Unpublished doctoral dissertation, East Texas State University.

Cranny, C. J., Smith, P. C., \& Stone, E. F. (1992). Job satisfaction. New York: Lexington Books.

Dinham, S. (1994, September). Enhancing the quality of teacher satisfaction. Paper presented at the national Conference of the Australian College of Education, Launceston, Tasmania, Australia (ERIC Document Reproduction Service No. ED 380409)

Dubrin, A. J. (1984). Human relations. Reston, VA: Reston Publishing Company.

Fibb, J. (1969). Dynamics of Leadership. In F. Carver \& T. Sergiovanni (Eds.), Organizations and human behavior: Focus on schools. New York: McGraw-Hill.

Fiedler, F. E. (1967). A theory of leadership effectiveness. New York: McGraw-Hill. 
Fox, W. M. (1986, November). Teacher motivation. Paper presented at the Annual Conference of the National Council of the State of Inservice Education, Nashville, TN (ERIC Document Reproduction Service No. ED 275677).

Gay, L. R. (1994). Educational research. Columbus, OH: Merrill.

Good, T. L. \& Brophy, J. E. (1990). Educational psychology: A realistic approach. New York: Longman.

Gordon, B. G., Stockard, J. W., \& Williford, H. (1992). The principal's role as school leader. Educational Research Quarterly, 15 (4), 29-38.

Greenberg, B. (1980). The Happy worker: Determinants of job satisfaction. American Journal of Sociology, 86, 247-271.

Greenlee, K. E. (1992). An analysis of leadership styles and job satisfaction in student affairs. Unpublished doctoral dissertation, Oklahoma State University.

Hack, W. G. (Ed.). (1971). Educational Administration. 2nd ed. Boston: Allyn and Bacon.

Halpin, A. W. (1966). How leaders behave: Theory and research in administration. New York: Macmillan.

Hanson, E. M. (1979). Educational administration and organizational behavior. Boston: Allyn and Bacon.

Hersey, P. \& Blanchard, K. H. (1977). Management of organizational behavior: Utilizing human resource. Englewood Cliffs, New Jersey: Prentice-Hall.

Hersey, P. \& Blanchard, K. H. (1988). Management of organizational behavior: Utilizing human resources (5th ed.). Englewood Cliffs, NJ: Prentice Hall.

Herzberg, F. (1966). Work and the nature of man. New York: World Publishing.

Ho, C. Z. (Ed.) (1981). Career Advisement and Dissertation Editing. Taipei: Da Yung Publishers. 
Hoppock, R. (1935). Job Satisfaction. New York: Harper. House, R. J. \& Mitchell, T. R. (1974). Path-goal theory of leadership. Journal of Contemporary Business, 3 , 81-98.

Hoy, W. K. \& Miskel, C. G. (1978). Educational administration: Theory, research, and practice. New York: Random House.

Hoy, W. K. \& Miskel, C. G. (1982). Educational administration: Theory, research, and practice (2nd. ed.). New York: Random House.

Hsu, S. C. (1991). Management (10th ed.). Taipei, Taiwan: Tung-Hua Books.

Huang, K. H. (1989). Educational administration. Taipei, Taiwan: Tung-Hua Books.

Hulin C. C. \& Blood, M.R. (1960). Job enlargement, individual differences, worker responses. Psychological Bulletin. 69 41-55.

Hung, C. S. (1979). The influence of job character on the job satisfaction of the education administration staff. Unpublished master's thesis, National Chiung Chie University.

Jacobs, M. J. (1993). Analysis of teacher perceptions related to change and change agents within a school-site setting. Unpublished doctoral dissertation, Florida International University, Miami.

Jorde, P. (1984). Teacher job satisfaction: A framework for analysis. Los Angeles: National Association for the Education of Young Children. (ERIC Document Reproduction Service No. ED 253 304)

Katz, J. (1982). A new academic disease: Faculty burnout. The Chronicle of Higher Education.

Keith, S. \& Girling, R. H. (1991). Education, management, and participation. Boston: Allyn and Bacon.

Kerlinger, F. N. (1973). Foundations of behavioral research (2nd ed.). New York: Holt, Rinehart, Winston.

Kim, N. I. (1986). The relationship between school principal leadership behavior and teacher stress, satisfaction, and performance in the schools of Incheon, Korea. Unpublished doctoral dissertation, University of Georgia. 
Klawitter, P. A. (1985). The relationship between principal's leadership style and teacher job satisfaction. Unpublished doctoral dissertation, West Virginia University, Virginia.

Konicek, D. G. (1992). Community college faculty who conduct industry training activities: A job satisfaction study. Community/Junior College Quarterly of Research and Practice, 16, (4), 361-372.

Landy, F. J. \& Trumbo, D. A. (1976). Psychology of work behavior. Homewood, IL: The Dorsey Press.

Leavitt, H. J. (1978). Managerial psychology (4th ed.). Taiwan: Taiwan Development Books.

Lin, C. M. (1992). Technical and vocational education development and perspective in Taiwan. Technical and Vocational Education Bimonthly, 9, 4-9.

Lin, H. F. (1983). A study of the relationship between principals' leadership style and teachers' job satisfaction in five-year junior colleges. Unpublished master's thesis, Taiwan Normal University, Taipei, Taiwan.

Lin, H. F. (1990). A study of the relationship between presidents' leadership style, organization atmosphere and organization performance in industry junior colleges in Taiwan. Unpublished doctoral dissertation, Taiwan Normal University, Taipei, Taiwan.

Lin, J. M. (1976). Hawthorne studies and influence--guide to the study of modern organization behavior. Taipei: Ta-i Books Store.

Lipham, J. M. (1968). Educational administration as a social process: Theory, research, practice. New York: Harper and Row.

Liu, L. H. (1986). The relationship between principals' leadership styles, sex, and school climate. Unpublished master's thesis. Taiwan Normal University, Taipei, Taiwan.

Mayo, E. (1933). The human problems of an industrial civilization. New York: Viking Press. 
McCormick, E. J. \& Tiffin, J. (1974). Industrial psychology. (6th ed.). Englewood Cliffs, NJ: Prentice-Hall.

McGregor, D. M. (1960). The human side of enterprise. New York: McGraw-Hill.

Mckee, J. G.(1991). Leadership style of community college presidents and faculty job satisfaction. Unpublished manuscript, Marshall University, Huntington, West Virginia.

Miller, W. \& Spark, D. (1984). Theory Z: The promise for U.S. schools. Educational Forum, $49,48-54$.

Miner, M. G. \& Miner, J. B. (1973). A guide to personnel management. Washington, D.C: The Bureau of National Affairs.

Miskel, C., DeFrain, J., \& Wilcox, K. (1980). A test of expectancy work motivation theory in educational organizations. Educational Administration Quarterly, 16 (1),70-92.

Neal, J. E. (1990, November). An examination of disciplinary differences in factors related to job satisfaction among liberal arts college faculty members. Paper presented at the annual meeting of the Association for the Study of Higher Education, Portland, OR.

Ouchi, W. (1981). Theory Z: How American business can meet the Japanese challenge. Boston: Addison-Wesley.

Owens, R. G. (1991). Organizational behavior in education (4th ed.). Boston: Allyn and Bacon.

Perkins, C. M. (1991). A study to investigate experienced teachers' job satisfaction and the teachers' perception of their principals' leadership styles. Dissertation Abstracts International. 52, 4171A.

Porter, L. W. (1961). A study of perceived need satisfactions in bottom and middle management jobs, Journal of Applied Psychology. 45, 1-10.

Porter, L. W. \& Lawler, E. E. (1968). Managerial attitudes and performance. Homewood, IL: Irwin. 
Reddin, W. J. (1970). Managerial effectiveness. New York: McGraw-Hill.

Redefer, F. L. (1959). Factors that affect teacher morale. The Nation's Schools, 63 , 59.

Savage, R. M. (1967). A study of teacher satisfaction and attitudes: Causes and effects. Unpublished doctoral dissertation, Aubum University.

Sashkin, M. (1987). A new vision of leadership. Journal of Management Development, $6(4), 19-28$.

Sashkin, M. 1988). Charismatic leadership. San Francisco: Jossey-Bass.

Sergiovanni, T. J. \& Carver, F. D. (1973). The new school executive: A theory of administration. New York: Dodd, Mead.

Smith, D. C. (Ed.). (1991). The Confucian continuum: Educational modernization in Taiwan. New York: Pacific Cultural Foundation.

Smith, P. C., Kendall, L. M., \& Hulin, C. L. (1969). The measurement of satisfaction in work and retirement. Chicago: Rand McNally.

Sonpon, T. N. (1984). An analysis of teachers' perceived sources of job satisfaction at the Monrovia Consolidated School System: A public school district in Liberia (Doctoral dissertation, University of California, Los Angeles, 1984). Dissertation Abstracts International, 44, 2948A.

Sorcinelli, M. D. \& Billings, D. A. (1992, April). The career development of pretenure faculty: An institutional study. Paper presented at the annual meeting of the American Educational Research Association, Atlanta, GA.

Stogdill, R. M. (1974). Handbook of leadership: A survey of theory and research. New York: Macmillan.

Strauss, G., Miles, R. E., Snow, C. C., \& Tannenbaum, A. S. (1976). Organizational behavior research and issues. Belmont, CA: Wadsworth.

Terry, G. R. (1960). Principles of Management 3rd ed.). Homewood, IL: Irwin. 
Tichy, N. M., \& Ulrich, D. D. (1984). The leadership challenge: A call for the transformational leader. Sloan Management Review, 26(1), 59-67.

Trice, H. M. \& Beyer, J. M. (1993). The cultures of work organizations. Englewood Cliffs, NJ: Prentice Hall.

Virtue, J. R. (1992). Causes of teacher turnover in church-related schools in the American Association of Christian Schools. Unpublished doctoral dissertation, Florida International University, Miami.

Vroom, V. H. (1964). Work and motivation. New York: Wiley.

Washington, R. and Watson, H. T. (1975). Positive teacher morale: The principal's responsibility. NASSP Bulletin, 60, 4-6.

Wexley, K. N. \& Yukl, C. A. (1978). Organizational behavior and personnel psychology. Taipei: Hua Tai Book Store.

White, R. and Lippitt, R. (1960). Autocracy and democracy: An experimental inquiry. New York: Harper \& Row.

Wickstrom, R A. (1971). An investigation into job satisfaction among teachers. Unpublished doctoral dissertation, University of Oregon.

World Journal.(Taiwan).( 1995, March 25). Al.

World Journal.(Taiwan).( 1995, June 8). Economy of Taiwan.

Wu, C. S. (1992). A study of school effectiveness. Taipei: Wunan Book Publishers.

Yukl, G. A. (1989). Leadership in organizations (2nd ed.). Englewood Cliffs, NJ: Prentice Hall.

Yung, K. (1985) Vocational Technical Education in Taiwan, Republic of China. Occupational Education Forum 14(1).

Zelazek, J. R. (1994). Teacher education follow-up study, 1994. (ERIC Document Reproduction Service No. ED 369 766) 
Zieng, M. Y. (1984). Administration staff management motivation in the middle school, the relationship of the internal and external locus of control, and job satisfaction. Unpublished master's thesis, National Chiung Chie University, Taipei, Taiwan. 
Appendix A

Letter of Permission from Vanderbilt University 
June 5,1995

Mr. Ching-San Chiang 9682 Fontainebleau Blvd \#405

Miami, FL 33128

Dear Mr. Chiang:

Thank you for your letter of May 30,1995. We understand that Homa Aminmadani has already sent you the Self and Other Leadership Orientations for you to gather your data and the Leadership Orientations Scores to help you analyze your data. We feel you would not get satisfaction from your research if you use self instrument alone. We feel in your study of The Effect of The Leadership Styles of the Taiwanese Junior College President on Teacher Job Satisfaction Self and Other would be more beneficial. You will have our permission to use our instruments if you use them in conjunction with each other and if your share your results with us.

In the meantime if you need any help feel free to contact us through Homa, and good luck with your studies.

Sincerely,

Tomu efminmadaxi for TED

Terrence E. Deal, Ph.D.

Professor of Education \&

Human Organizational Development
Aloma Efrimadanifor L.G.B.

Lee G. Bolman, Ph.D.

Chair, Block School of Business \&

Public A. - University of Missouri 
Appendix B

Leadership Orientations (Self) 
Form $\$ 3$

Your name:

\section{LEADERSHIP ORIENTATIONS (SELF)'} style.

This questionnaire asks you to describe your leadership and management

I. Behaviors

You are asked to indicate how often each of the items below is true of you.

Please use the following scale in answering each item.

$\begin{array}{lcccc}1 & 2 & 3 & 4 & 5 \\ \text { Never } & \text { Occasionally } & \text { Sometimes } & & \text { Often }\end{array}$

So, you would answer ' 1 ' for an item that is never true of you, ' 2 ' for one that is occasionally true, ' 3 ' for one that is sometimes true of you, and so on.

1. Think very clearly and logically.

2. Show high levels of support and concem for others.

3. Have exceptional ability to mobilize people and resources to get things done.

4. Inspire others to do their best.

5. Strongly emphasize careful planning and clear time lines.

6. Build trust through open and collaborative relationships.

7. Am a very skillful and shrewd negotiator.

8. Am highly charismatic.

9. Approach problems through logical analysis and careful thinking.

10. Show high sensitivity and concern for others' needs and feelings. 


\section{Leadership Orientations (Seif)}

11.

Am unusually persucsive and influential.

12. Am able to be an inspiration to others.

13. Develop and implement clear, logical policies and procedures.

14. Foster high levels of participation and involvement in decisions.

15. Anticipate and deal adroitly with onganizarional conflict.

16. Am highty imaginative and creative.

17. Approach problems with facts and logic.

18. Am consistently helpful and responsive to others.

19. Am very effective in getting support from people with influence and power.

20. Communicate a strong and challenging sense of vision and mission.

21. Set specific, measurable goals and hold people accountable for results.

22. Listen well and am unusually receptive to other people's ideas and input.

23. Am politically very sensitive and skillful

24. See beyond curtent realities to generate exciting new opportunities.

25. Have extraordinary attention to detait

26. Give personal recognition for work well done.

27. Develop alliances to build a strong base of support.

28. Generate loyalty and enthusiasm.

29. Strongly believe in clear structure and a chain of command.

30. Am a highly participative manager.

31. Succeed in the face of conflict and opposition.

32. Serve as an influential model of organizational aspirations and values. 


\section{Leadership Style}

This section asks you to describe your leadership style. For each item, give the number " 4 " to the phrase that best describes you, " 3 " to the item that is next best, and on down to " 1 " for the item that is least like you.

1. My strongest skills are:
a. Anatytic skills
b. Interpersonal skills
c. Political skills
d. Ability to excite and motivate

2. The best way to describe me is:
a. Technical expert
b. Good listener
c. Skilled negotiator
d. Inspirational leader

3. What has helped me the most to be successful is my ability to:

a. Make good decisions

b. Coach and develop people

c. Build strong alliances and a power base

d. Energize and inspire others

4. What people are most likely to notice about me is my:

a. Attention to detail

b. Concem for people

c. Ability to succeed, in the face of conflict and opposition

d. Charisma

5. My most important leadership trait is:

\section{a. Clear, logical thinking}

b. Caring and support for others

c. Toughness and aggressiveness

d. Imagination and creativity 
Leadership Orientations (Seif)

6. I am best described as:
a. An anatyst
b. A humanist
c. A politician
d. A visionary

III. Overall rating

Compared to other individuals that you have known with comparable levels of experience and responsibility, how would you rate yourself on:

1. Overall effectiveness as a manager.

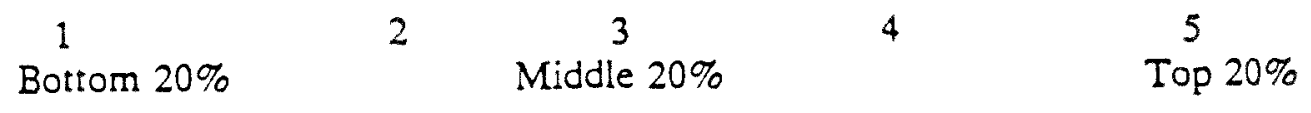

2. Overall effectiveness as a leader.

$\begin{array}{llccc}1 & 2 & 3 & 5 \\ \text { Bottom } 20 \% & & \text { Middle 20\% } & & \text { Top 20\% }\end{array}$


Appendix C

Leadership Orientations (Other) 
Name of person described:

\section{LEADERSHIP ORIENTATIONS (OTHER) ${ }^{1}$}

This questionnaire asks you to describe the person that you are rating in terms of leadership and management style.

\section{Leader Behaviors}

You are asked to indicate how ofien each item is true of the person that you are rating.

Please use the following scale in answering each item.

$\begin{array}{ccccc}1 & 2 & 3 & 4 & 5 \\ \text { Never } & \text { Occasionally } & \text { Sometimes } & \text { Often } & \text { Always }\end{array}$

So, you would answer ' 1 ' for an item that is never true of the person you are describing, ' 2 ' for one that is occasionally true, ' 3 ' for one that is sometimes true, and so on.

1. Thinks very clearty and logically.

2.

Shows high levels of support and concem for others.

3.

Shows exceprional ability to mobilize people and resources to get things done

4. Inspires others to do their best.

5. Strongty emphasizes careful planning and clear time lines.

6. Builds trust through open and collaborative relationships.

7.

Is a very skillful and shrewd negoriator.

8.

Is highly charismatic.

9. Approaches problems through logical analysis and careful thinking.

10. Shows high sensitivity and concern for others" needs and feelings.

11. Is unusualty persuasive and infuential

12. Is an inspiration to others.

1. 1990, Leadership Frameworks. 
13.

14.

15.

16.

17.

18.

19.

20.

21.

22

23.

24.

25.

26.

27.

28.

29.

30.

31.

32.
Develops and implements clear, logical policies and procedures.

Fosters high levels of participarion and involvement in decisions.

Anticipates and deals adroitly with onganizarional conflict.

Is highty imaginative and creative.

Approaches problems with facts and logic.

Is consistently helpful and responsive to others.

Is very effective in getring suppor from people with influence and power.

Communicates a strong and challenging vision and sense of mission

Sets specific, measurable goals and holds people accountable for results.

Listens well and is unusually receptive to other people's ideas and input.

Is politically very sensitive and skillful

Sees beyond current realities to create exciting new opportunities.

Has atraordinary attention to detail

Gives personal recognition for work well done.

Develops alliances to build a strong base of support.

Generates loyaly and enthusiasm

Strongty believes in clear structure and a chain of command.

Is a highty participative manager.

Succeeds in the face of conflict and opposition.

Serves as an infuertial model of organizational aspirations and values. 


\section{Leadership Style}

This section asks you to describe the leadership style of the person that you are rating. For each item, give the number " 4 " to the phrase that best describes this person, " 3 " to the item that is next best, and on down to " 1 " for the item that is least like this person.

1. The individual's strongest skills are:

\begin{tabular}{ll} 
a. & Anatytic skills \\
\hline b. & Interpersonal skills \\
c. & Political skills \\
d. & Ability to acite and motivate
\end{tabular}

2. The best way to describe this person is:

\begin{tabular}{ll} 
a. & Technical expen \\
\hline b. & Good listener \\
c. & Skilled negotiator \\
d. & Inspirational leader
\end{tabular}

3. What this individual does best is:

$\begin{array}{ll}\text { a. } & \text { Make good decisions } \\ \text { b. } & \text { Coach and develop people } \\ \text { c. } & \text { Build strong alliances and a power base } \\ \text { d. } & \text { Energize and inspire others }\end{array}$

4. What people are most likely to notice about this person is:

$\begin{array}{ll}\text { a. } & \text { Attention to detail } \\ \text { b. } & \text { Concem for people } \\ \text { c. Ability to succeed in the face of conflict and opposition } \\ \text { d. }\end{array}$

5. This individual's most important leadership trait is:

$\begin{array}{ll}\text { a. } & \text { Clear, logical thinking } \\ \text { b. } & \text { Caring and support for others } \\ \text { c. } & \text { Toughness and aggressiveness } \\ \text { d. } & \text { Imaginarion and crearivity }\end{array}$

6. This person is best described as:

$\begin{array}{ll}\text { a. } & \text { An analyst } \\ \text { b. } & \text { A humanist } \\ \text { c. A politician } \\ \text { a. } & \text { A visionary }\end{array}$




\section{Overall ratiog}

Compared to other individuals that you have known with comparable levels of experience and responsibility, how would you rate this person on:

1. Overall effectiveness as a manager.

1

Bottom 20\%

2. Overall effectiveness as a leader.

1

Bottom 20\%

\section{2}

2

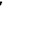

3

Middle $20 \%$
4 5

Top 20\%

\section{Optional Demographic Information}

The following information is not required, and will not be provided to the ratee, but will contribute to our efforts to understand how perceptions of leadership styles are influenced by the relationship between rater and ratee.

1. Are you: Male Female

2. How many years have you been associated with this principal?

3. Please check the option below that best describes your work relationship to the principal that you are describing.
A. Central office

I am the superintendent.

I I am an administrator in the central office

I I am a member of the central office support staff.

B. Same School as Principal

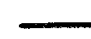
I am a teacher or other professional staff member in this principal's school.
I I am an administrator in this principal's school.
I I am a student in this principal's school.
I I am a member of the support staff in this principal's school. 
Leadership Orientations (Other)

C. Community

_ I am a parent.

_ I am a board member.

I I am a community member.

__ I am a city/town official. Please specify:

D. Different School

I I am a principal in another school.

_ I am a staff member in another school.

E Other: please specify: 


\section{Appendix D}

The Job Descriptive Index 


\title{
...... \\ JOB \\ DESCRIPTIVE \\ INDEX
}

(RI:VISI:I)

$\overline{1}$

\author{
Company \\ viliy
}

Please fill in lice uluove

Blants unil liecil urm the

puge....

Code No. 


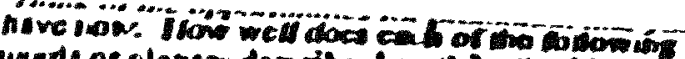

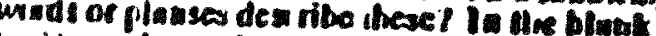
besidt cixth worle or pherisse beting, wrille

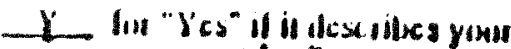

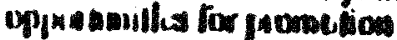

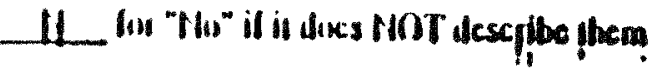

1 if you canum ilecide

\section{OPPOATINITIES FOA PROMGITION}

Ciond ofycortuilics for promatua

Oygnatunisics sinucwhat limiled

Promolion on abilisy

Ixal enel juls

Gimal clance for promalion

$\vec{N}$

Ilinfair promusion policy

IIficjuxul promouious

Hegular purounowions

fiaily gomul cliance for promation

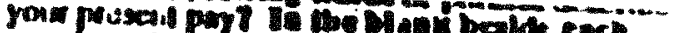

woril os phicel loctom, mile

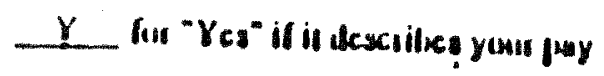

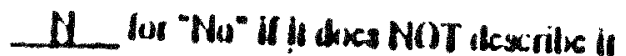

1. Il you canos decide

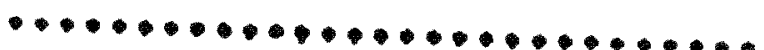

\section{PRESant Par}

Income sulequale fix mormal capenses Fuis

Itascly live on income

IIuI

lixume provhica lusurices

linsciure

I css ihan I deserve

Well pill

Underpain

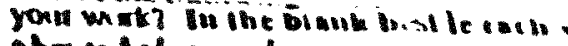
phrusetelin, malie

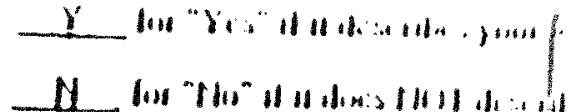

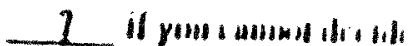

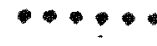

IVIIIK IN IUIISSIENI JUI! Fiacinaning

Mn+1!n!

Satislyomb

_Handirs

Lienel

Cicmive:

_L_toskathl

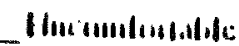

I'Hads.III

Ilsctul|

Inings

Ilcallhtul

Chillingsous

Inu much lud

Iando.tumb

Simpla:

llepenine

Cives sease ol ancomplobluncul 


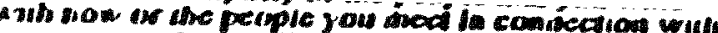
mint wink. Hon well iries cach of due following

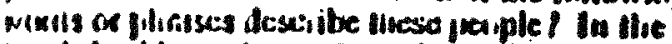
blink tu thle ear a word in phinse belinw. wille

Y for "Yes" If it describes the jucoule yinuch wiln

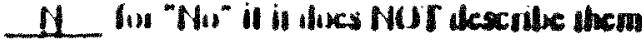
T. il you calum ulccidc

\section{(I).W(HIK IEIS (PEOTLE)}

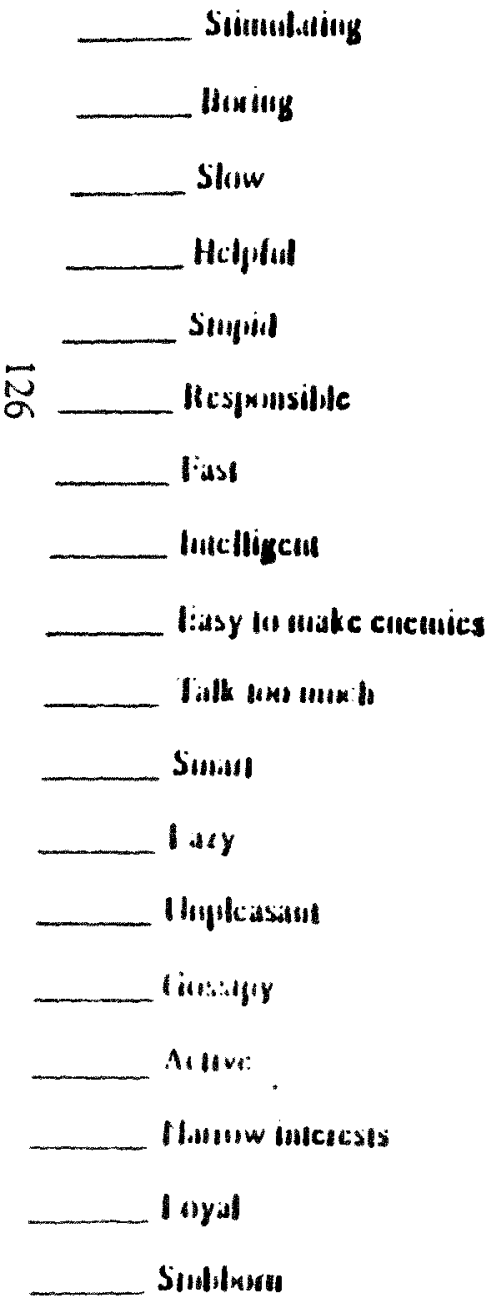

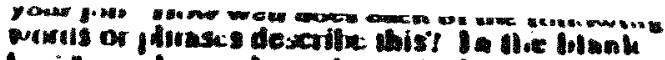
beside cull word or phrase be hne, w fle

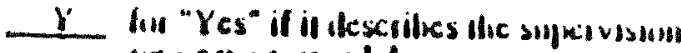
you get oa you bo

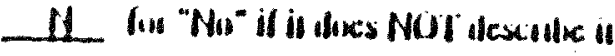

I if yun cammu ulciulc

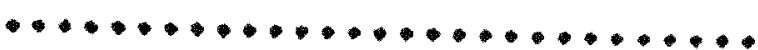

SIIPlit VISIIIN

Asls my alvice

H.11I III plliast:

IIIjnalie

lialises gind wort

Tin tul

Iulliculial

U1 w dale

Ihxish I suntivise cambl

Has lavenifes

Iills anc where | reaul

Anungiuns

Sinilunan

Kanws jub well

and

IiIl: lligcus

linu platuica

Alimal whe bectal

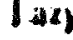

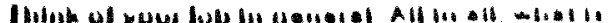

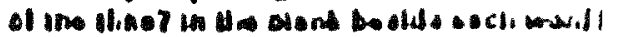

Y tas "Yee" 1111 Hescilles yourjob

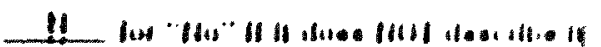

1 II yous cousmil alodile

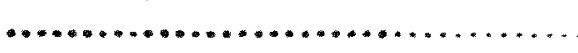

HOE IN OENEMAL

H'tesenou!

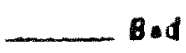

|110.81

Wento wlllwe

Gous

indeatialise

Wulliwlille

Woted fletr atwel

- Accopilatilo

Singendun

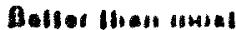

Diseureeslile

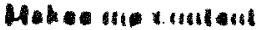

Luentoguele

Exallon!

mullen

loperyolis.

Pros 


\section{Appendix $\mathrm{E}$}

President's Leadership Orientations

(Presidents' Questionnaire) 


\section{PRESIDENTS LEADERSHIP ORIENTATIONS \\ ( PRESIDENTS' QUESTIONNAIRE)}

Dear President:

The purpose of this questionnaire is to collect data that will be used in a doctoral dissertation. The study investigates the relationship between teachers' perceptions of junior college presidents' leadership orientation and teacher job satisfaction.

This survey is anonymous and confidential. Based on your personal teaching experience, please complete all of the questions. Please do not leave any question unanswered. Your opinions are very vahuable to this research. Thank you for your help and support in this important endeavor.

Best Regards,

Ching-San Chiang

Department of Educational Leadership and Policy Studies College of Education Florida Intemational University 
This Questionnaire is divided into two parts. The first part (4 items) collects

demographic data; the second part (44 items) collects information about the leadership orientations of college presidents.

\section{Demographic Data (Items 1-4)}

Instructions: Please select the number that represents the best answer for each item. Then write the number in the blank.

1._._Age

(1) 44 years old or younger

(2) 45 years old or olderi

2. How long have you been the president of this college?

(1) 1 to 6 years (including this year)

(2) 7 years or more

3. School status

(1) public college

(2) private college

4. School size of your service:

(1) under 3000 studentsi

(2) $3000-5000$ studentsì

(3) over 5000 students 


\section{Leadership Orientations}

Instructions: Please describe your leadership and management style. Select the number that represents the best response for each item.

\section{Leader Behavior (5-36)}

Using the scale from 1 (never) to 5 (always), please indicate how often each of the items below is true of you.

1 (Never) 2 (Occasionally) 3 (Sometimes) 4 (Often) 5 (Always)

Explanation: Write ' 1 ' for an item that is never true, ' 2 ' for one that is occasionally true,

' 3 ' for one that is sometimes true, and so on.

5. I think very clearly and logically.

6. I show high levels of support and concern for others.

7. I have exceptional ability to mobilize people and resources to get things done.

8. I inspire others to do their best.

9. I strongly emphasize careful planning and clear time lines.

10. I I build trust through open and collaborative relationships.

11. I Im a very skillful and shrewd negotiator.

12. I I am highly charismatic.

13. I approach problems through logical analysis and careful thinking.

14. I show high sensitivity and concern for others' needs and feelings.

15. I am usually persuasive and influential. 
16. I am able to be an inspiration to others.

17. I develop and implement clear, logical policies and procedures.

18. I foster high levels of participation and involvement in decisions.

19. I anticipate and deal adroitly with organizational conflict.

20. I am highly imaginative and creative.

21. I approach problems with facts and logic.

22 I I am consistently belpful and responsive to others.

23. I am very effective in getting support from people with influence and power.

24. I communicate a strong and challenging sense of vision and mission.

25. I set specific, measurable goals and hold people accountable for results.

26. I I listen well and am unusually receptive to other people's ideas and input.

27. I I am politically very sensitive and skillful.

28. I see beyond current realities to generate exciting new opportunities.

29. I L have extraordinary attention to detail.

30. I give personal recognition for work well done.

31. I develop alliances to build a strong base of support.

32. I generate loyalty and enthusiasm.

33. I strongly believe in clear structure and a chain of command.

34. I am a highly participative manager.

35. I succeed in the face of conflict and opposition.

36. I serve as an influential model of organizational aspirations and values. 
Please describe your leadership style. For each item, write the number ' 4 ' in the blank next to the phrase that best describes you, ' 3 ' next to the phrase that is next best, and on down to ' $l$ ' for the phrase that least describes you.

37. My strongest skills are;

a.Analytic skills

b. Interpersonal skills

c.Political skills

d.Ability to excite and motivate

38. The best way to describe me is:

a. Technical expert

b. Good listener

c. Skilled negotiator

d.Inspirational leader

39. What has helped me the most to be successful is my ability to:

a.Make good decisions

b. Coach and develop people

c.Build strong alliances and a power base

d. Energize and inspire others

40. What people are most likely to notice about me is:

a.Attention to detail

b. Concern for people

c.Ability to succeed, in the face of conflict and opposition

d.Charisma

41. My most important leadership trait is:
a. Clear, logical thinking
b. Caring and support for others
c. Toughness and aggressiveness
d. Imagination and creativity 
42. I am best described as:

a.An analyst

b.A humanist

c.A politician

d. A visionary

III. Overall rating (43-44)

Please circle the number that best rates you.

Compared to other individuals you have known withcomparable levels of experience and responsibility, how would you rate yourself on:

43. Overall effectiveness as a manager.

$\begin{array}{ccccc}1 & 2 & 3 & 4 & 5 \\ \text { Bottom 20\% } & & \text { Middle } 20 \% & & \text { Top } 20 \%\end{array}$

44. Overall effectiveness as a leader.

$\begin{array}{ccccc}1 & 2 & 3 & 4 & 5 \\ \text { Bottom 20\% } & & \text { Middle 20\% } & & \text { Top 20\% }\end{array}$

Thank you for your support and cooperation. 
Appendix F

President's Leadership Orientations and

Teacher Job Satisfaction

(Teachers' Questionnaire) 


\section{PRESIDENTS' LEADERSHIP ORIENTATIONS AND \\ TEACHER JOB SATISFACTION \\ (TEACHERS' QUESTIONNAIRE)}

Dear Teacher:

The purpose of this questionnaire is to collect data that will be used in a doctoral dissertation. The study investigates the relationship between teachers' perceptions of junior college presidents' leadership orientations and teacher job satisfaction.

This survey is anonymous and confidential. Based on your personal teaching experience, please answer all of the questions. Your opinions are very valuable to this research. Thank you for your help and support in this important endeavor.

Best Regards,

\section{Ching-San Chiang}

Department of Educational Leadership and Policy Studies College of Education Florida International University 
This Questionnaire is divided into three parts. The first part (items 1-8) collects demographic data; the second part (items 9-49) collects information about your present job satisfaction (9-49); the third part (items 50-89) solicits your opinions about the leadership orientation of the president of your college.

\section{Demographic Data (Items 1-8)}

Instructions: Please select the number that represents the best answer for each item. Write the number in the blank.

1. Sex
(1) Male
(2) Female

2. Age
(1) 29 years old or less
(2) 30 to 39 years old
(3) 40 to 49 years old
(4) 50 to 59 years old
(5) 60 years old or older

3. Length of Service (including this year):
(1) 1 - 3 years
(2) $4-10$ years
(3) $11-15$ years
(4) 16 - 20 years
(5) 21 years or more

4. Educational Level
(1) Doctorate
(2) Masters
(3) Bachelors
(4) Junior College Graduate
(5) Other (Please explain) 
5. _ Academic rank

(1) Professor

(2) Associate Professor

(3) Assistant Professor

(4) Instructor

(5) Assistant

6. Do you hold an administrative task?

(1) Yes

(2) No

7.__ School status

(1) Public college

(2) Private college

8. School size
(1) under 3000 students
(2) 3000 - 5000 students
(3) over 5000 students

II. Job Satisfaction Questionnaire (Items 9-49)

Using the scale below, please indicate the extent to which you are satisfied with the situation described in each of the following statements.

$5=$ Very Satisfied, $4=$ Satisfied, $3=$ Neither satisfied nor dissatisfied, 2 = Dissatisfied, $1=$ Very Dissatisfied.

Instructions: Please select the number that represents the best response to each item Then write the number in the blank.

9.__ Opportunity to display individual specialty.

10. Opportunity to get together with students.

11. Opportunity to freely evahuate your work.

12. Opportunity for promotion and development in present job

13. Teachers' salary as compared to salaries of other professions 
14. Opportunity to develop individual ideal and ambition.

15. The volume of teaching load.

16. The president's requirements on the teacher's job.

17._Ability to learn and enrich yourself through teaching.

18. Teachers' salary as compared to work load

19. Opportunity for change and creativity.

20. The support of colleagues.

21._President's understanding of subordinate's efforts.

22 Opportunity to try new teaching methods.

23. Job secury and protection

24.___ Feeling of job-related achievement.

25. Availability of appropriate and adequate materials, tools, and equipment

26. Opportunity to communicate with the president.

27. Teacher reward system

28. Being respected in your community and neighborhood.

29._Individual work performance.

30. Performance and promotion competition among colleagues

31. President's ability to help teachers solve problems

32. Promotion opportunities.

33. Varied welfare measures provided by school

34._Experiencing challenging work. 
35. Traditional school customs.

36. The president's method of handling disagreements between colleagues.

37. Opportunities for increased rewards.

38. Individual rewards obtained for teaching.

39. Growth in both teaching and learning to help individual progress.

40. Cooperative team spirit among colleagues.

41.__ Principal's leading and decision-making ability.

42. The way teachers are recognized for excellent performance.

43. Confirmation to individual social status.

44. Opportunity to serve society and benefit people.

45. The school building.

46. Opportunity for teachers' attending to prepare the administration plan of school.

47. School provides the opportunity for teachers' advance study.

48. The level of acceptance of me by the student,s parents.

49. The presidents' attitude toward teachers. 


\section{President's Leadership Orientations Questionnaire}

Please describe the college president you are rating in terms of leadership and management style.

I. Leader Behaviors (Items 50-89)

Instructions: Please use the following rating scale to indicate how often each item is true of the president of you college.

$\begin{array}{ccccc}1 & 2 & 3 & 4 & 5 \\ \text { Never } & \text { Occasionally } & \text { Sometimes } & \text { Often } & \text { Always }\end{array}$

Select the number that represents the best response for each item. Then write that number in the blank.

For example, write ' 1 ' for an item that is never true of the president, ' 2 ' for one that is occasionally true, ' 3 ' for one that is sometimes true, and so on.

50. Thinks very clearly and logically.

51. Shows high levels of support and concem for others.

52. Shows exceptional ability to mobilize people and resources to get things done.

53. Inspires others to do their best.

54. Strongly emphasizes careful planning and clear time lines.

55. Builds trust through open and collaborative relationships.

56. Is a very skillful and shrewd negotiator.

57.__ Is highly charismatic.

58. Approaches problems through logical analysis and careful thinking.

59. Shows high sensitivity and concern for others' needs and feelings.

60. Is usually persuasive and influential.

61. Is an inspiration to others. 

Develops and implements clear, logical policies and procedures.

63. Fosters high levels of participation and involvement in decisions.

64. Anticipates and deals adroitly with organizational conflict.

65. Is highly imaginative and creative.

66. Approaches problems with facts and logic.

67. Is consistently helpful and responsive to others.

68. Is very effective in getting support from people with influence and power.

69. Communicate a strong and challenging vision and sense of mission.

70._ Sets specific, measurable goals and holds people accountable for results.

71. Listens well and is unusually receptive to other people's ideas and input.

72. Is politically very sensitive and skillful.

73. Sees beyond current realities to create exciting new opportunities.

74. Has extraordinary attention to detail.

75. Gives personal recognition for work well done.

76. Develops alliances to build a strong base of support.

77.__ Generates loyalty and enthusiasm.

78. Strongly believes in clear structure and a chain of command.

79. Is a highly participative manager.

80. Succeeds in the face of conflict and opposition.

81. Serves as an influential model of organizational aspirations and values. 
Please describe the leadership style of the person you are rating. For each item, write ' 4 ' for the phrase that best describes the president, ' 3 ' for the phrase that is next best, and on down to ' 1 ' for the phrase that least describes the president of your college. Write the number in the blank.

82. The individual's strongest skills are:

a. Analytic skills

b. Interpersonal skills

c. Political skills

d. Ability to excite and motivate

83. The best way to describe this person is:
a. Technical expert
b. Good listener
c. Skilled negotiator
d. Inspirational leader

84. What this individual does best is:

a. Make good decisions

b. Coach and develop people

c. Build strong alliances and a power base

d. Energize and inspire others

85. What people are most likely to notice about this person is:

a. Attention to detail

b. Concern for people

c. Ability to succeed, in the face of conflict and opposition

d. Charisma

86. This individual's most important leadership trait is:

a. Clear, logical thinking

b. Caring and support for others

c. Toughness and aggressiveness

d. Imagination and creativity 
87. This person is best described as:

a. An analyst

b. A humanist

c. A politician

d. A visionary

III. Overall rating (88-89)

Instructions: Circle the number that best rates the person you are rating.

Compared to other individuals that you have known with comparable levels of experience and responsibility, how would you rate the president of your college on:

88. Overall effectiveness as a manager.

$\begin{array}{ccccc}1 & 2 & 3 & 4 & 5 \\ \text { Bottom } 20 \% & & \text { Middle } 20 \% & & \text { Top 20\% }\end{array}$

89. Overall effectiveness as a leader.

$\begin{array}{ccccc}1 & 2 & 3 & 4 & 5 \\ \text { Bottom } 20 \% & & \text { Middle } 20 \% & & \text { Top 20\% }\end{array}$

Thank you for your support and cooperation. 
Appendix G

Letter of Verification 
This is to verify that the Chinese versions of the two questionnaires in Chiang, Ching-San's dissertation, The Effects of the Leadership Styles of the Taiwanese Junior College Presidents on Teacher Job Satisfaction, are correctly translated from the original English versions. The titles of the questionnaires are Teacher Job Satisfaction Questionnaire and Leadership Qrientations Questionnaire.

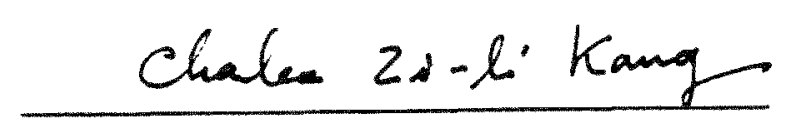

Kang, Zi-Li

Professor, Graduate School of Industrial Vocational Education National Chang-hua University of Education 
Appendix $\mathrm{H}$

President's Leadership Orientations

(Presidents' Questionnaire)

(Chinese Versions) 


\section{領導導向調查問卷}

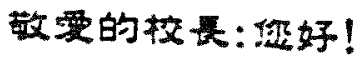

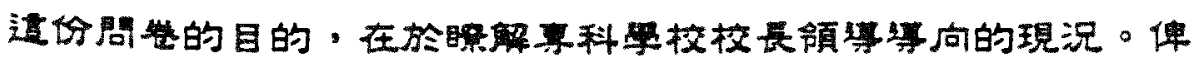

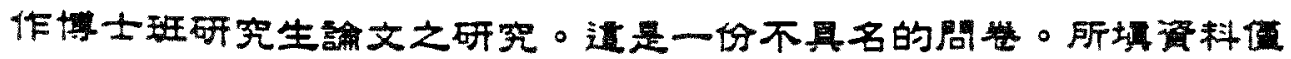

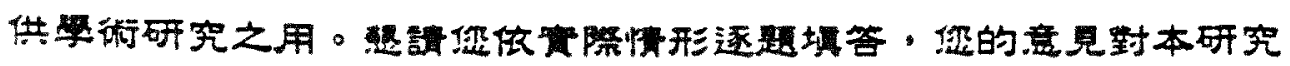

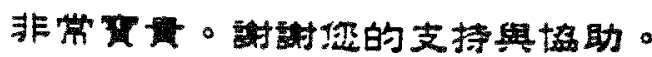

敬祝教安

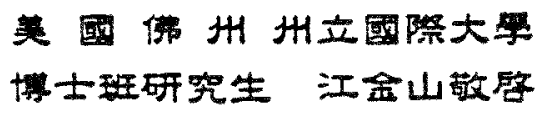

填答說明

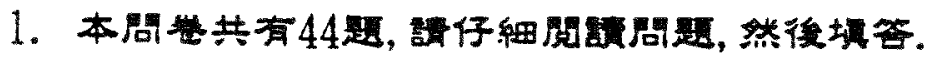

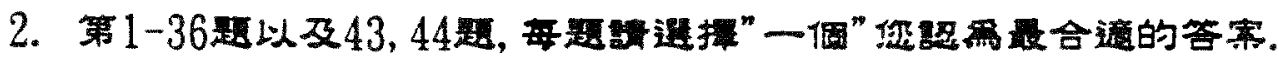

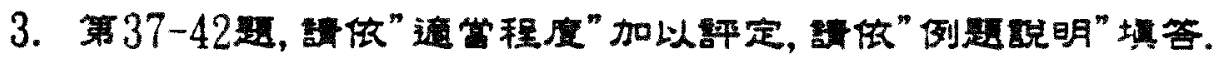

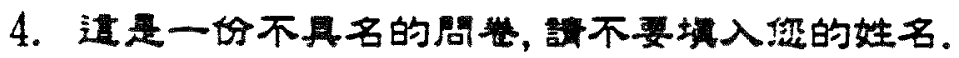

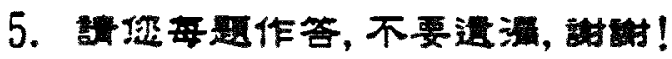

\section{第1-4題基本資料}

1. 年齢
(1) 44 以下
(2) 45 影上上

2.

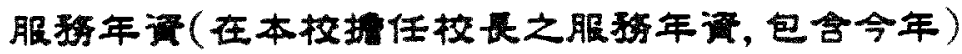
(1) 6 年 (合) 以下
(2) 7 年以上

3.

悬挍性面:
(1) 公立舆校
(2) 私立學校

4.

學校规掼

(1) 30001固學生及以下

(2) 3001-5000個学生

（3）5001䧃学生及以上 
32.

引發忠諴度及繁心。

33.

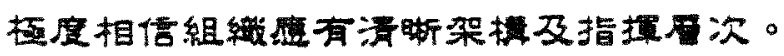

34. 保一個具豆度舆盛的經理人。

35. 成功地面對面突及反跱。

36.

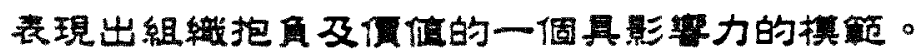

第37-42題請您描述您的領導型態。每個項目給” 4" 表示對您自己的 最佳描述，"3"是次佳，遞減至"1"表示最不符合這個人。

椡题玟明

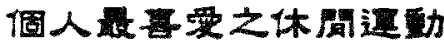

$\begin{array}{cc}\text { a. } & \text { 打球 } \\ \text { b. } & \text { 还山 } \\ \text { c. } & \text { 游泳 } \\ \text { d. } & \text { 跑跑 }\end{array}$

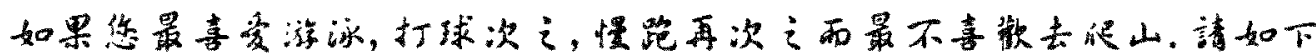
填答。

\begin{tabular}{lll}
$\frac{3}{1}$ a. & 打球 \\
\hline$\frac{4}{2}$ c. 涎山 \\
\hline
\end{tabular}

37. 個人最嬏的能力是 :
— a. 分析能力
b. 人際臹係的能力
— c. 政治能力
- d. 勫動及漖勘的能力

38. 我固人的最佳描述是：

a. 技街悬家

b. 好的便洫者

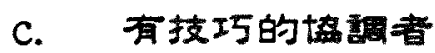

d. 辟呅型的領繁者 
第5-36題是請您描迅評估您自己的領導及管理型態。

請您語估自己對以下每一項目的程度。

請用以下的分數回答每個項目。

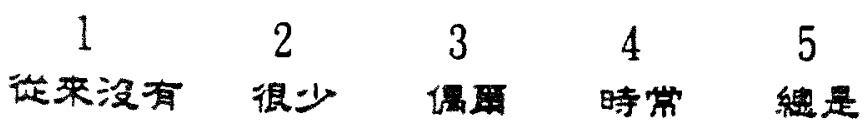

所以, 如果您在某個項目回答” 1 ", 即您所描迅的人不是如此, "2” 表示很少如此, "3"表示偶爾如此, 其餘数推。

5.

6.

7.

8.

9.

10.

11.

12.

13.

14.

15.

16.

17.

18.

19.

20.

21.

22.

23.

24.

25.

26.

27.

28.

29.

30.

31.

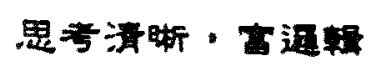

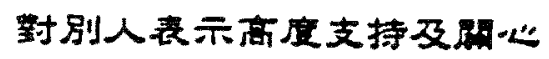

顆示非凡能力動员人手及诲源宽成任特。

激趿別人萧力。

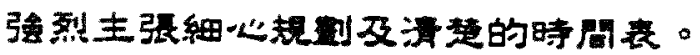

透兑用放及合作的的係建立估任。

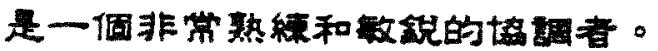

有落度的领紫能力。

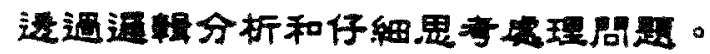

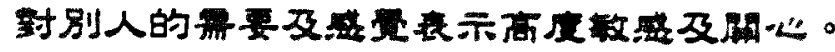

經常畹服及影管他人。

能管铰別人。

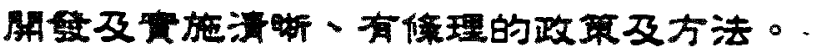

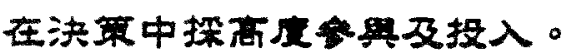

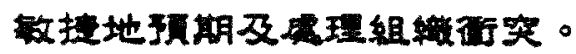

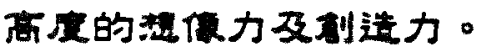

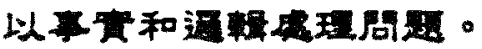

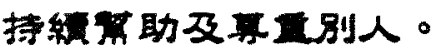

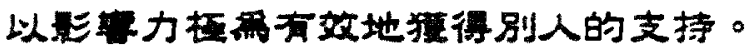

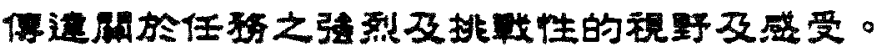

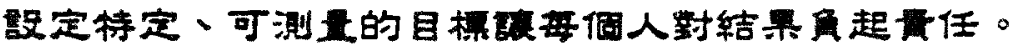

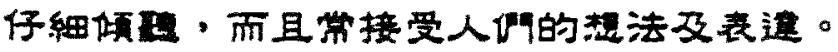

在政治方面非常敬盛及熟縞。

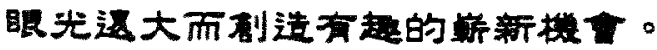

非常注意細第。

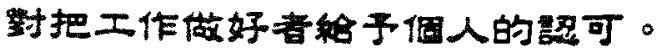

解同盟者以建立强有力的支持基整。 
39. 個人的最佳成就是：

— a. 敏好的決定

一. 訓練及培费人才

- c. 建立有力的同盟及撞力基磄

一 d. 篹起及激趿别人

40. 我給別人的大多数印承是:

- a. 注番細節

b. 䟝人

- c. 成功面璟衙突和敨璟的能力

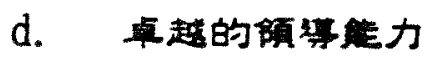

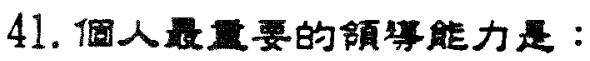

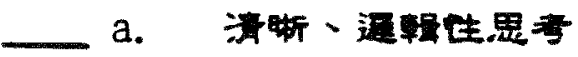

一 b. 成边及支持别人

- c. 照定及樌柾

d. 湿信力及剽造力

42. 個人的最佳描进是：

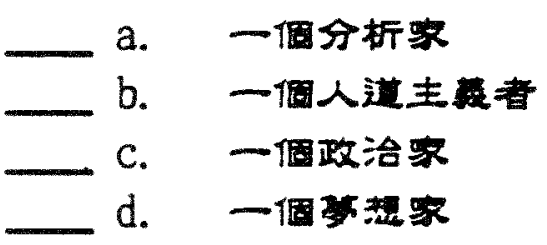

第43-44題是請您以整體表現(經驗和責任等)可比較的程度, 特您與 您所知的別人比較, 您對自己的評估是：

43.

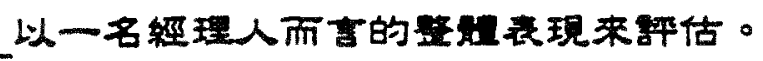

$\begin{array}{lllll}1 & 2 & 3 & 4 & 5 \\ \text { 中 } & & & \text { 高 }\end{array}$

44.

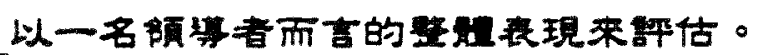
1

$\begin{array}{llll}2 & 3 & 4 & 5 \\ & \text { 中 } & & \text { 高 }\end{array}$

低

中

高

*** 謝謝您的赛貴意見 *** 


\section{Appendix I}

President's Leadership Orientations and Teacher Job Satisfaction

(Teachers' Questionnaire)

(Chinese Versions) 


\section{專科學校校長與老師互動關係調查問卷}

敬爱的老師：䐎好!

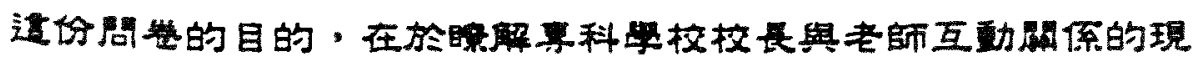

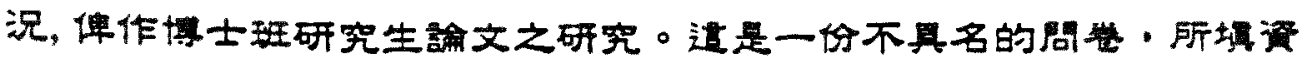

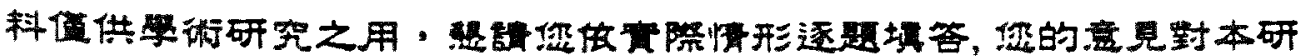

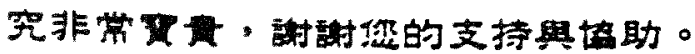

敬祝教安

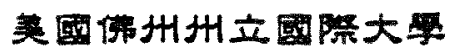

博士研究生 江金山 敬㹂

填答說明

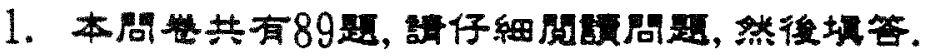

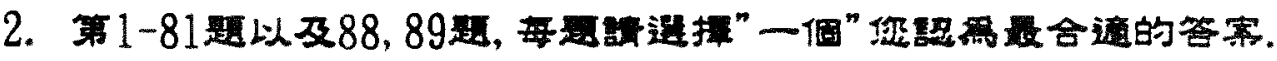

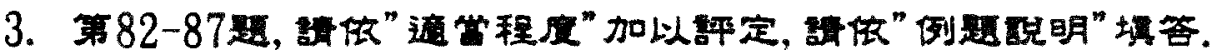

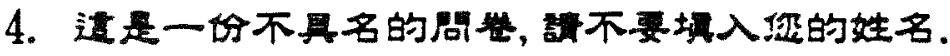

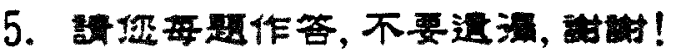

1.

性別

(1) 男性

(2) 女性

2.

年龄

(1) 29 耤及以下

(2) $30-39$ 站

(3) 40-49

(4) $50-59$ 赔

(5) 60 政及以上

3.

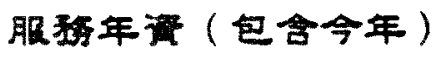

(1) 1 - 3年

(2) 4-10年

(3) 11-15年

(4) 15-20年

(5) 21 年及以上 
4.

等晨 (1) 博士

(2) 碽士

(3) 量士

(4) 具科显棠

（5）其他（铸镍明）

5.

獞級 (1) 数授

(2) 副教授

(3) 助理数授

(4) 敦師

(5) 助数

6.

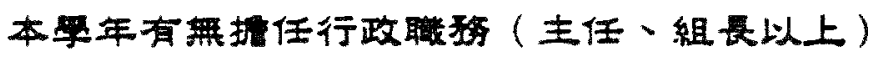
(1) 有
(2) 無

7. 孚校性盆

(1) 公立學校

(2) 私立基校

8. 學校规模
(1) 3000 個學生及以下
(2) 3001-5000個悬生
（3）5001個拲生及以上

第9-49題, 請根據您目前的工作情形, 表達您對每一項目的滿意程 度, 並請用以下的分數回答每個項目。

$$
\begin{aligned}
& 5=\text { 很洋尞 } \\
& 4=\text { 洲責 } \\
& 3=\text { 無意胃 } \\
& 2=\text { 不苏意 } \\
& 1 \text { = 很不苏意 }
\end{aligned}
$$

9.

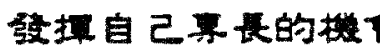

10.

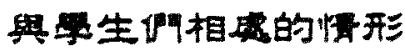


11. 在工作中能自由故制断的機合

12.

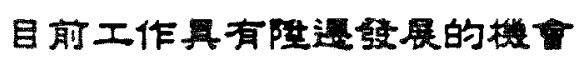

13. 教師的畭纾與其他行蓝相比

14. 有展現自己理规舆抱角的譏會

15.

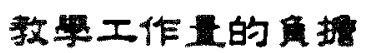

16. 校長璟教師工作的要求

17.

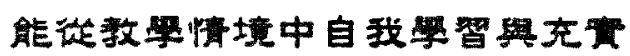

18.

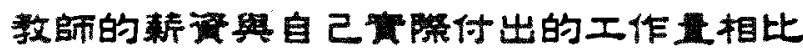

19. 工作中有繁剽新的機

20. 校内同票璟我工作上支持的惯形

21.

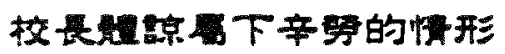

22.

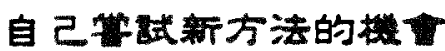

23.

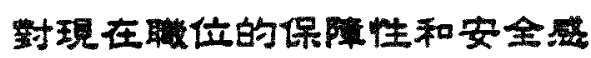

24. 徒工作中所讙得的成就盛

25. 工作上所黑铰㙌的提供情形

26.

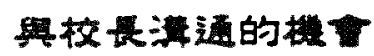

27.

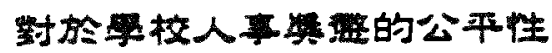

28.

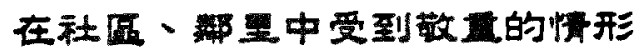

29. 璟自己的工作成果

30.

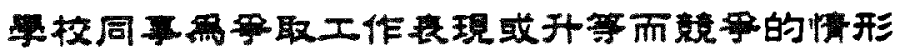

31.

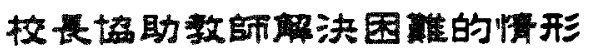

32.

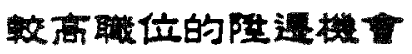

33.

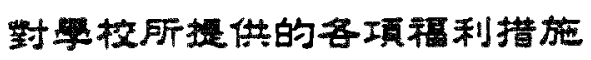


34.

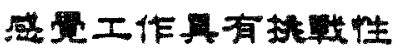

35.

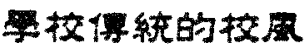

36.

37.

38.

39.

40.

41.

42.

43.

44.

45.

46.

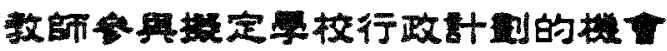

47.

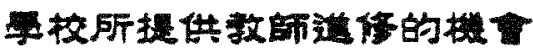

48.

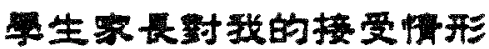

49. 挍長璟数師的照度

第50-89題請您描迅一個您以領㜕能力及管理型態加以評分的人(貴 校校長)。

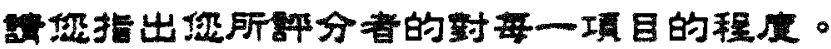

到用以下的分数回答再個项目。

\begin{tabular}{|c|c|c|c|}
\hline 1 & 2 & 3 & 4 \\
\hline E来没有 & 很少 & 谓两 & 時常 \\
\hline
\end{tabular}


所以, 如果您在某個項目回答 $1^{n}$, 即您所描述的人不是如此, "2" 表示很少如此, "3" 表示偶爾如此, 其餘類推。

50.

51.

思考淇晰，冝逼轱

52.

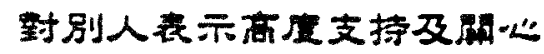

53.

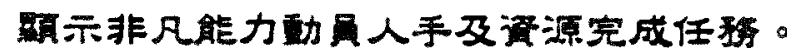

54. 做趿別人曩力。

55.

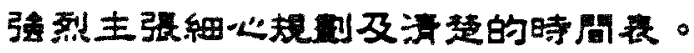

56.

57.

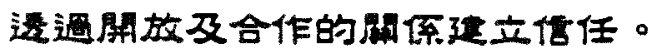

58.

59.

60.

61.

62.

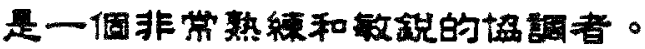
有离度的领第能力。

63.

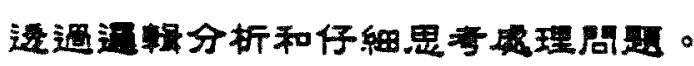

64.

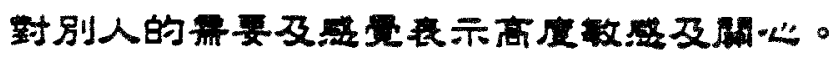

65. 經常锁服及影算他人。

66. 是個能弱譬别人的人。

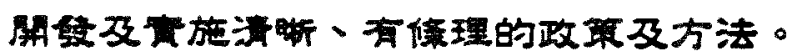

63.

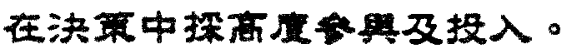

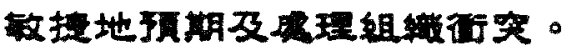
离度的提力及利造力。

67.

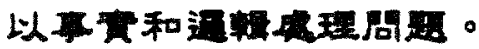

68.

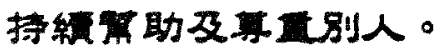

69.

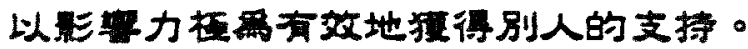

70.

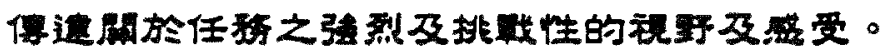

71.

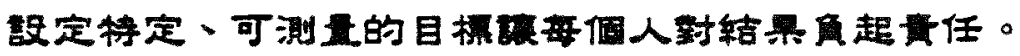

72.

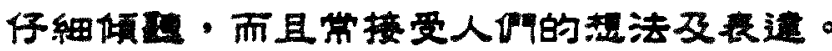

73. 在政治方面非裳数盛及熟綧。

74.

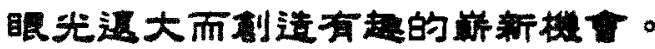

75. 非常注意細第。

76. 新把工作值好者給手個人的昭可。

77.

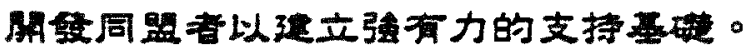

78. 引教虫酸度及整心。

79.

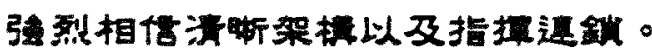

80.

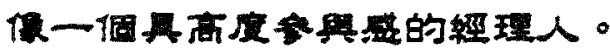

81. 成功地面璟行突及反璟。

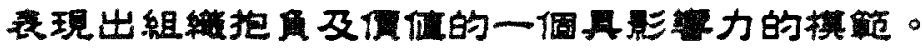


第82-87題請您描述您所評分者的領導型態。每個項目給” 4 " 表示對這 個人的最佳描述, “3”是次佳, 派減至"1" 表示最不符合這個人。

倒超敦明

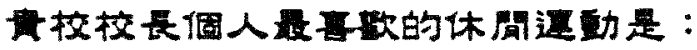

$\begin{array}{ll}\text { a. } & \text { 打球 } \\ \text { b. } & \text { 爬山 } \\ \text { c. } & \text { 游泳 } \\ \text { d. } & \text { 慢跑 }\end{array}$

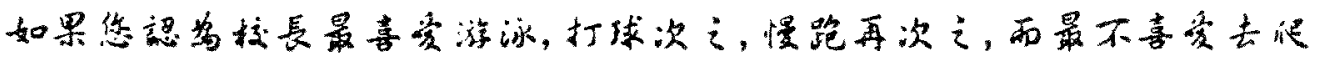
山。諳如下填答。

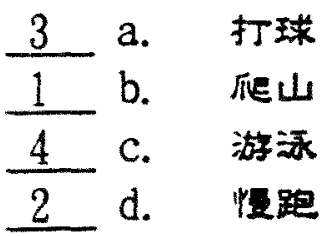

82. 典校校是最㢻的能力是：

— a. 分析船力

一 b. 人際的係的力

c. 政治餜力

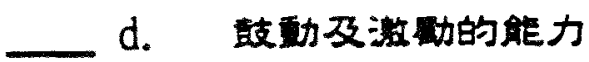

83. 每挍挍基的最佳描进是：

- a. 技街臬家

- b. 好的倾望者

- c. 有技巧的塧倜者

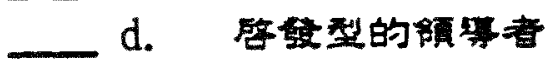

84. 策接挍县的最佳成就是：

a. 做好的決定

b. 剖練及培带人才

c. 建立有力的同盟及梅力基喽

d. 繁起及激勋别人 


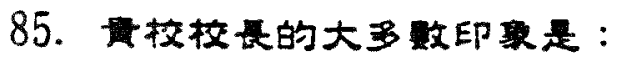
一a. 注意細第
- b. 解近別人

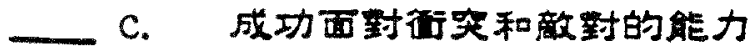
一 d. 卓越的领望解力

86. 莗校挍是最要要的領第能力是：

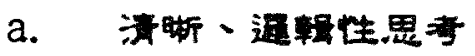

- b. 这及支持別人

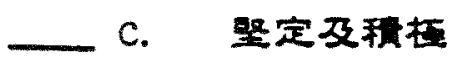

- d. 理力及剽造力

87. 然挍校最的最佳描进是：

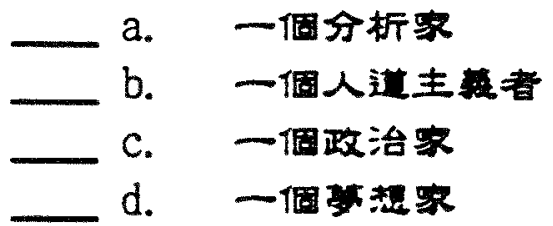

第 88,89 題是請您以整體表現(經驗和责任等)可比較的程度, 特貴校 校長與您所知的別人比較，您對貴校校長的評分是：

88.

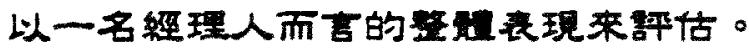

$\begin{array}{lllll}1 & 2 & 3 & 4 & 5 \\ \text { 低 } & & \text { 中 } & & \text { 高 }\end{array}$

89.

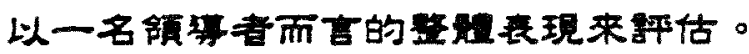

$\begin{array}{lllll}1 & 2 & 3 & 4 & 5 \\ \text { 低 } & & \text { 中 } & & \text { 声 }\end{array}$

*** 謝謝您的弯贵意見 $* * *$ 
November 25, 1957

Spring, 1985

Fall, 1990

$1979-1982$

$1982-1983$

$1983-1985$

$1985-1993$

$1992-1993$

1993
Bom: Taichung, Taiwan, R. O. C.

B.S.: Feng-Chia University

M.B.A.: Lindenwood College

Machine Maintenance

Sung Kung Industry Corp.

Taiwan, R. O. C.

Director of Manufacturing

Sung Kung Industry Corp.

Taiwan, R. O. C.

Business Manager

Sung Kung Industry Corp.

Taiwan, R. O. C.

General Manager

Sung Kung Industry Corp.

Taiwan, R. O. C.

Instructor

Chien-Kuo Junior College of Technology and Commerce

Taiwan, R. O. C.

Inventor of detachable visor for hooded raincoats Patent No. 103448, Republic of China 